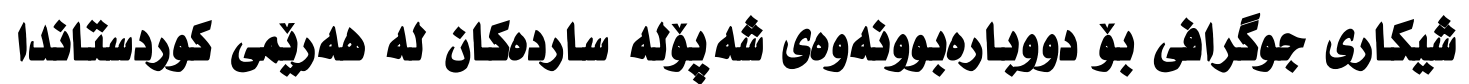 اله ماوهى ثيّوان (2017-2000)
}

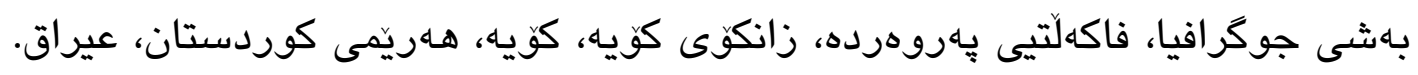
luqman.omer@koyauniversity.org
لوقمان وسو عمر

كيمهنيل: تونمان

محمد قادر رسوز

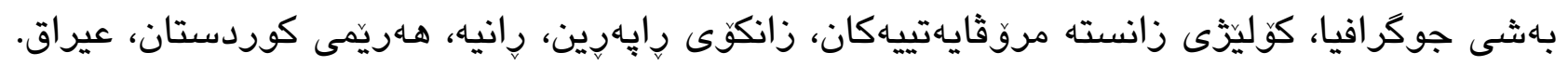

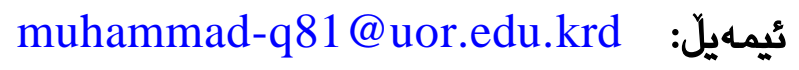

\section{يوخته:}

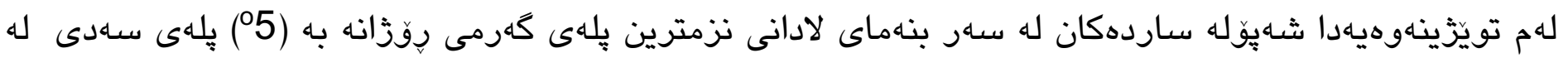

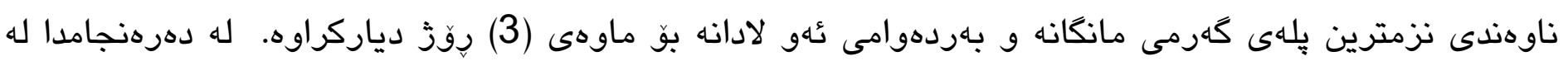

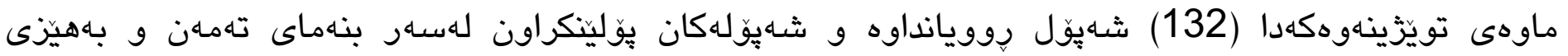

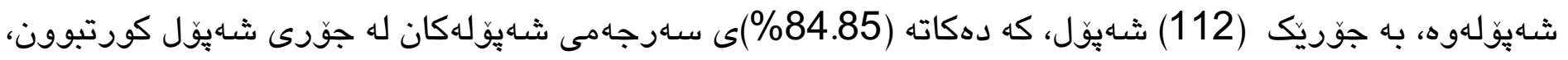

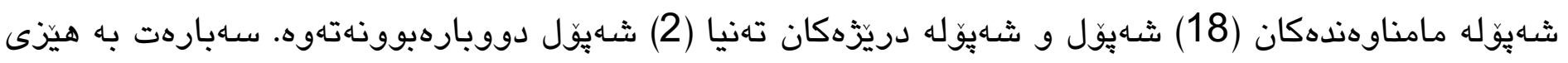

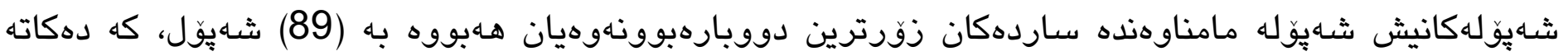

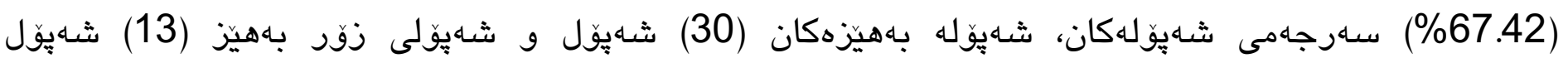

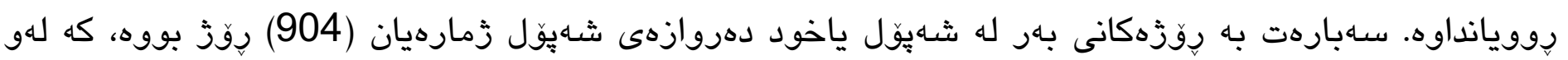

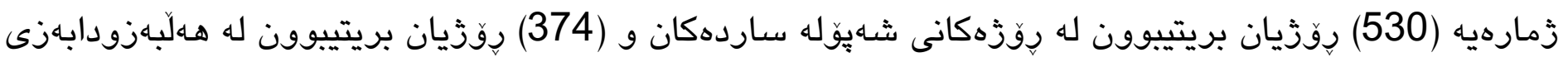

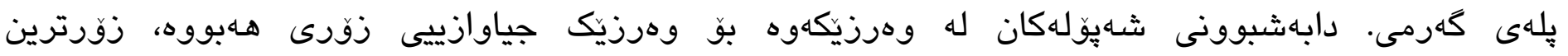

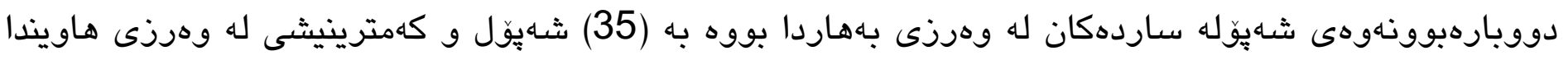

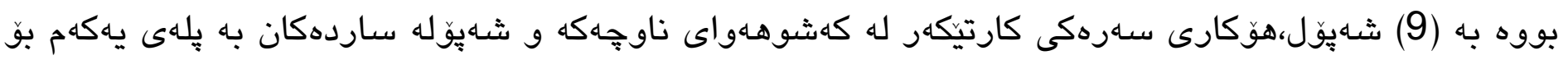

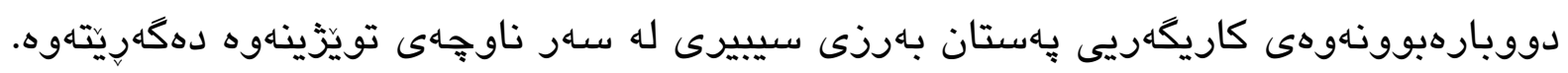

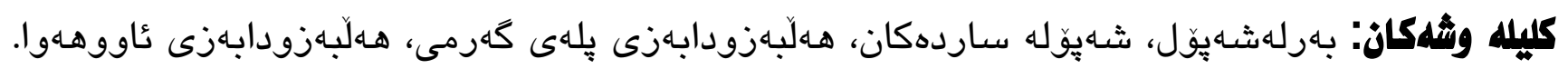




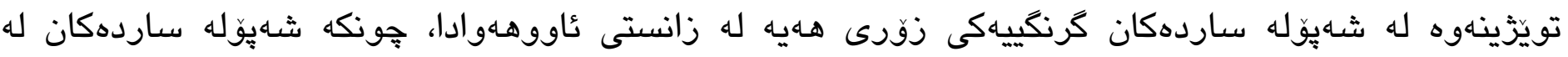

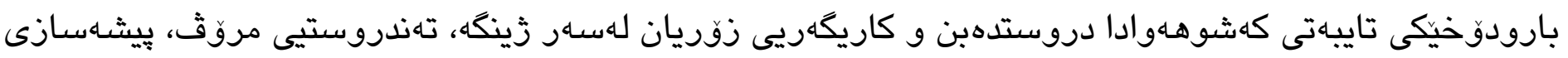

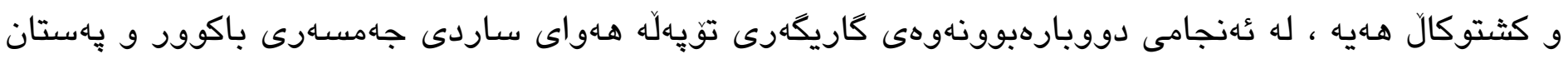

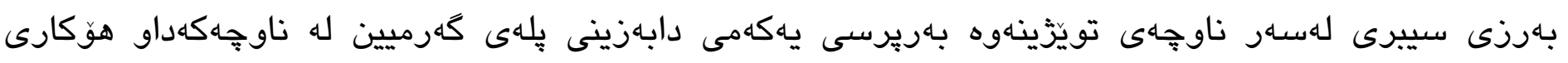

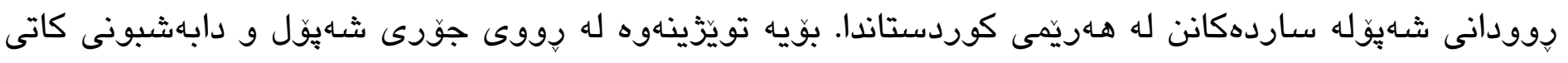

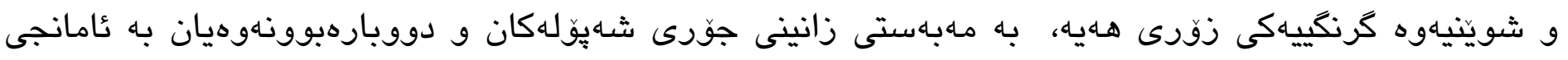

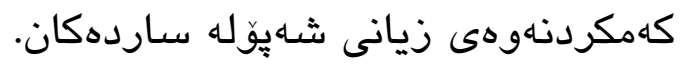

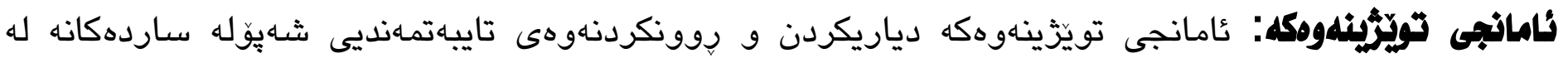

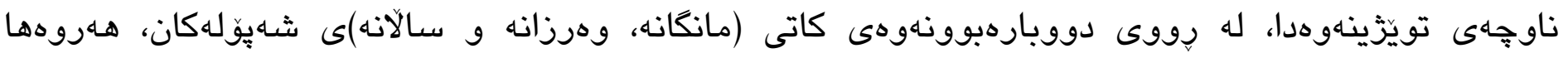

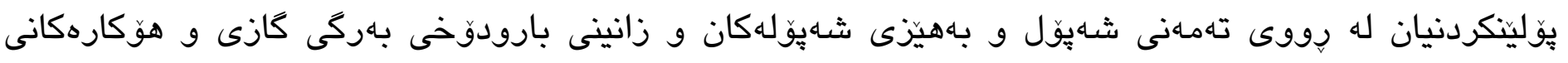

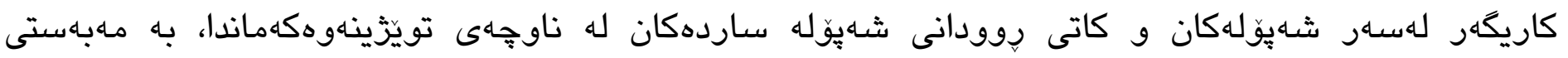

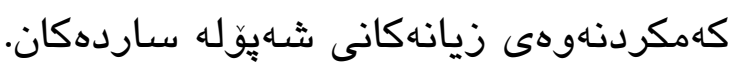

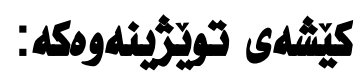

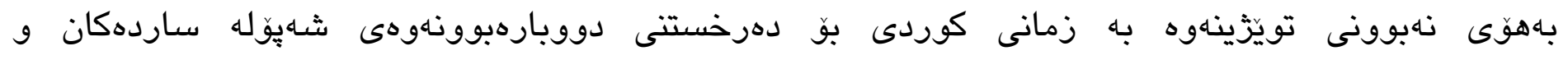

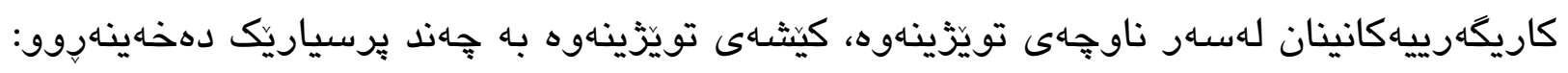

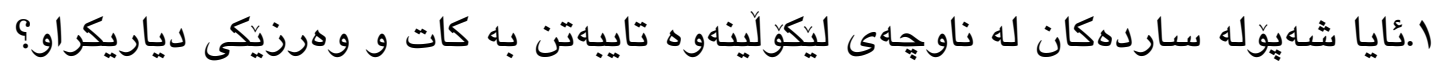

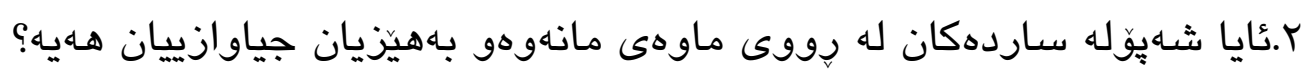

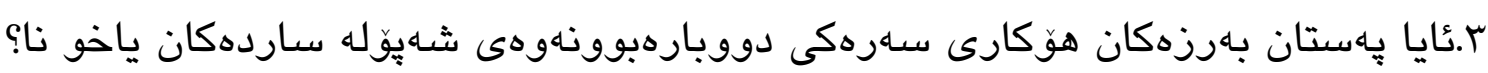

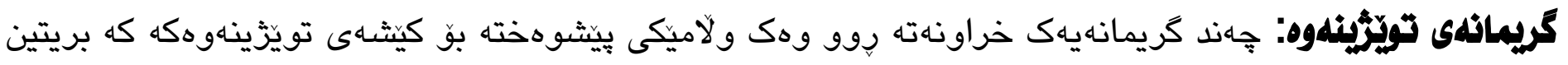
لهمانهى خوارهوه:

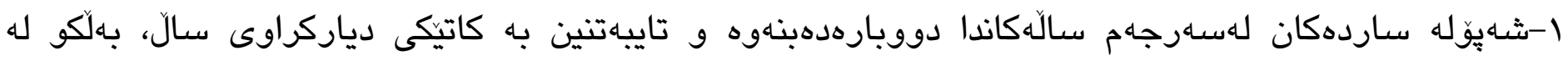

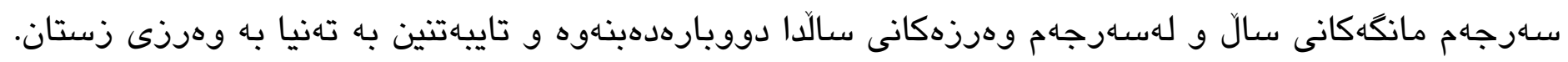

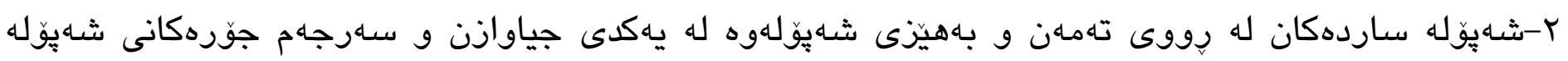

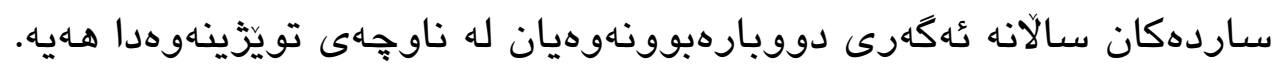

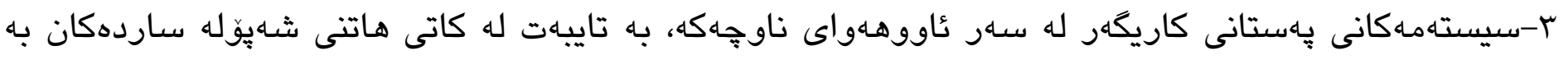

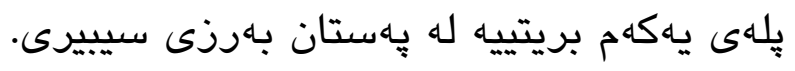

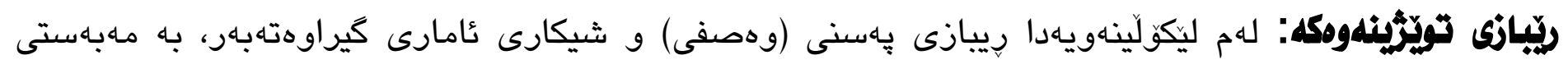

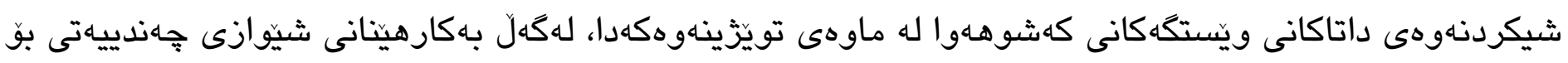

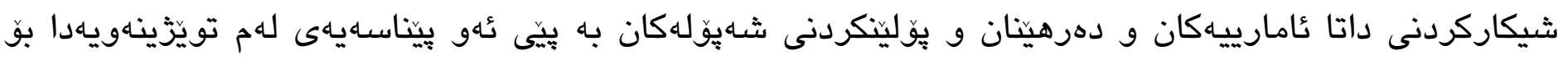
شـاهِولى سارد كراوه. 


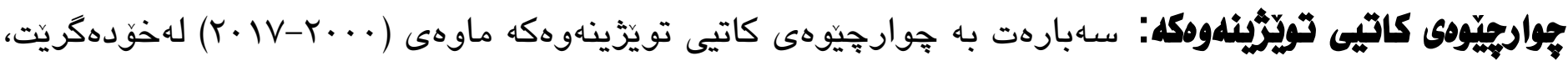

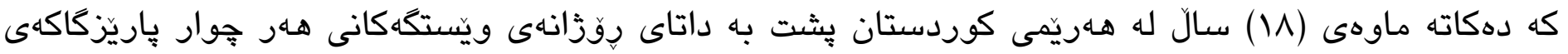

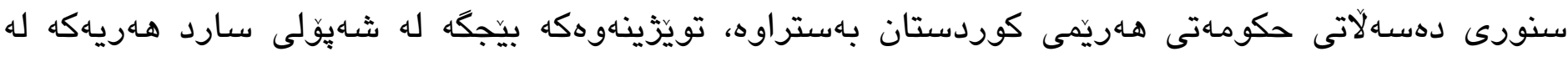

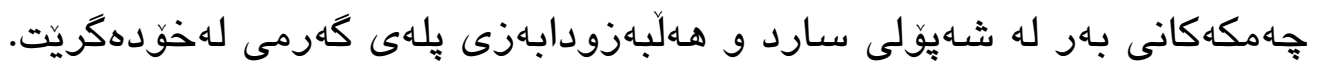

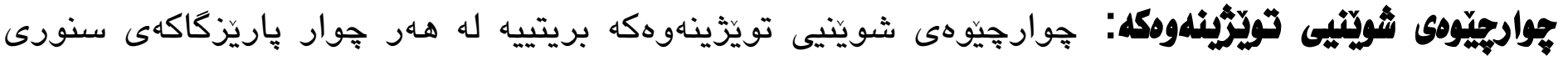

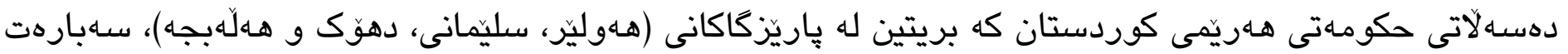

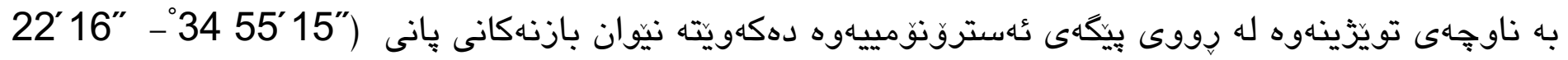

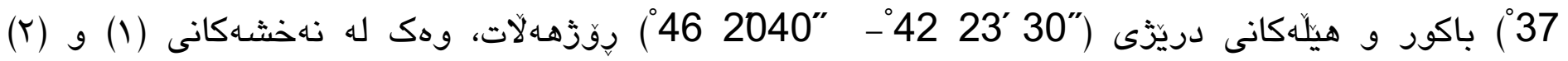
روونكراوهتهوه.

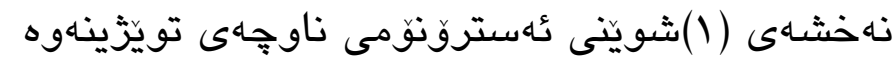

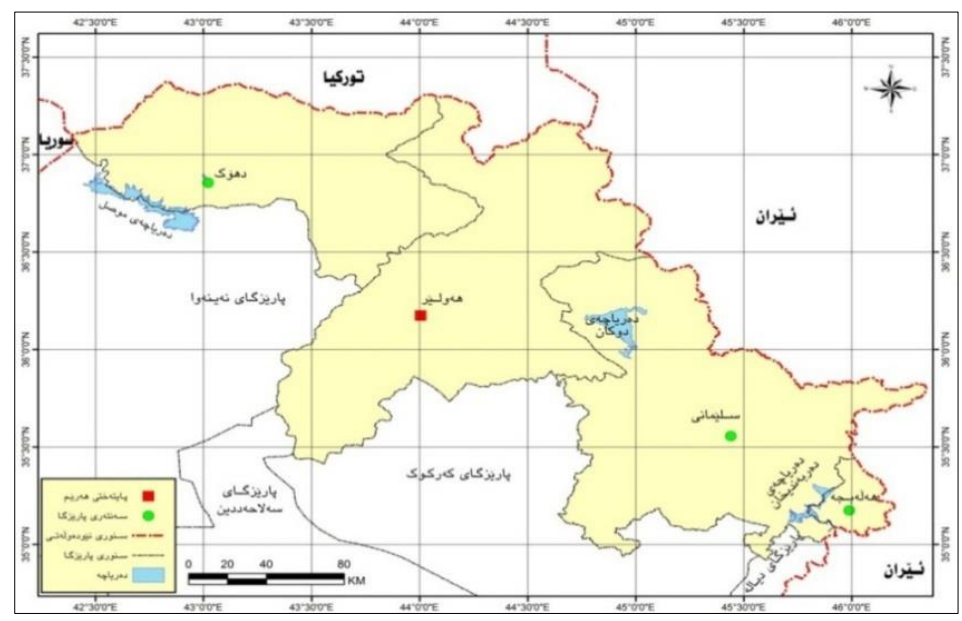

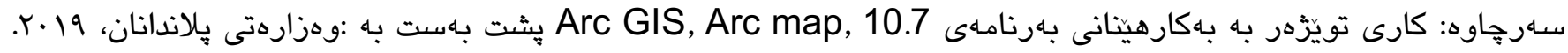

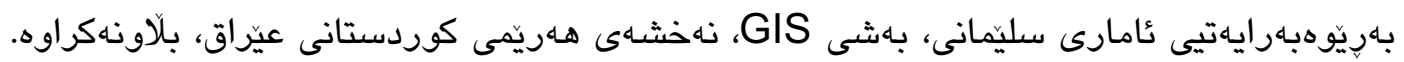

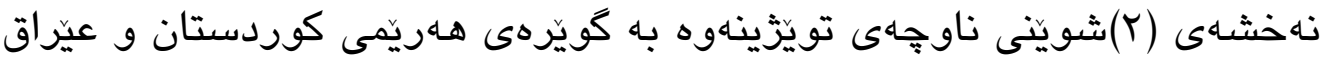

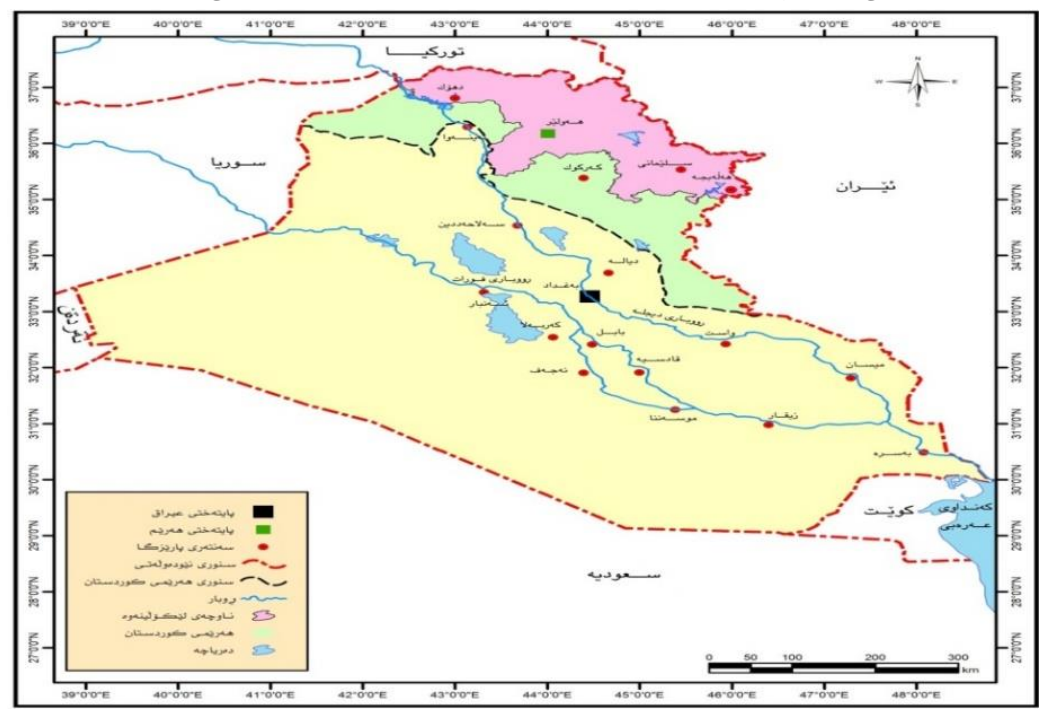

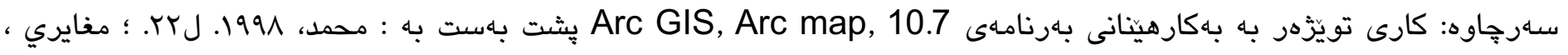

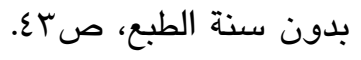




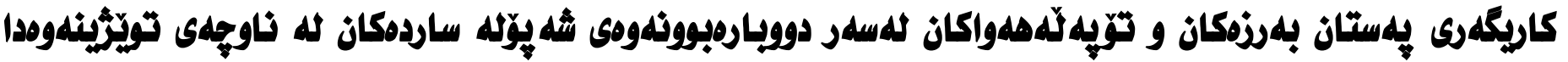

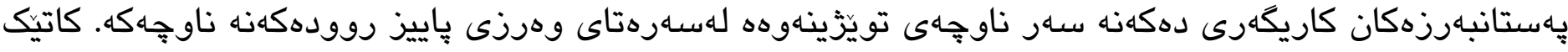

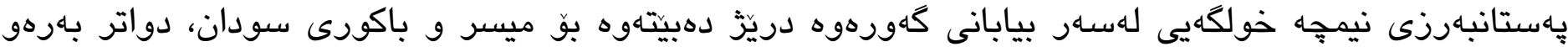

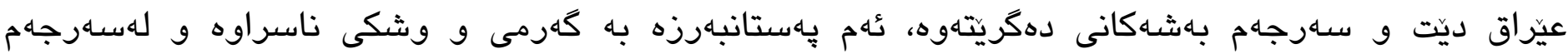

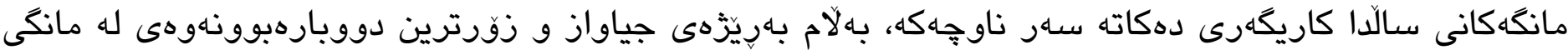
نيساندايه، له وهرزى زستاندا له مانكاكانى كانوونى يهكهم، كانوونى دووهم و شوباتدا يهاهتانبهرزى ئازقورى

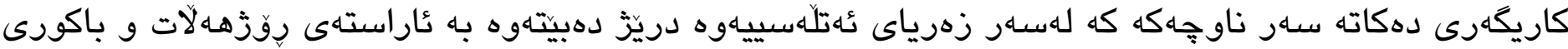

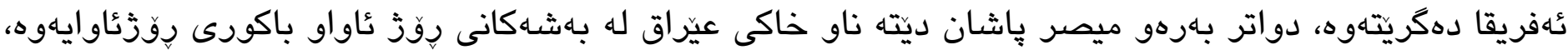

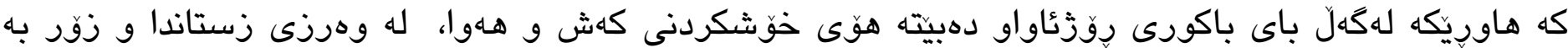

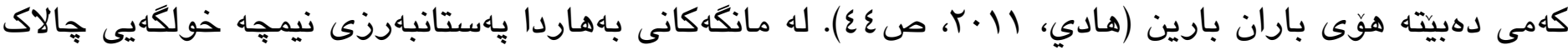

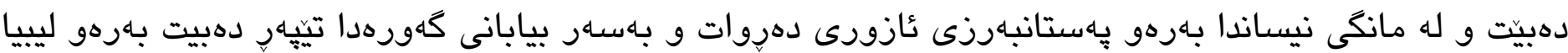

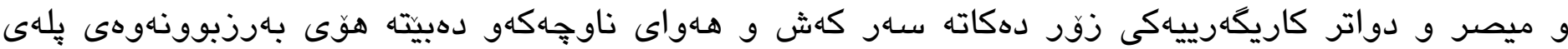

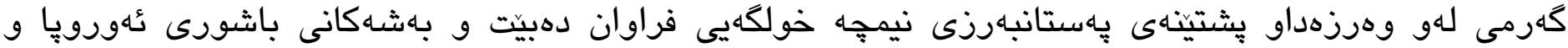

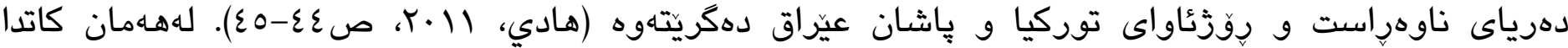

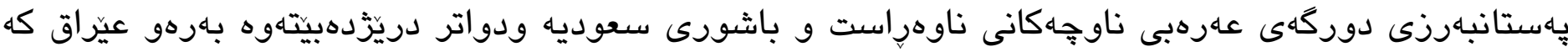

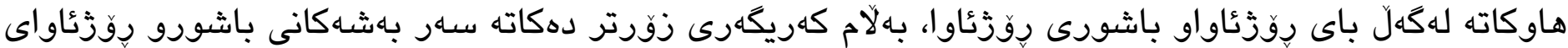

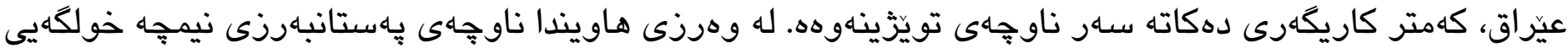

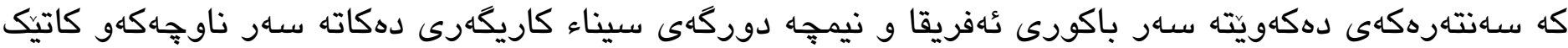

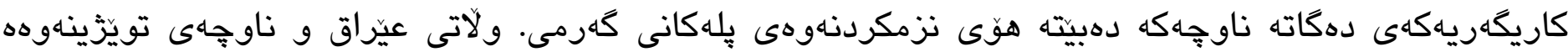

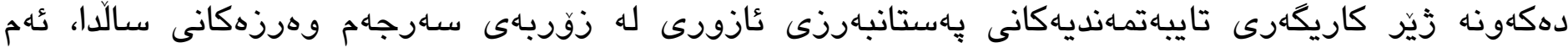

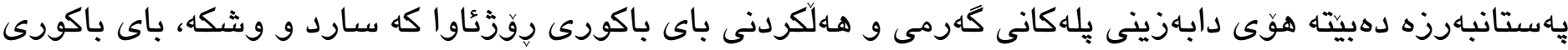

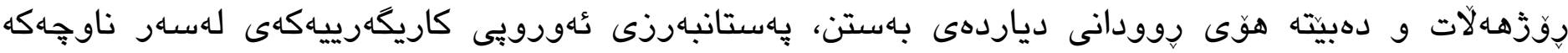

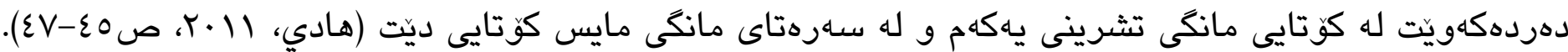
يهاستانبهرزى سيبرى كه تايبهتمـانديهكهى بريتييه له ساردى و وشكى دهبيته هوَى دابهزينى يله

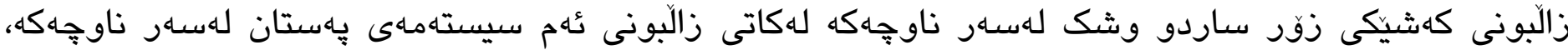

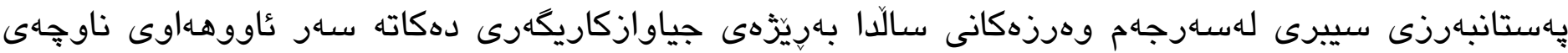

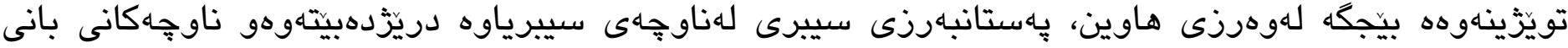

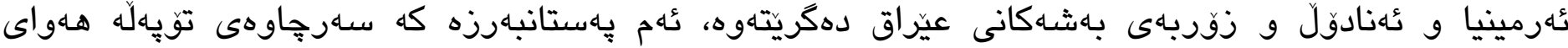

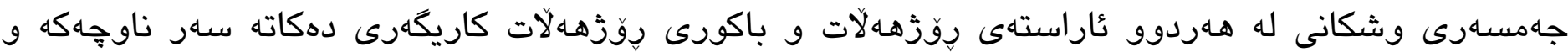

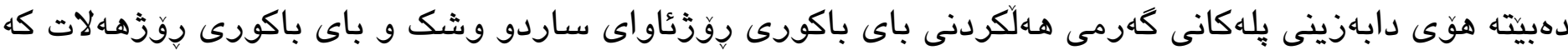

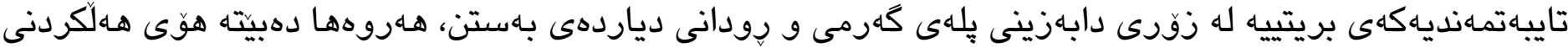

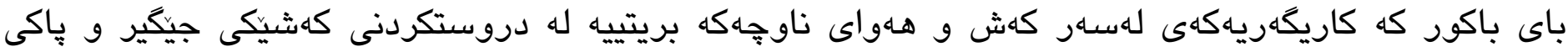

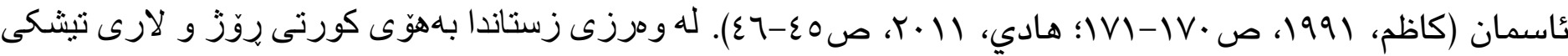




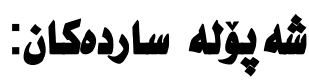

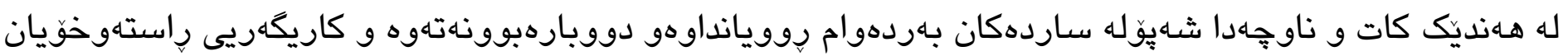

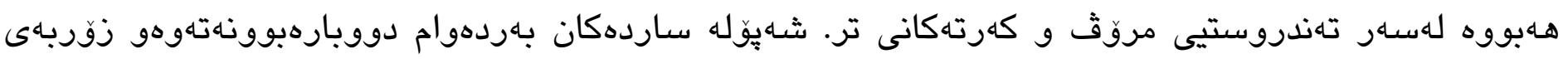

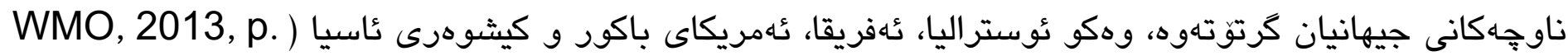

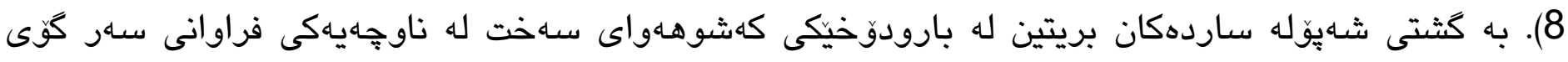

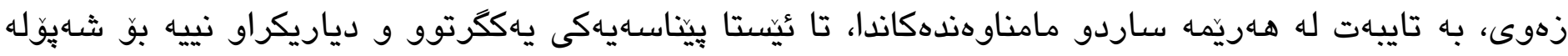

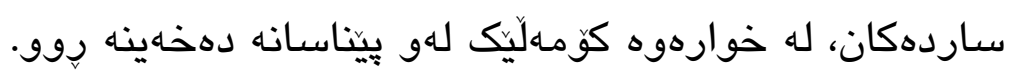

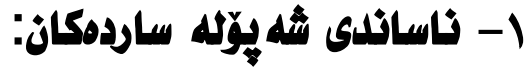

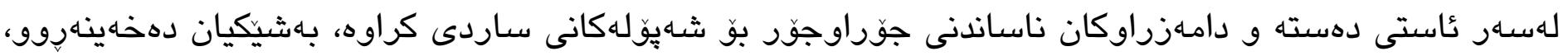

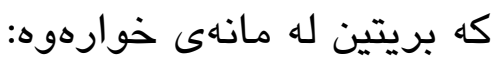

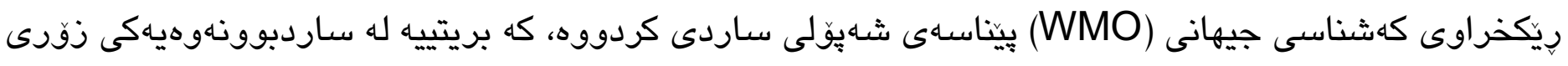

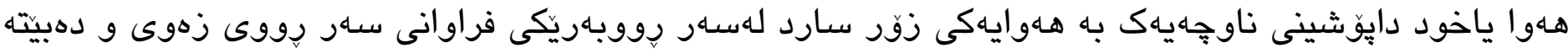

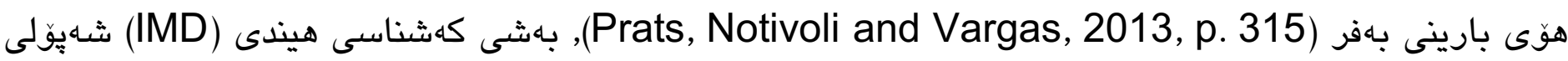

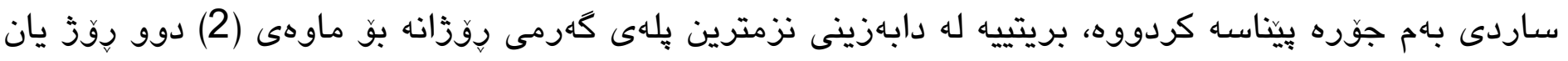

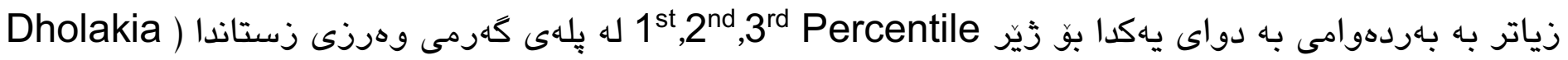
داوه، دand Garg, 2014, p. 5

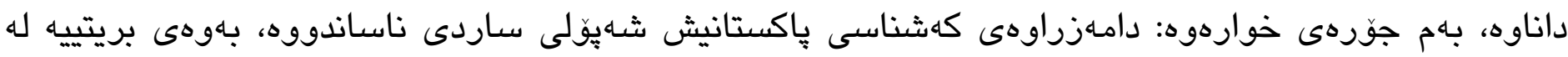

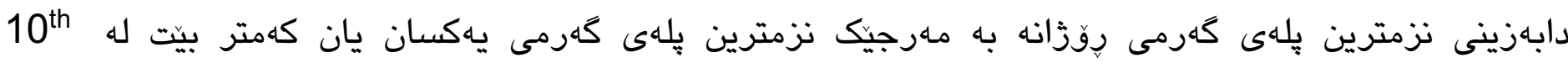

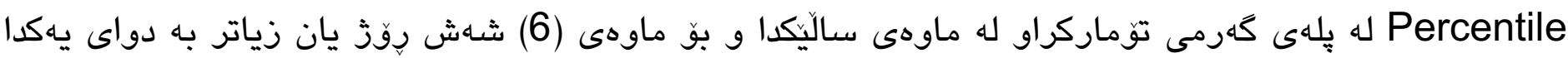

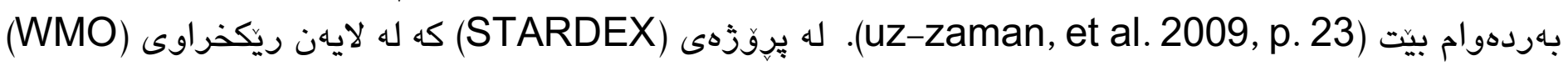

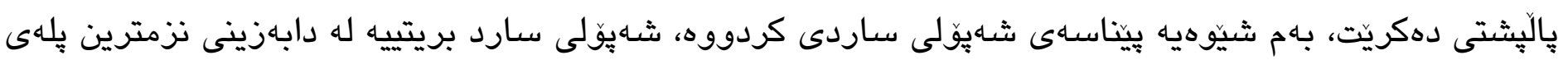

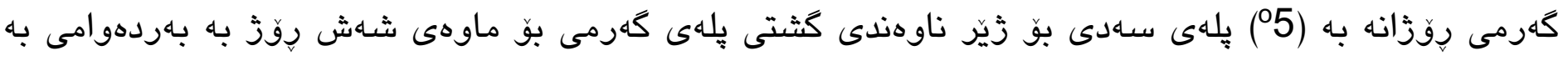

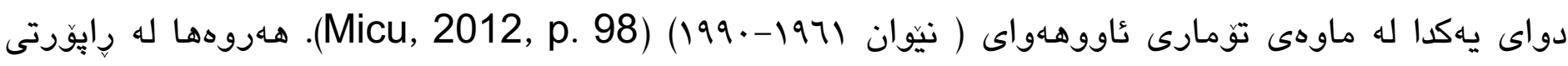

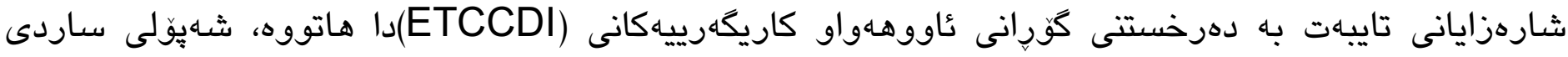

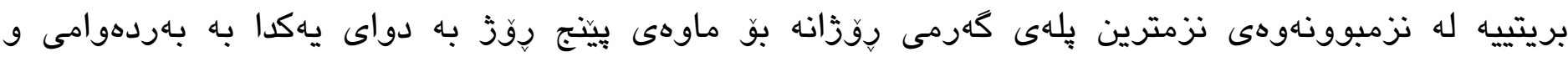

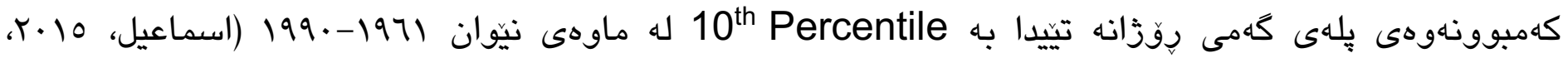

ص ص (T⿱宀⿻三丨

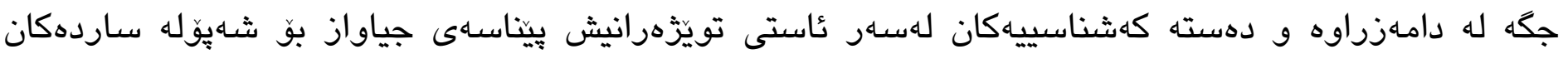

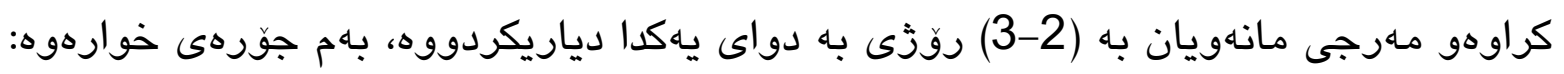




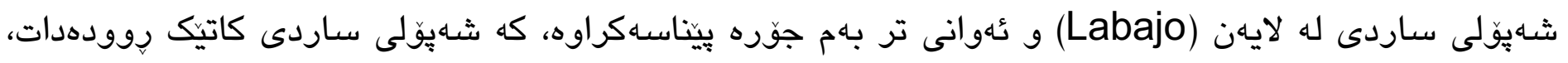

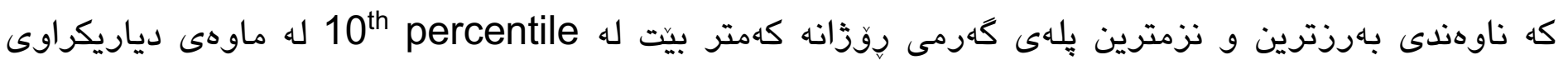

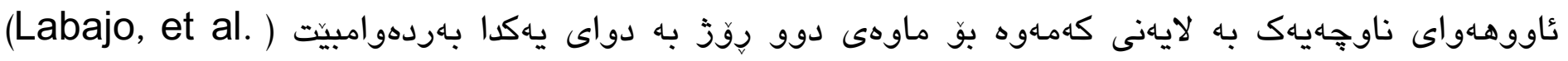

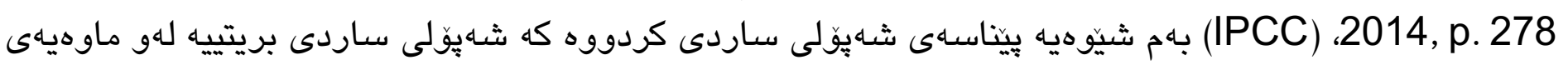

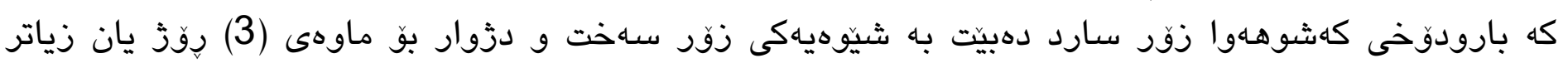

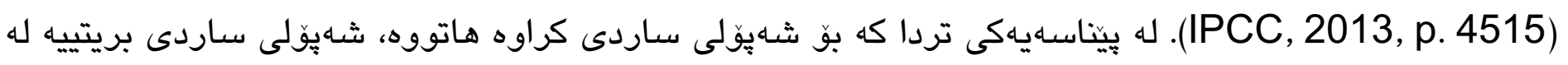

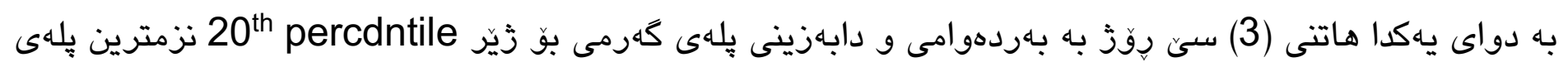

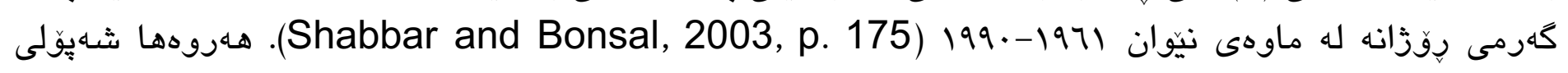

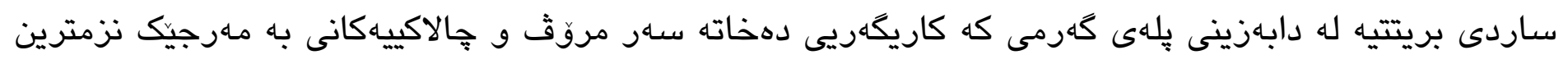

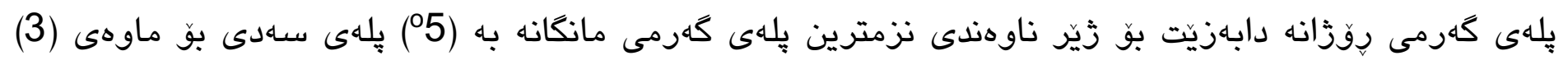

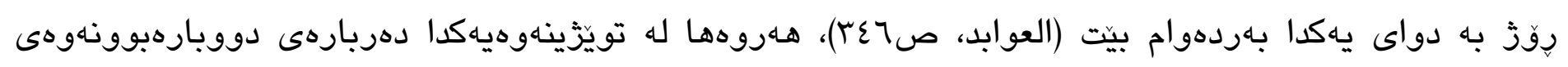

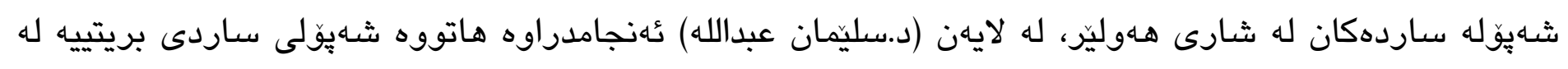

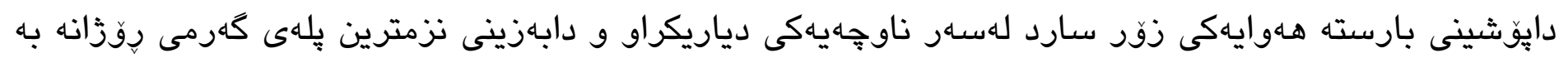

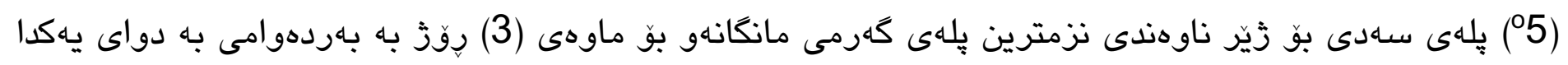

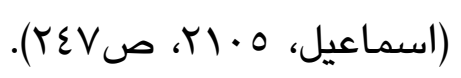

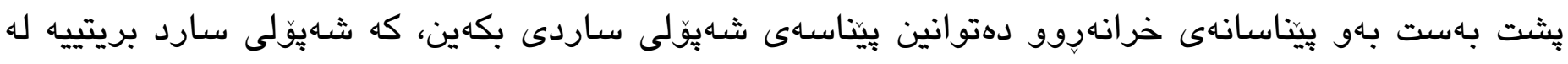

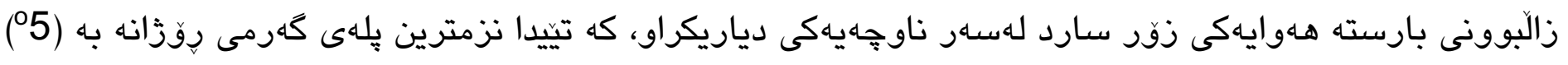

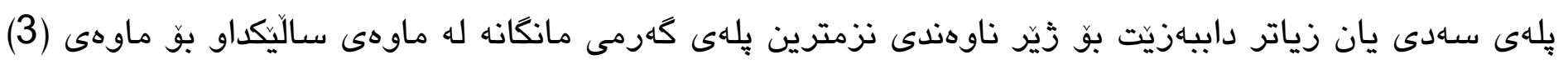

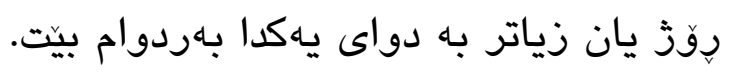

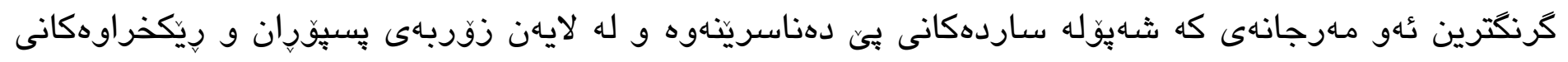

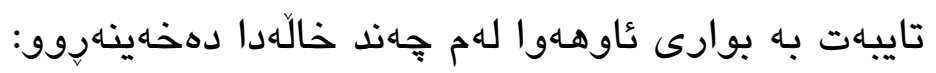

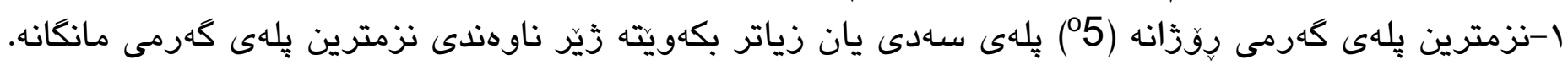

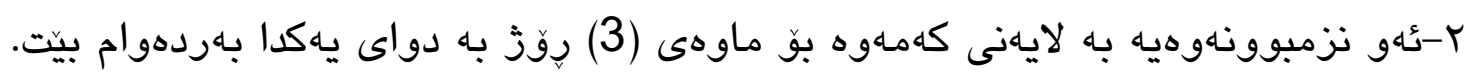

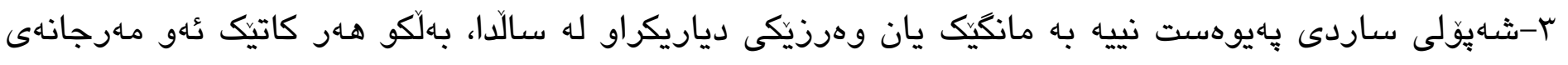

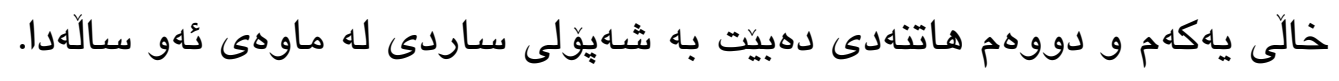

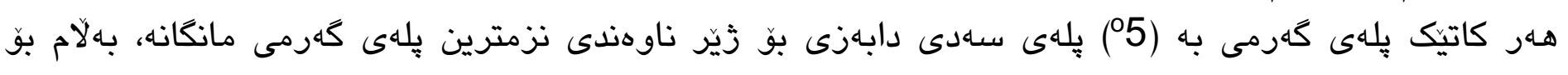

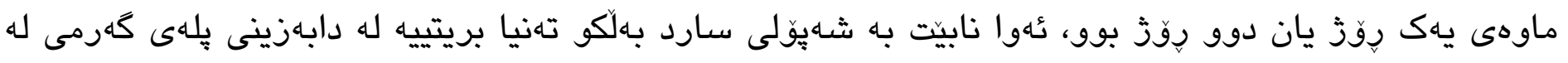

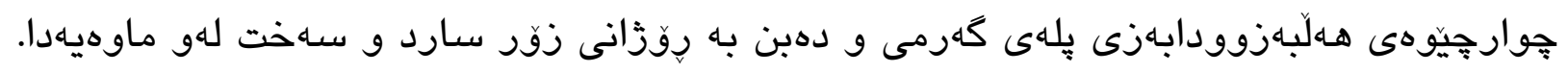

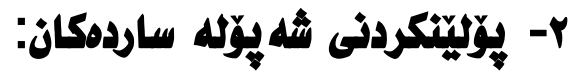

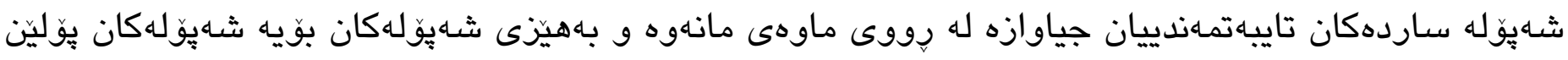

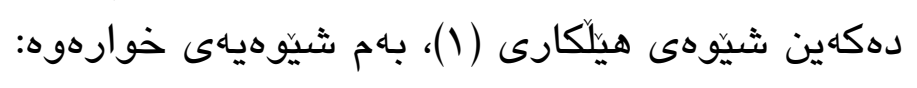

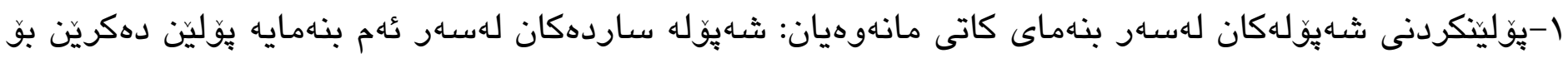

ئهم جوَرانهى خوارهوه: 
Journal of University of Raparin $\quad$ كوَّقارى زانكوّى رابِهرين

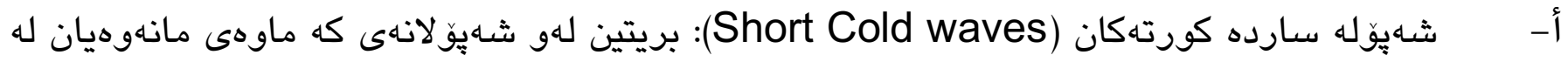
نيّوان (3-5) رِقَّدايه.

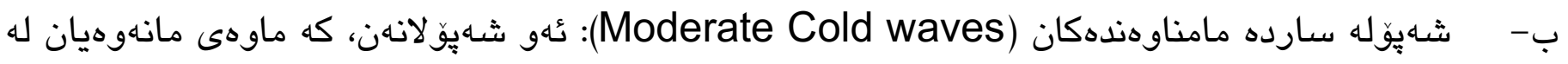
نيّوان (6-8) رِوَذدايه.

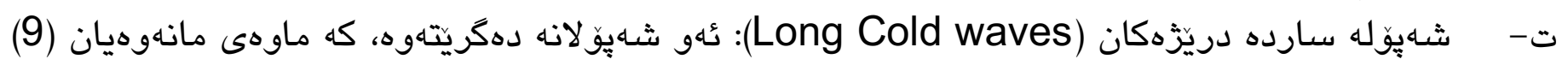
رِقَّ و زياتره.

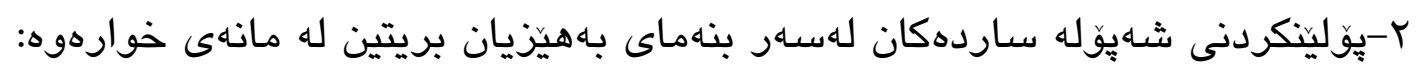

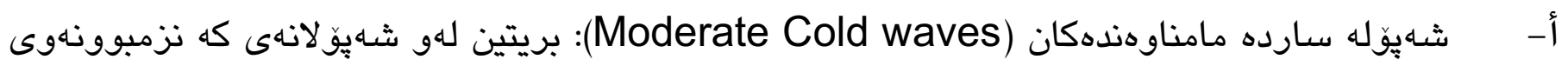

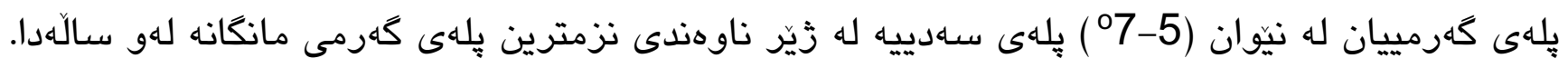

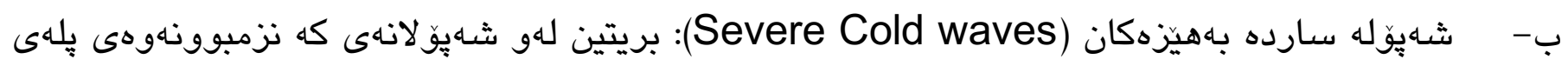

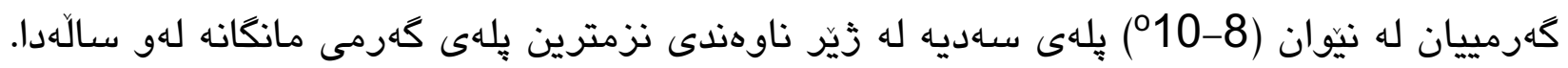

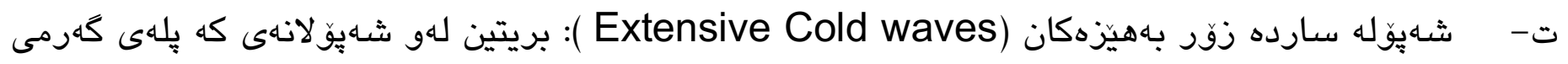

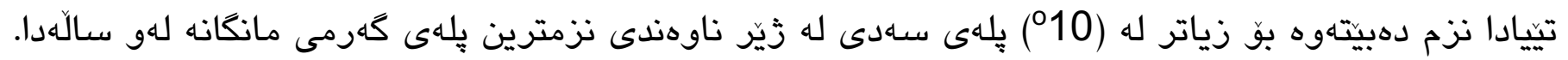

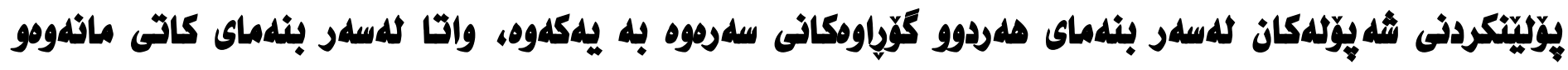

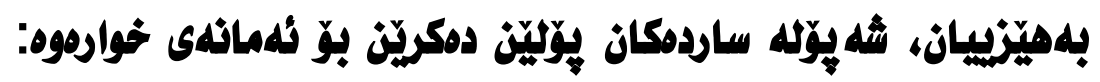

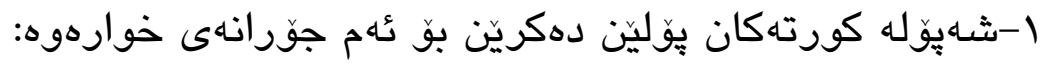

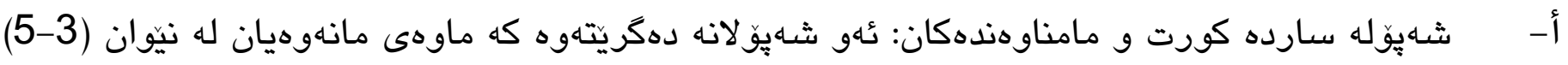

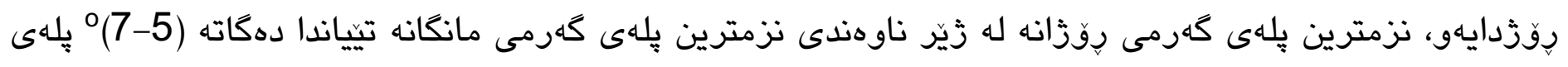
سـاهנى

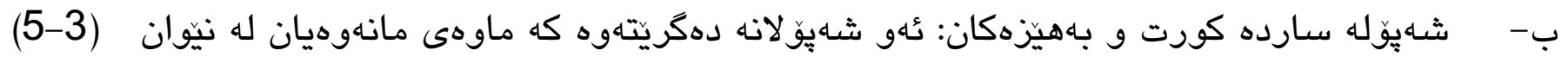

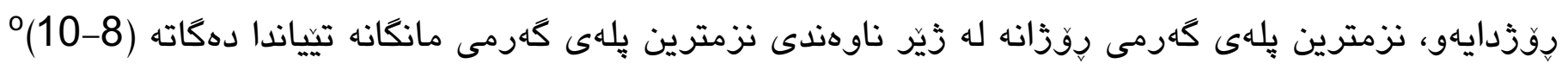
يله سله سهدى.

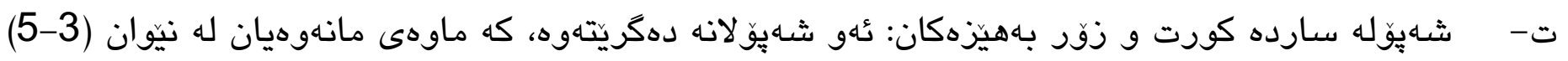

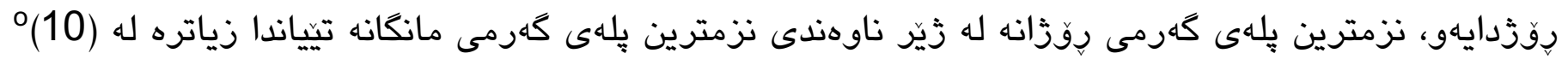

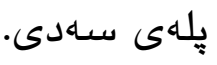

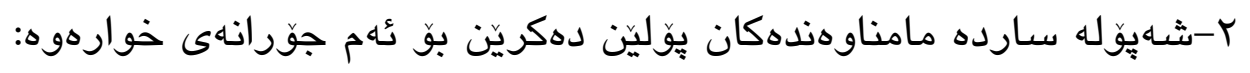

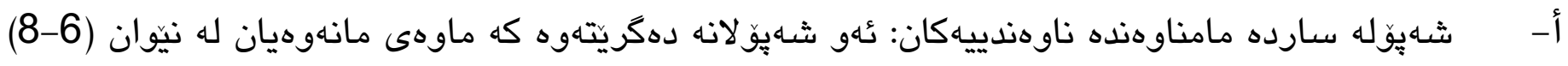

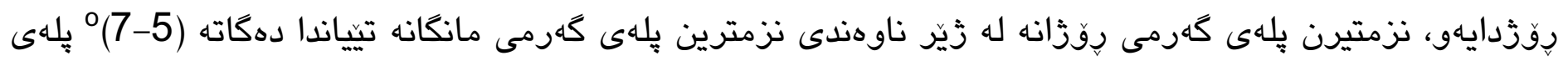
سـادى.

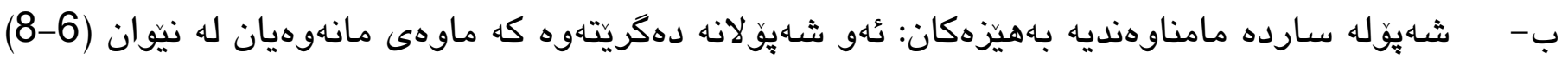

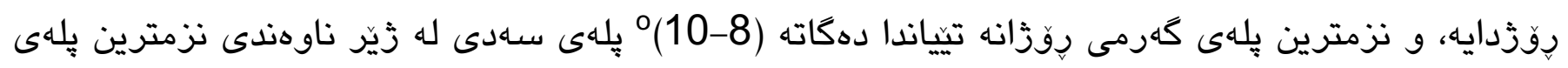
كهرمى مانكانه 


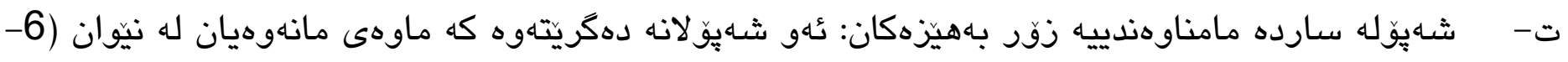

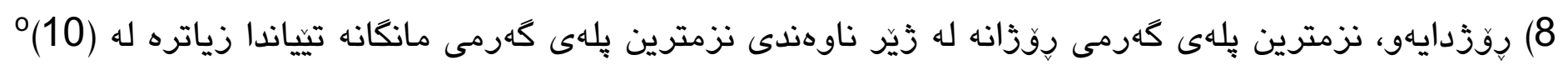

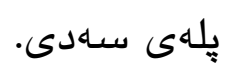

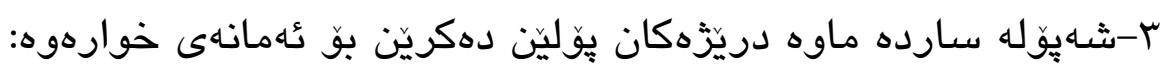

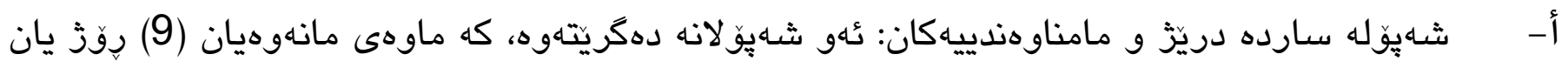

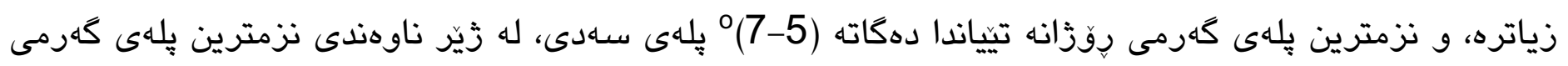
مانكانه.

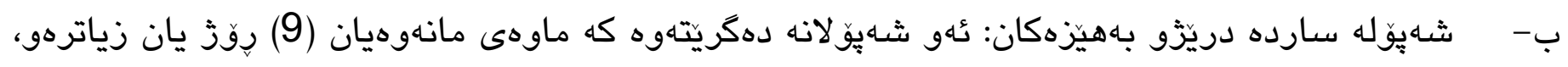

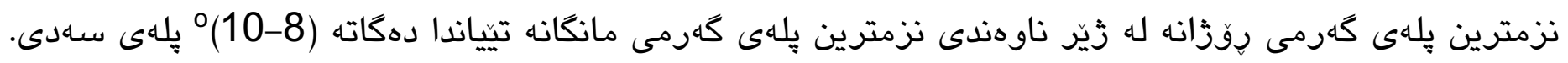

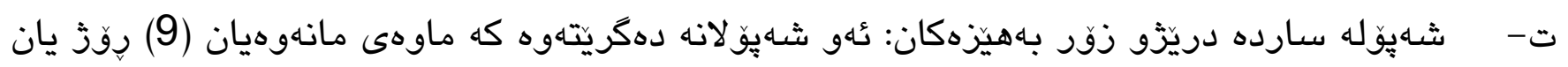

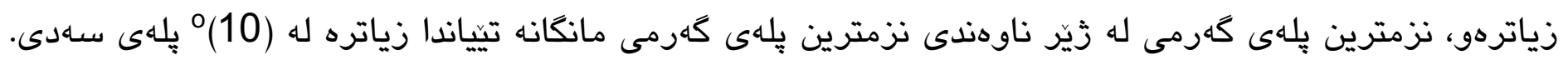

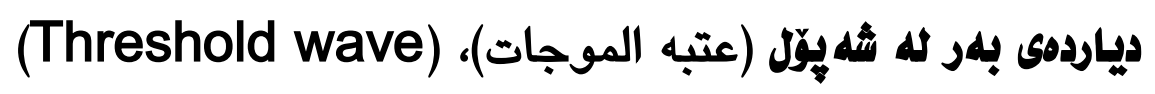

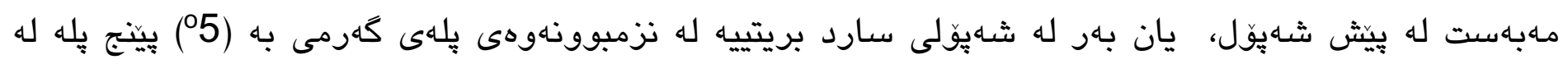

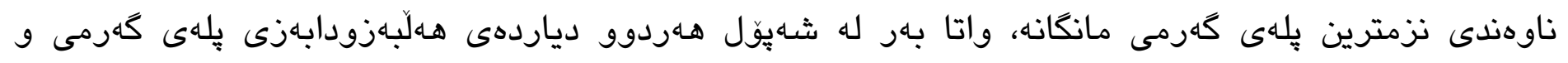

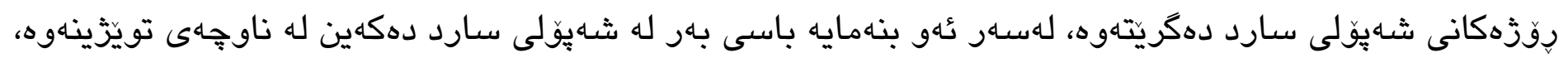
له ماوهى تويّزينهوهكهدا.

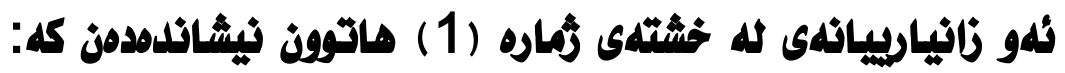

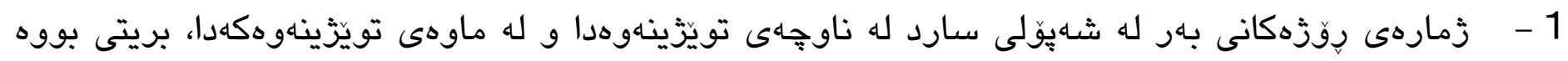

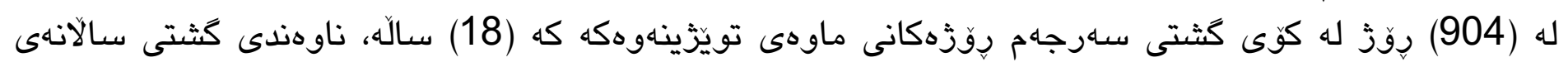

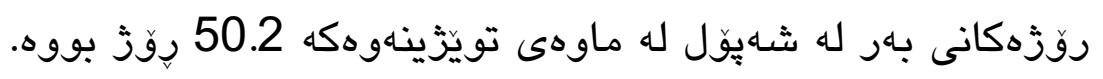

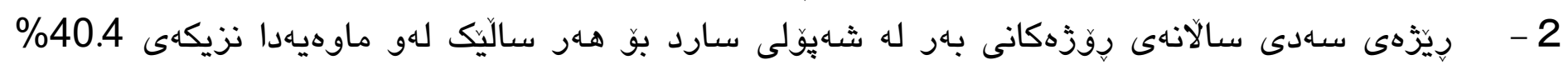
بووه.

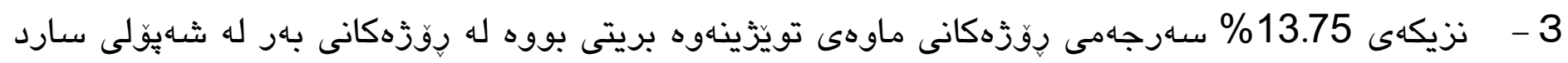
له ماوهى تويَزْينهوهكهدا.

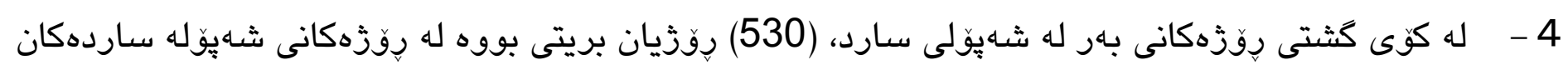

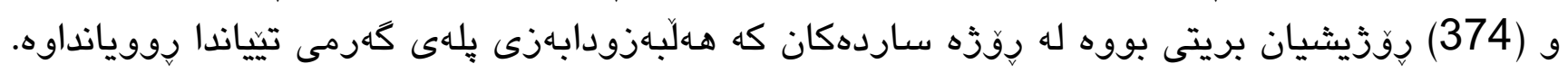

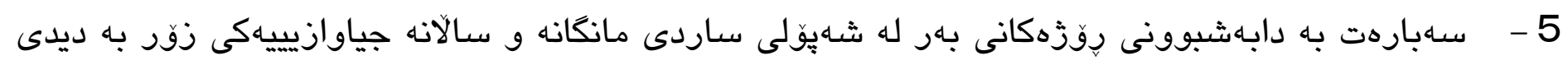

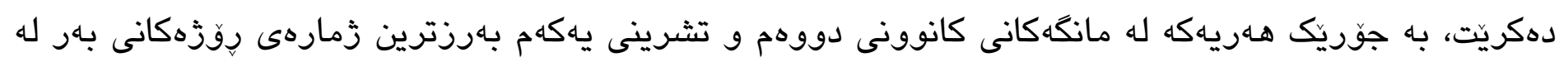

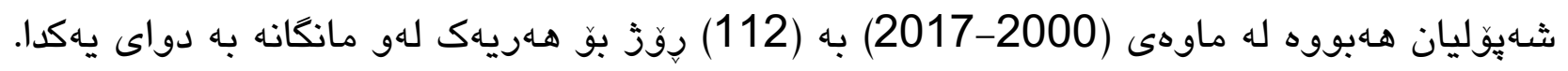

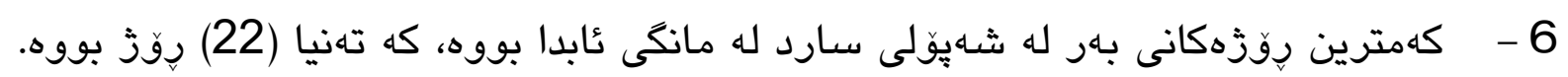




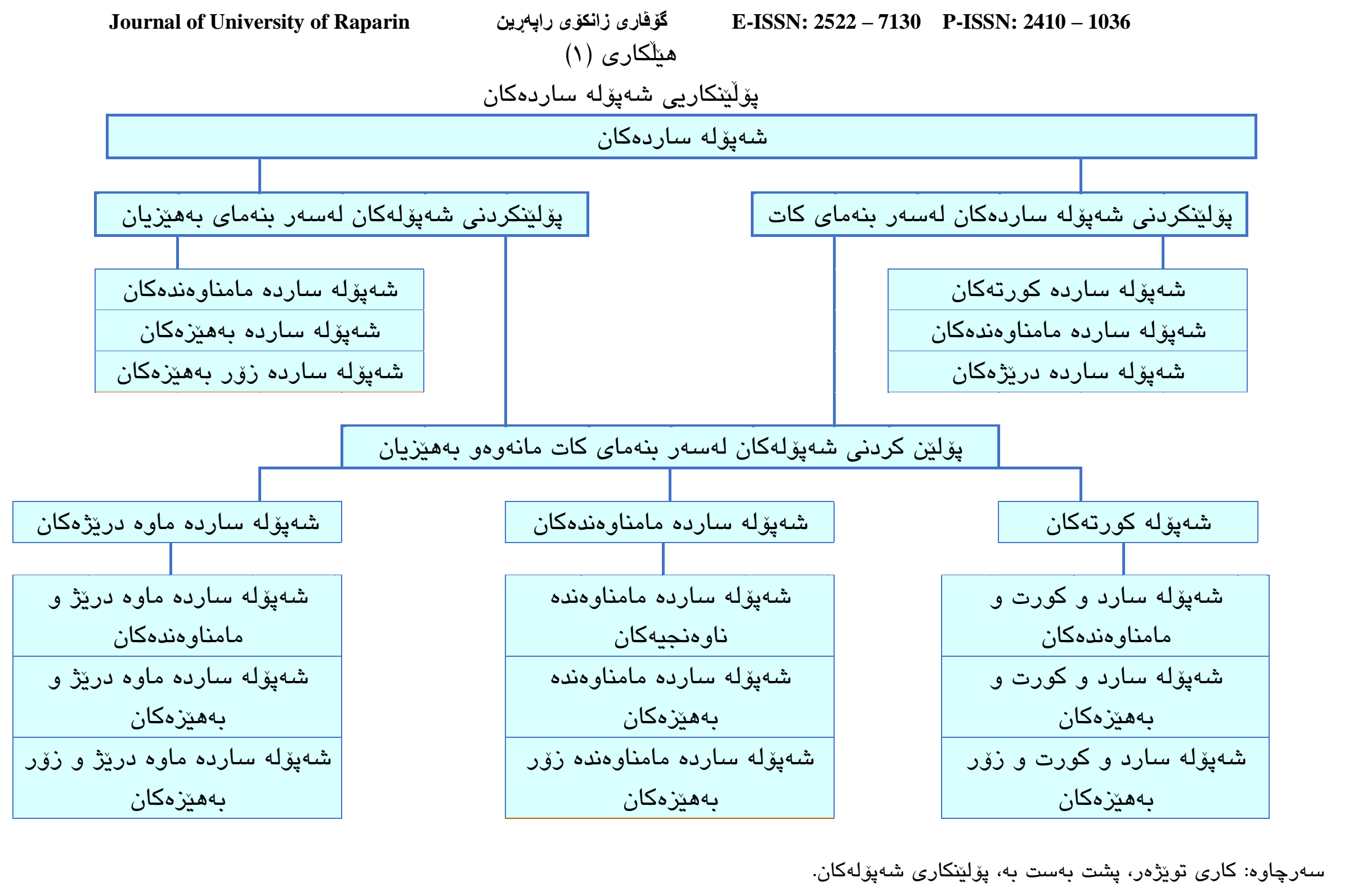




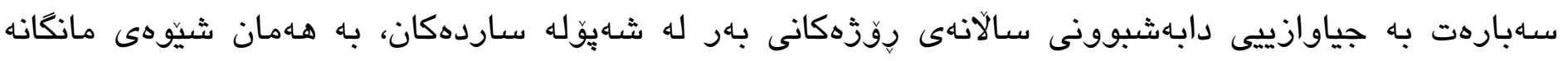

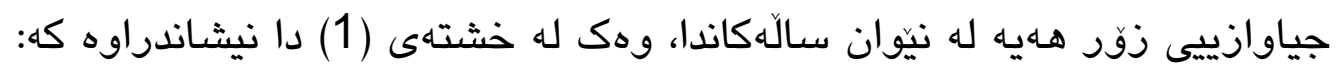

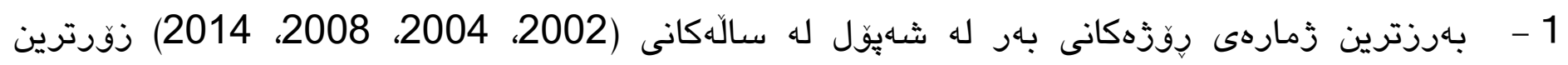

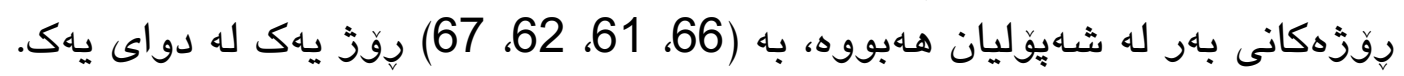

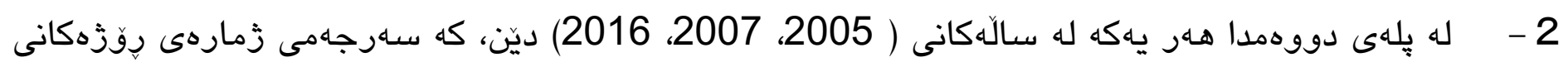

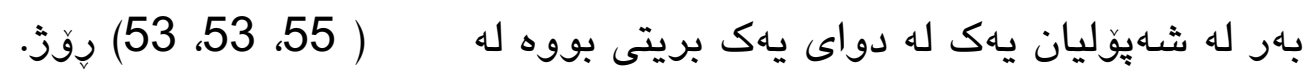

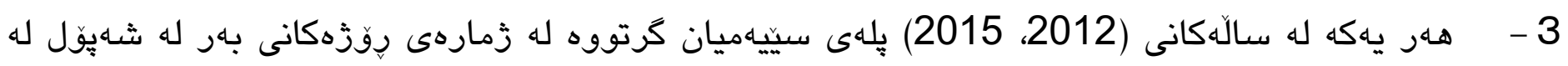

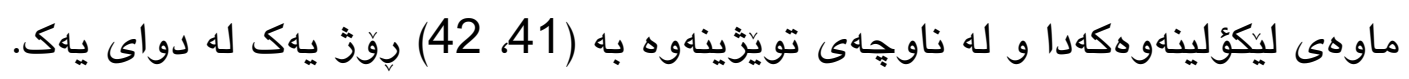

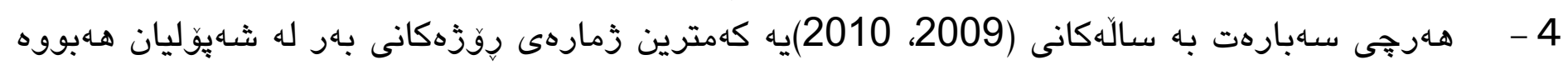

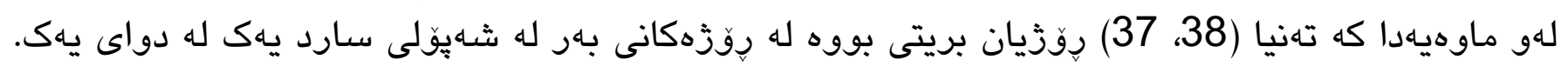

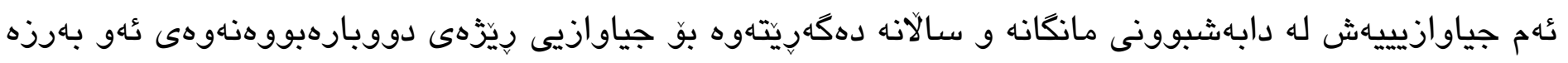

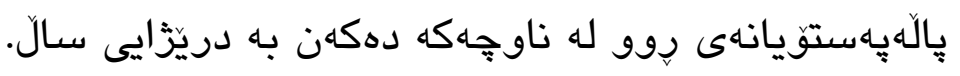

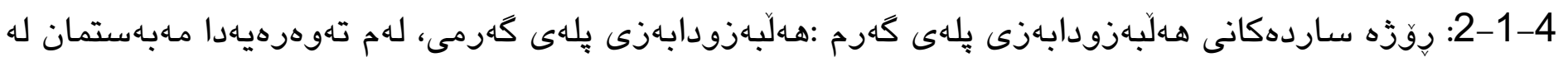

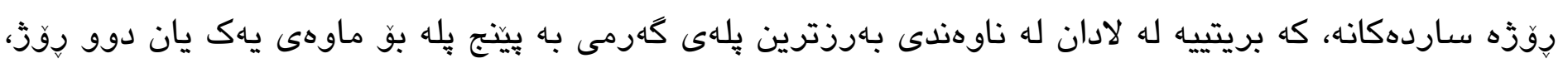

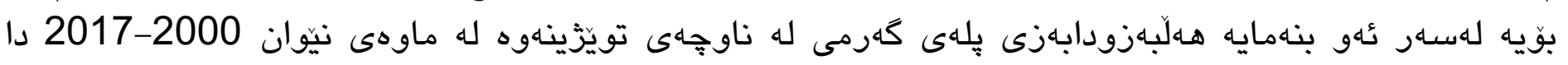
رووندهكهيناهوه.

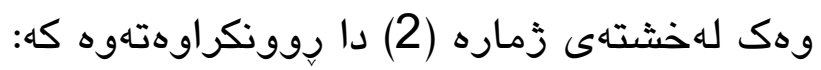

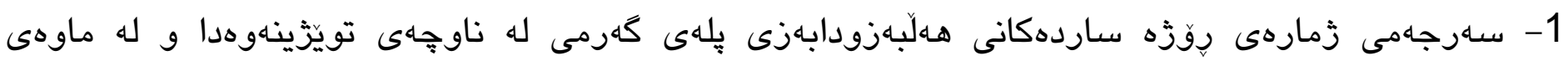

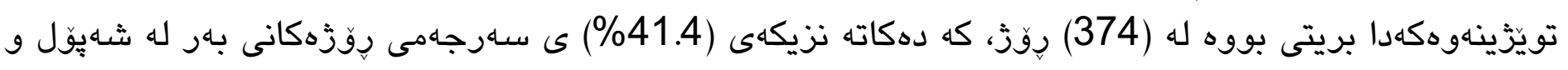

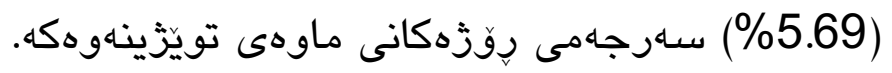

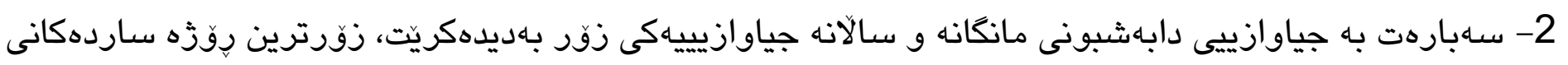

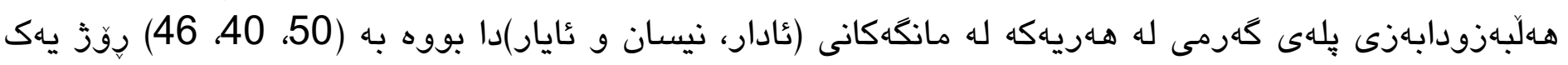

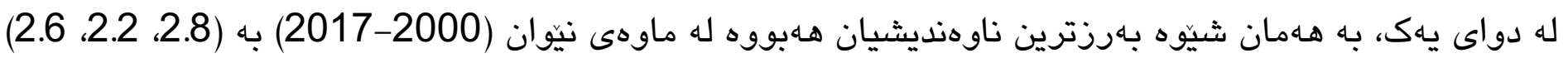

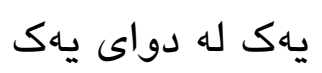

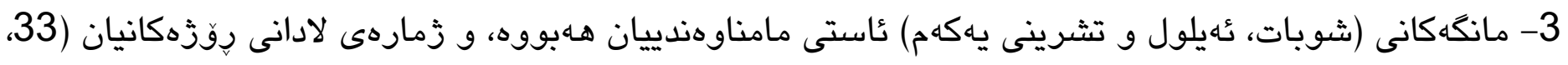

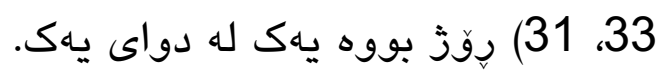

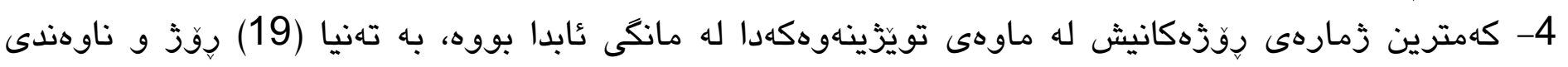

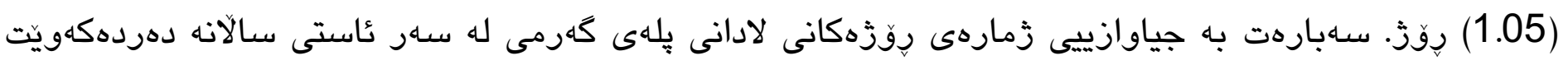
كه:

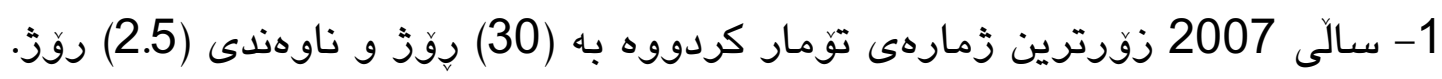

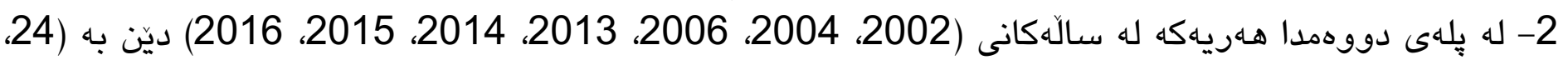

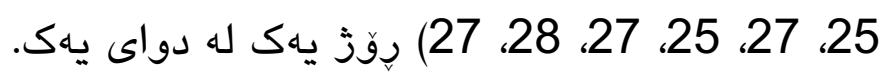




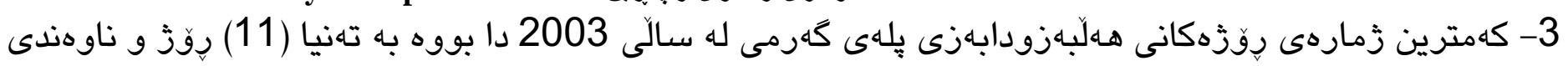
0.92

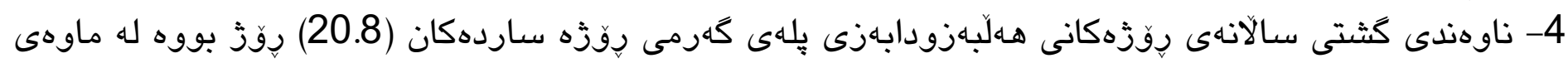

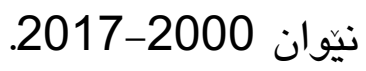

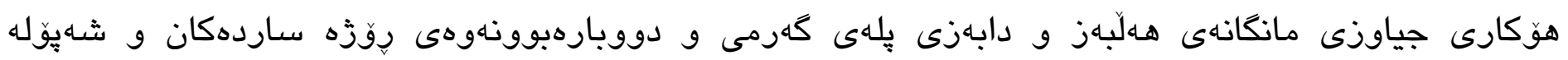

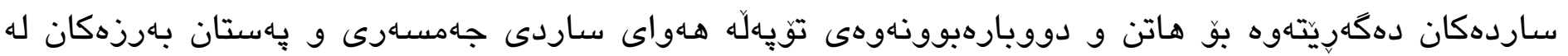

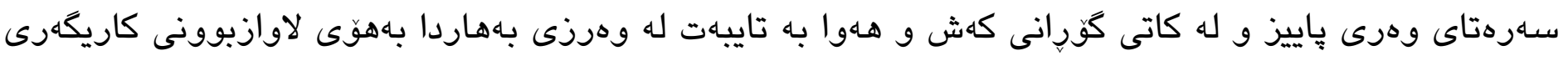

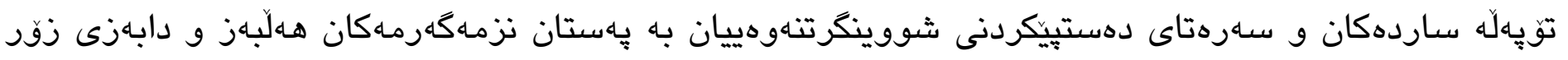

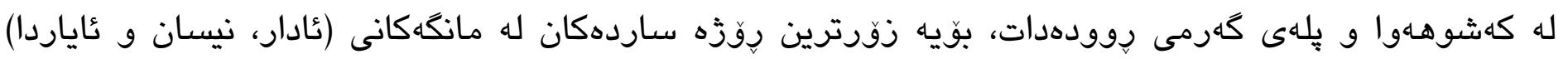
توَمار دهكريَن.

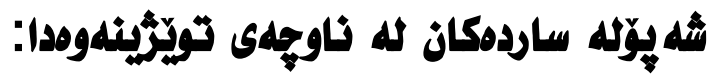

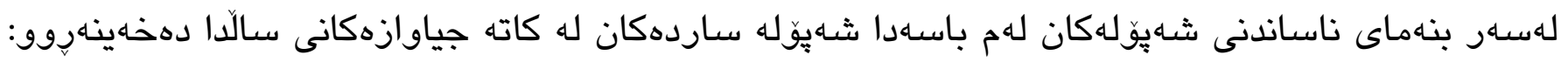

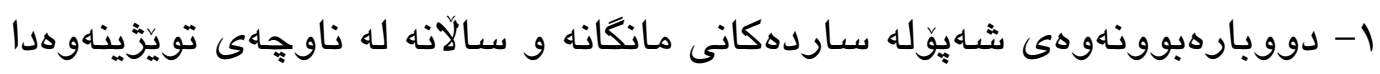

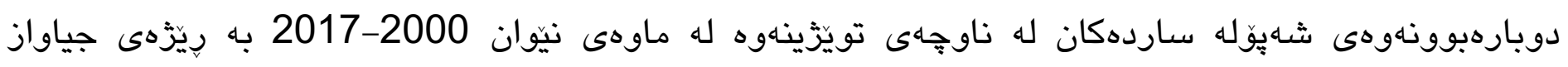

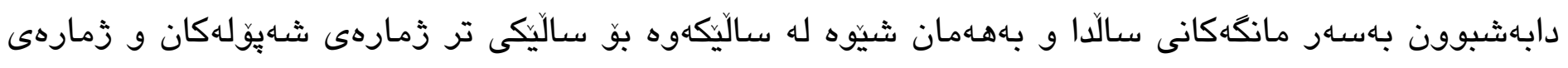

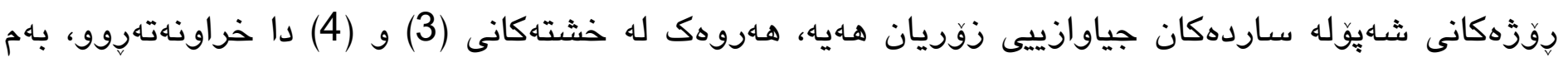

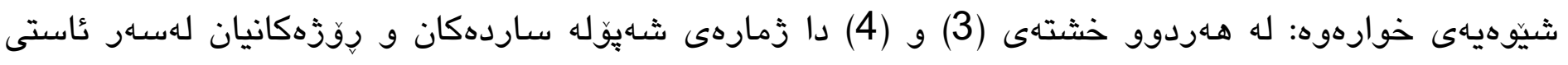

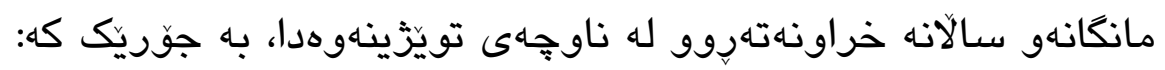

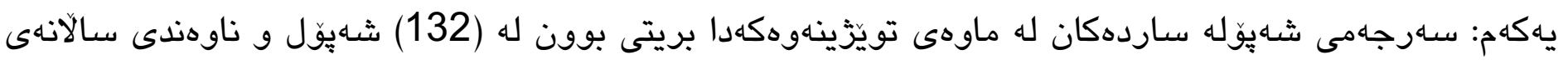

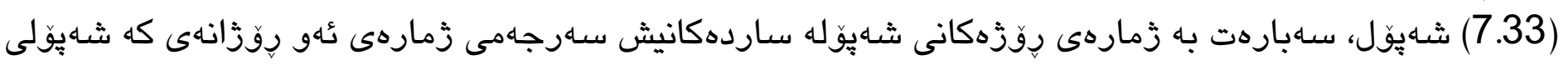

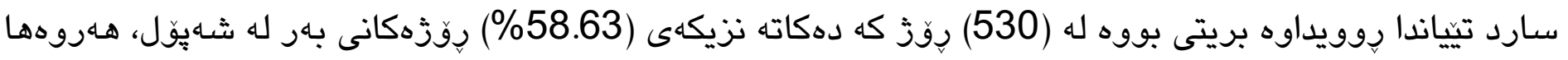

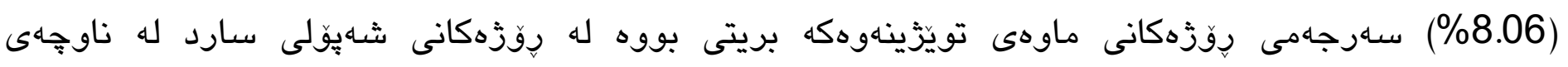
تويّزينهوهدا.

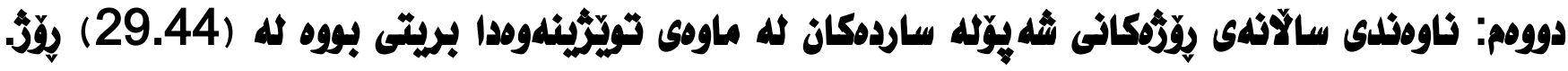

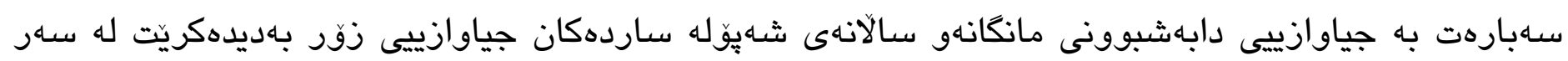

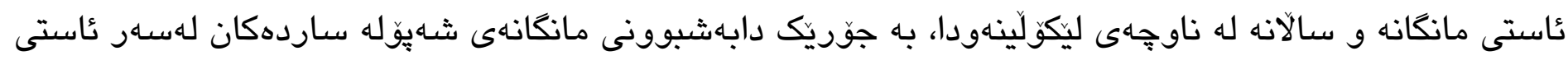

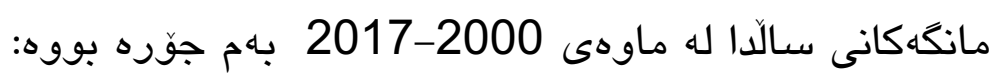

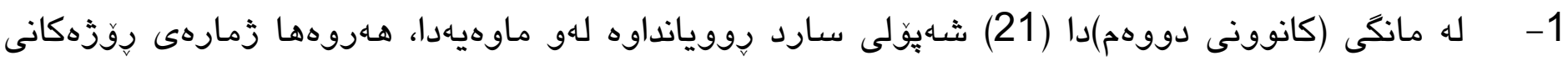

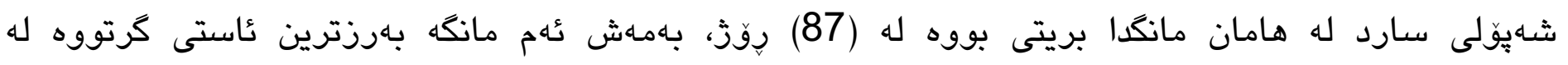

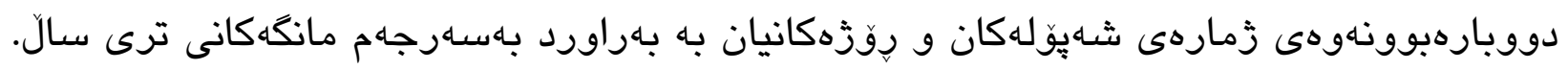

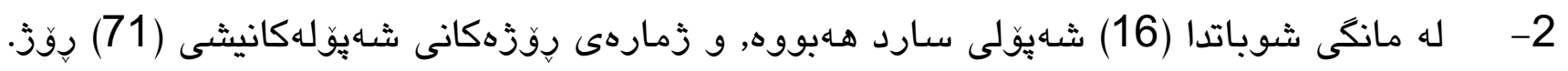




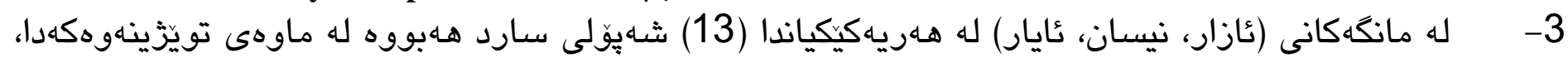

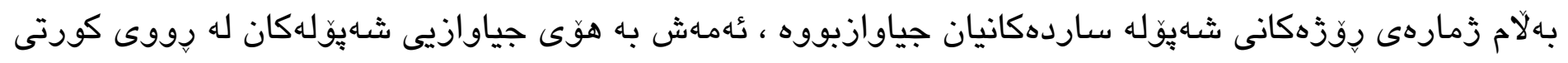

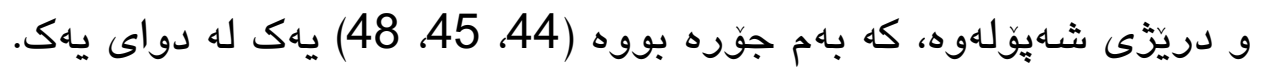

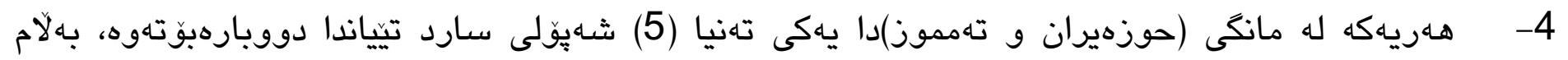

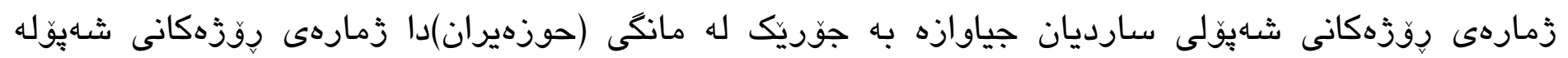

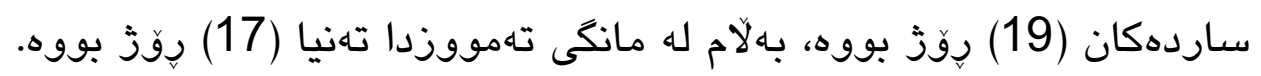

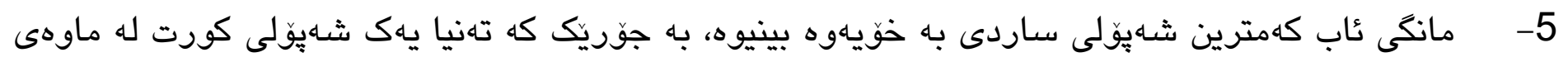

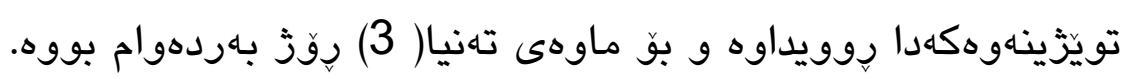

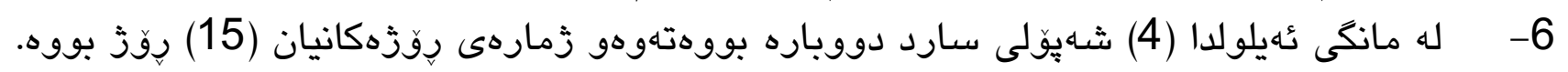


Journal of University of Raparin $\quad$ كوّقارى زانكوّى رابهرين

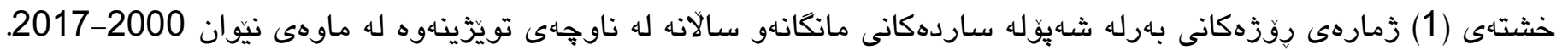

\begin{tabular}{|c|c|c|c|c|c|c|c|c|c|c|c|c|c|c|}
\hline ن اوهند & سهرجهم & كانونى يهكهم & دووهرينى & تشكرينى & ئهيلول & كاب & تهمووز & حوزهيران & ل & نيسان & ئادار & شوبات & كانونى & سال سال \\
\hline 3.92 & 47 & 4 & 1 & 13 & 1 & 4 & 3 & 1 & 4 & 2 & 5 & 4 & 5 & 2000 \\
\hline 3.75 & 45 & 5 & 9 & 9 & 1 & 1 & 5 & 1 & 3 & 1 & & 6 & 4 & 2001 \\
\hline 5.5 & 66 & 10 & 2 & 7 & & & 1 & 5 & 4 & 4 & 8 & 17 & 8 & 2002 \\
\hline 4 & 48 & 2 & 10 & 4 & 7 & 1 & & 6 & 7 & 3 & 3 & 2 & 3 & 2003 \\
\hline 5.08 & 61 & 2 & 7 & 4 & 4 & 5 & 2 & 4 & 8 & 8 & 6 & 6 & 5 & 2004 \\
\hline 4.58 & 55 & 6 & 1 & 11 & 2 & 1 & 2 & 1 & 6 & 5 & 7 & 8 & 5 & 2005 \\
\hline 3.75 & 45 & 3 & 4 & 5 & 4 & 3 & 1 & & 5 & 6 & 5 & 4 & 5 & 2006 \\
\hline 4.42 & 53 & 6 & 5 & 3 & 3 & & 2 & 2 & 6 & 5 & 3 & 6 & 12 & 2007 \\
\hline 5.17 & 62 & 4 & & 7 & 5 & & 4 & 2 & 4 & 9 & 9 & 8 & 10 & 2008 \\
\hline 3.17 & 38 & 2 & 6 & 3 & 3 & & & 2 & 5 & 3 & 6 & 1 & 7 & 2009 \\
\hline 3.08 & 37 & 3 & & 5 & & & 4 & 2 & 6 & 2 & 7 & 4 & 4 & 2010 \\
\hline 4.08 & 49 & 1 & 7 & 7 & 2 & & 3 & 1 & 6 & 4 & 3 & 8 & 7 & 2011 \\
\hline 3.42 & 41 & & 3 & 4 & 3 & 1 & 5 & 4 & 2 & 3 & 8 & 4 & 4 & 2012 \\
\hline 3.92 & 47 & 11 & & 5 & 2 & & & 2 & 5 & 5 & 5 & 2 & 10 & 2013 \\
\hline 5.58 & 67 & & 3 & 8 & 2 & 3 & 3 & 4 & 4 & 7 & 12 & 12 & 9 & 2014 \\
\hline 3.5 & 42 & 3 & 1 & 6 & 3 & 3 & 1 & & 8 & 6 & 3 & 3 & 5 & 2015 \\
\hline 4.42 & 53 & 4 & 8 & 5 & 4 & & 3 & 4 & 5 & 6 & 3 & 4 & 7 & 2016 \\
\hline \multirow[t]{3}{*}{4} & 48 & 8 & 7 & 6 & 2 & & 2 & 3 & 6 & 6 & 1 & 5 & 2 & 2017 \\
\hline & 904 & 74 & 74 & 112 & 48 & 22 & 41 & 44 & 94 & 85 & 94 & 104 & 112 & كوى كثتى \\
\hline & 50.2 & 4.1 & 4.1 & 6.2 & 2.7 & 1.2 & 2.3 & 2.4 & 5.2 & 4.7 & 5.2 & 5.8 & 6.2 & ناوهند (تيكرا) \\
\hline
\end{tabular}

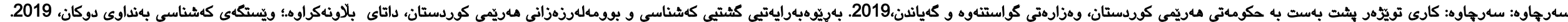

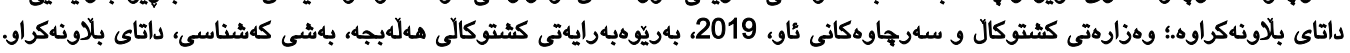

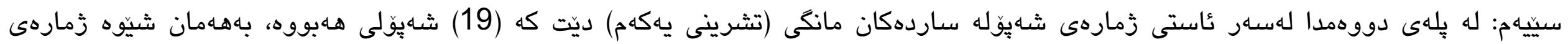

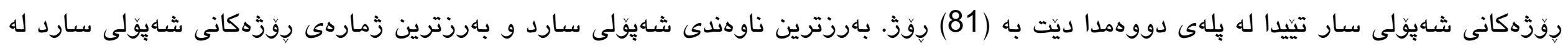

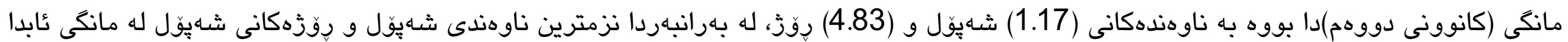

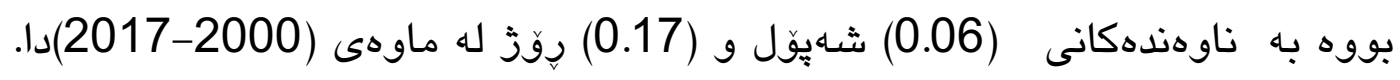

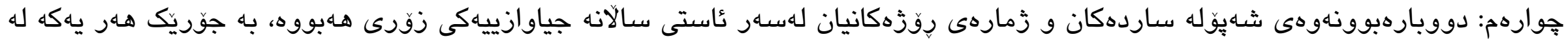

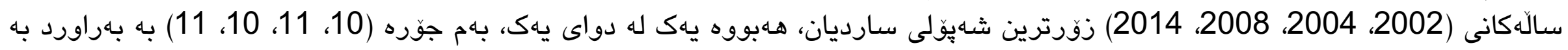
سارجهم سالّكانى ترى ماوهى تويَّزينهوهكهدا 


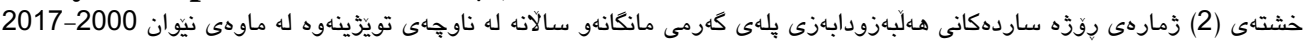

\begin{tabular}{|c|c|c|c|c|c|c|c|c|c|c|c|c|c|c|}
\hline ناوهند & سهرجهم & كانونى & تشروينى & تشهرينى & ئهيلول & ئاب & تهمووز & حوزديران & ئايار & نيسان & 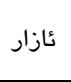 & شوبات & كانونى & سال سال \\
\hline 1.5 & 18 & & 1 & 3 & 1 & 1 & & 1 & 4 & 2 & 2 & 1 & 2 & 2000 \\
\hline 1.58 & 19 & 2 & 2 & & 1 & 1 & 5 & 1 & 3 & 1 & & 2 & 1 & 2001 \\
\hline 2 & 24 & 2 & 2 & 4 & & & 1 & 2 & 4 & 1 & 5 & 2 & 1 & 2002 \\
\hline 0.92 & 11 & 2 & & 1 & 1 & 1 & & & 1 & 3 & & 2 & & 2003 \\
\hline 2.08 & 25 & 2 & & 1 & 1 & 5 & 2 & 1 & 5 & 4 & 2 & & 2 & 2004 \\
\hline 1.08 & 13 & & 1 & & 2 & 1 & 2 & 1 & 1 & 1 & 4 & & & 2005 \\
\hline 2.25 & 27 & & 4 & 2 & 4 & 3 & 1 & & 2 & 6 & 2 & 1 & 2 & 2006 \\
\hline 2.5 & 30 & 1 & 1 & 3 & 3 & & 2 & 2 & 3 & 5 & 3 & 3 & 4 & 2007 \\
\hline 1.5 & 18 & 4 & & & 2 & & 1 & 2 & 4 & 1 & 1 & 2 & 1 & 2008 \\
\hline 1.58 & 19 & 2 & 3 & 3 & & & & 2 & 2 & 3 & 3 & 1 & & 2009 \\
\hline 1.42 & 17 & 3 & & 2 & & & 1 & 2 & & 2 & 7 & & & 2010 \\
\hline 1.42 & 17 & 1 & 2 & 1 & 2 & & 3 & 1 & 2 & & 3 & 2 & & 2011 \\
\hline 1.25 & 15 & & & & 3 & 1 & & & 2 & & 4 & 4 & 1 & 2012 \\
\hline 2.08 & 25 & 5 & & 5 & 2 & & & 2 & 5 & 2 & 2 & 2 & & 2013 \\
\hline 2.25 & 27 & & 3 & 1 & 2 & 3 & & 4 & 1 & & 5 & 2 & 6 & 2014 \\
\hline 2.33 & 28 & 3 & 1 & 2 & 3 & 3 & 1 & & 5 & 3 & 3 & 3 & 1 & 2015 \\
\hline 2.25 & 27 & 1 & & 2 & 4 & & 3 & 4 & 1 & 3 & 3 & 4 & 2 & 2016 \\
\hline \multirow[t]{3}{*}{1.17} & 14 & & & 1 & 2 & & 2 & & 1 & 3 & 1 & 2 & 2 & 2017 \\
\hline & 374 & 28 & 20 & 31 & 33 & 19 & 24 & 25 & 46 & 40 & 50 & 33 & 25 & كوى كشتى \\
\hline & 20.8 & 1.6 & 1.1 & 1.7 & 1.8 & 1.05 & 1.3 & 1.4 & 2.6 & 2.2 & 2.8 & 1.8 & 1.4 & ناوهند (تيكرا) \\
\hline
\end{tabular}

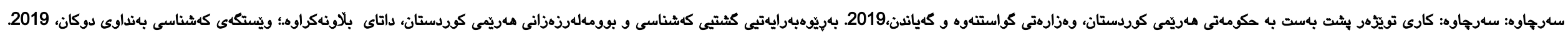

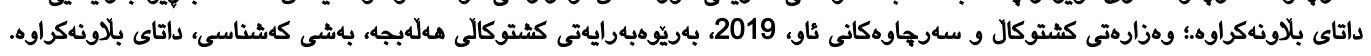

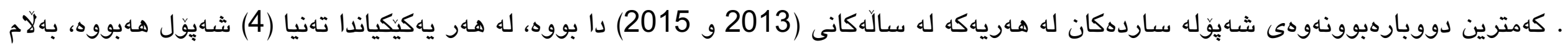

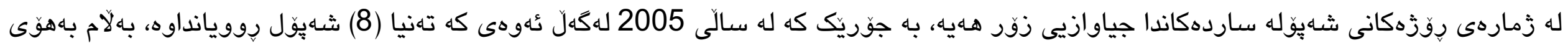

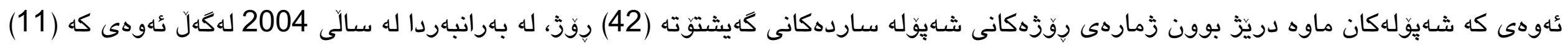

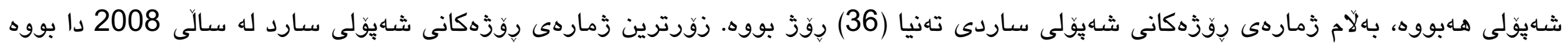

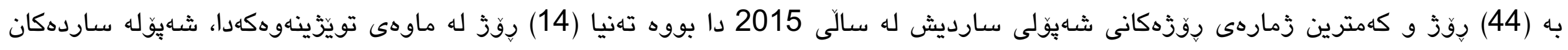

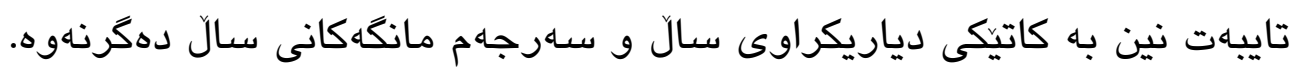


Journal of University of Raparin $\quad$ كؤقارى زانكوّى رإِهرين

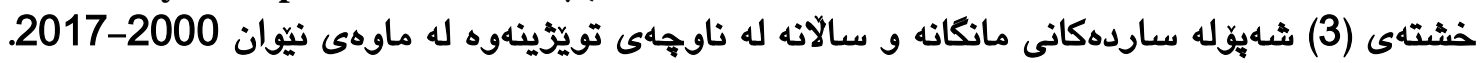

\begin{tabular}{|c|c|c|c|c|c|c|c|c|c|c|c|c|c|c|}
\hline ناوهند & سهرجهم & كانونى & تشروينى & تشرينى & كُهيلول & عاب & تهمووز & حوزهيران & كايار & نيسان & تئازار & شوبات & كانونى & سال \\
\hline 0.67 & 8 & 1 & & 2 & & 1 & 1 & & & & 1 & 1 & 1 & 2000 \\
\hline 0.5 & 6 & 1 & 1 & 2 & & & & & & & & 1 & 1 & 2001 \\
\hline 0.83 & 10 & 2 & & 1 & & & & 1 & & 1 & 1 & 2 & 2 & 2002 \\
\hline 0.75 & 9 & & 2 & 1 & 1 & & & 1 & 2 & & 1 & & 1 & 2003 \\
\hline 0.92 & 11 & & 2 & 1 & 1 & & & 1 & 1 & 1 & 1 & 2 & 1 & 2004 \\
\hline 0.67 & 8 & 1 & & 2 & & & & & 1 & 1 & 1 & 1 & 1 & 2005 \\
\hline 0.5 & 6 & 1 & & 1 & & & & & 1 & & 1 & 1 & 1 & 2006 \\
\hline 0.5 & 6 & 1 & 1 & & & & & & 1 & & & 1 & 2 & 2007 \\
\hline 0.83 & 10 & & & 1 & 1 & & 1 & & & 2 & 2 & 1 & 2 & 2008 \\
\hline 0.5 & 6 & & 1 & & 1 & & & & 1 & & 1 & & 2 & 2009 \\
\hline 0.42 & 5 & & & 1 & & & 1 & & 1 & & & 1 & 1 & 2010 \\
\hline 0.58 & 7 & & 1 & 2 & & & & & 1 & 1 & & 1 & 1 & 2011 \\
\hline 0.58 & 7 & & 1 & 1 & & & 1 & 1 & & 1 & 1 & & 1 & 2012 \\
\hline 0.33 & 4 & 1 & & & & & & & & 1 & 1 & & 1 & 2013 \\
\hline 0.92 & 11 & & & 1 & & & 1 & & 1 & 2 & 2 & 3 & 1 & 2014 \\
\hline 0.33 & 4 & & & 1 & & & & & 1 & 1 & & & 1 & 2015 \\
\hline 0.5 & 6 & 1 & 1 & 1 & & & & & 1 & 1 & & & 1 & 2016 \\
\hline \multirow[t]{3}{*}{0.67} & 8 & 2 & 1 & 1 & & & & 1 & 1 & 1 & & 1 & & 2017 \\
\hline & 132 & 11 & 11 & 19 & 4 & 1 & 5 & 5 & 13 & 13 & 13 & 16 & 21 & كوى كثتى \\
\hline & 7.33 & 0.61 & 0.61 & 1.06 & 0.22 & 0.06 & 0.28 & 0.28 & 0.72 & 0.72 & 0.72 & 0.89 & 1.17 & ناوهند(تيكرا) \\
\hline
\end{tabular}

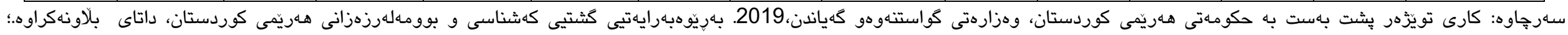

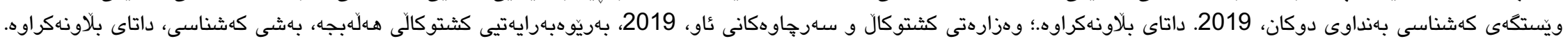


Journal of University of Raparin $\quad$ كوَقارى زانكوّى رابهرين

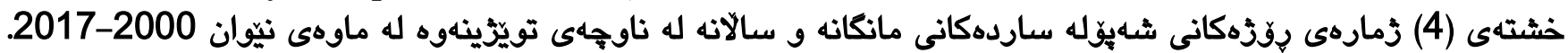

\begin{tabular}{|c|c|c|c|c|c|c|c|c|c|c|c|c|c|c|}
\hline ناوهند & سـارجهام & كانونى & دووهرينى & تشنرينى & تُهيلول & عاب & تهمووز & حوزهيران & تايار & نيسان & تئازار & شوبات & كانونى & سـال \\
\hline 2.42 & 29 & 4 & & 10 & & 3 & 3 & & & & 3 & 3 & 3 & 2000 \\
\hline 2.17 & 26 & 3 & 7 & 9 & & & & & & & & 4 & 3 & 2001 \\
\hline 3.5 & 42 & 8 & & 3 & & & & 3 & & 3 & 3 & 15 & 7 & 2002 \\
\hline 3.08 & 37 & & 10 & 3 & 6 & & & 6 & 6 & & 3 & & 3 & 2003 \\
\hline 3 & 36 & & 7 & 3 & 3 & & & 3 & 3 & 4 & 4 & 6 & 3 & 2004 \\
\hline 3.5 & 42 & 6 & & 11 & & & & & 5 & 4 & 3 & 8 & 5 & 2005 \\
\hline 1.5 & 18 & 3 & & 3 & & & & & 3 & & 3 & 3 & 3 & 2006 \\
\hline 1.92 & 23 & 5 & 4 & & & & & & 3 & & & 3 & 8 & 2007 \\
\hline 3.67 & 44 & & & 7 & 3 & & 3 & & & 8 & 8 & 6 & 9 & 2008 \\
\hline 1.58 & 19 & & 3 & & 3 & & & & 3 & & 3 & & 7 & 2009 \\
\hline 1.67 & 20 & & & 3 & & & 3 & & 6 & & & 4 & 4 & 2010 \\
\hline 2.67 & 32 & & 5 & 6 & & & & & 4 & 4 & & 6 & 7 & 2011 \\
\hline 2.17 & 26 & & 3 & 4 & & & 5 & 4 & & 3 & 4 & & 3 & 2012 \\
\hline 1.83 & 22 & 6 & & & & & & & & 3 & 3 & & 10 & 2013 \\
\hline 3.33 & 40 & & & 7 & & & 3 & & 3 & 7 & 7 & 10 & 3 & 2014 \\
\hline 1.17 & 14 & & & 4 & & & & & 3 & 3 & & & 4 & 2015 \\
\hline 2.17 & 26 & 3 & 8 & 3 & & & & & 4 & 3 & & & 5 & 2016 \\
\hline 2.83 & 34 & 8 & 7 & 5 & & & & 3 & 5 & 3 & & 3 & & 2017 \\
\hline & 530 & 46 & 54 & 81 & 15 & 3 & 17 & 19 & 48 & 45 & 44 & 71 & 87 & كوى كُشتى \\
\hline & 29.44 & 2.56 & 3 & 4.5 & 0.83 & 0.17 & 0.94 & 1.06 & 2.67 & 2.5 & 2.44 & 3.94 & 4.83 & ناوهند (تيكِيا) \\
\hline
\end{tabular}

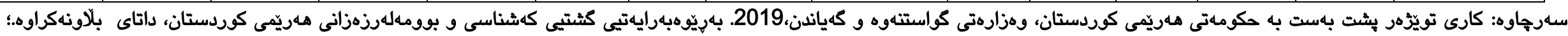

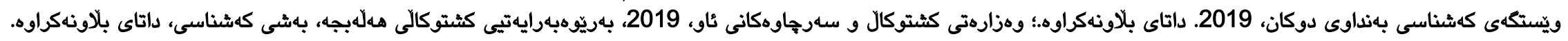

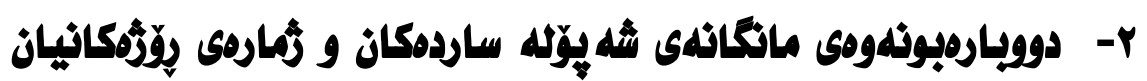

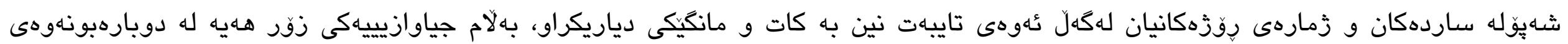

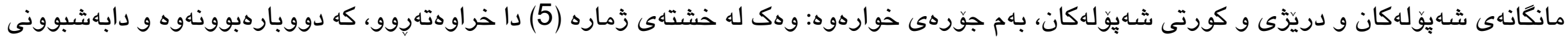

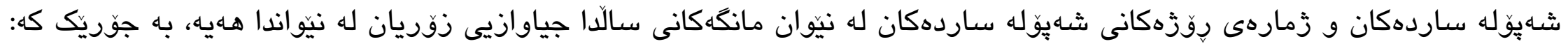

DOI:https://doi.org/10.26750/Vol(8).No(2).Paper_14 http://journal.uor.edu.krd/index.php/JUR Vol.8. No.2,June.2021 

2017

\begin{tabular}{|c|c|c|c|c|c|}
\hline \multicolumn{2}{|c|}{ 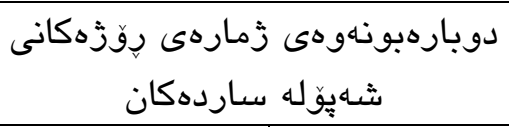 } & \multicolumn{2}{|c|}{ دووبارهبوونهودى شـاهيوله } & \multirow[b]{2}{*}{ مانكَكان } & \multirow[b]{2}{*}{$\dot{j}$} \\
\hline 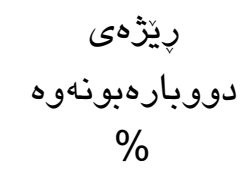 & دووبارهبونهوه & دووبارهبونهوه رِيزّى & دووبارهبونهوه & & \\
\hline 16.41 & 87 & 15.91 & 21 & كانونى دووهم & 1 \\
\hline 13.4 & 71 & 12.12 & 16 & شوبات & 2 \\
\hline 8.3 & 44 & 9.85 & 13 & عازار & 3 \\
\hline 8.49 & 45 & 9.85 & 13 & نيسان & 4 \\
\hline 9.06 & 48 & 9.85 & 13 & ئايار & 5 \\
\hline 3.58 & 19 & 3.79 & 5 & حوزهيران & 6 \\
\hline 3.21 & 17 & 3.79 & 5 & تهمووز & 7 \\
\hline 0.57 & 3 & 0.75 & 1 & ئاب & 8 \\
\hline 2.83 & 15 & 3.03 & 4 & ئهيلول & 9 \\
\hline 15.28 & 81 & 14.4 & 19 & تشرينى يهكهم & 10 \\
\hline 10.19 & 54 & 8.33 & 11 & تشرينى دووهم & 11 \\
\hline 8.68 & 46 & 8.33 & 11 & كانونى يـكهم & 12 \\
\hline 100 & 530 & 100 & 132 & سـهرجهم & \\
\hline
\end{tabular}

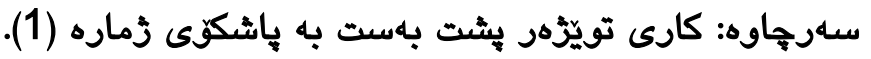

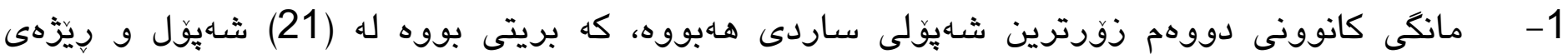

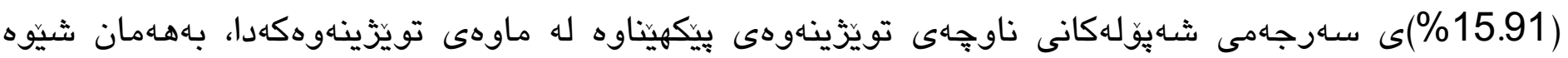

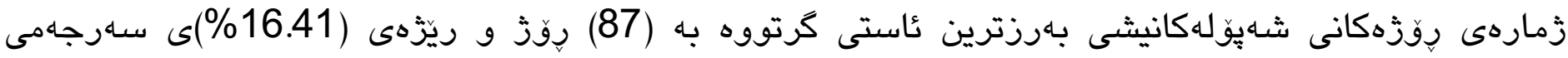

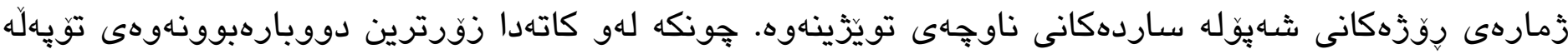

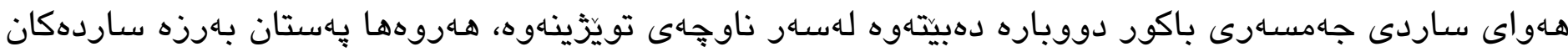

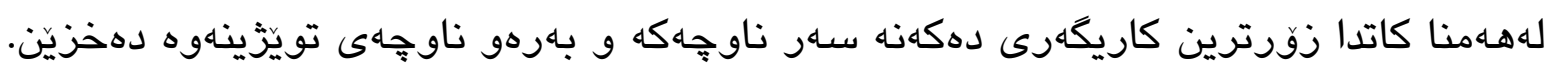

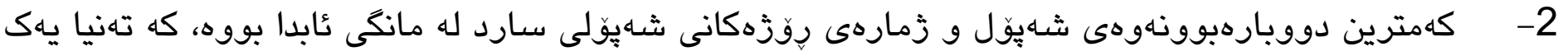

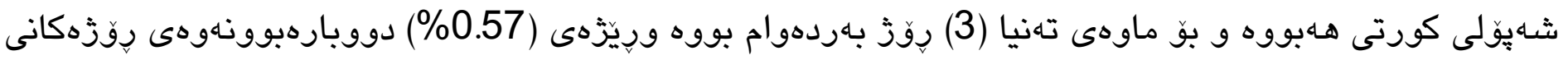

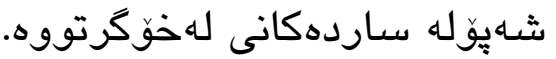

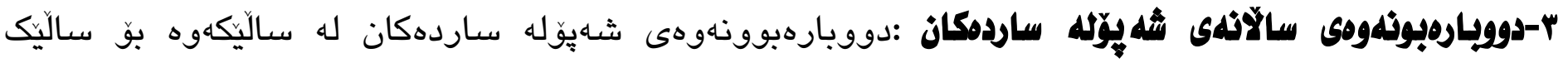

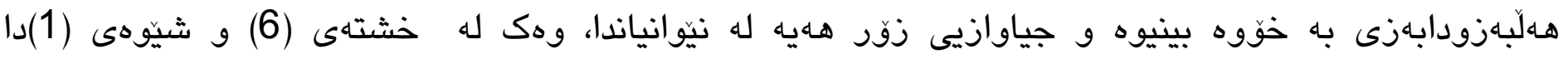

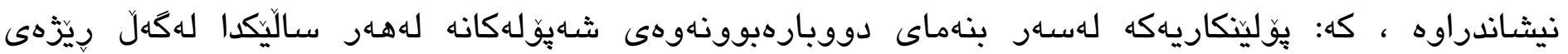

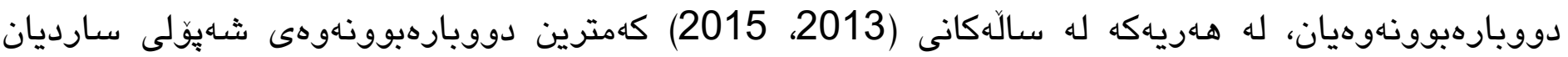

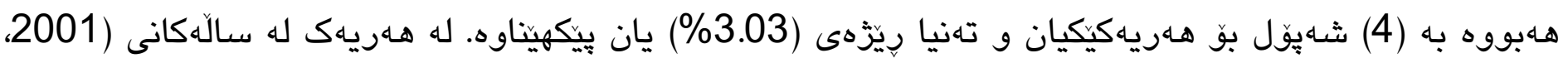




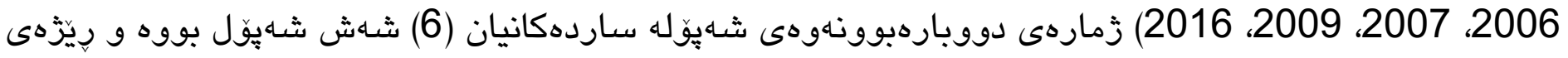

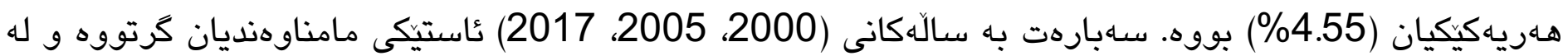

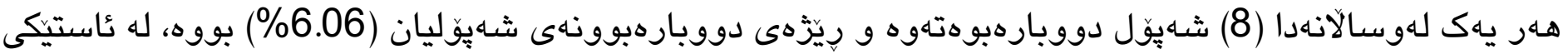

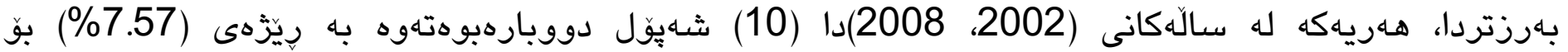

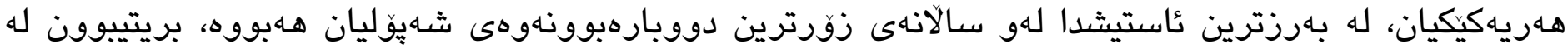

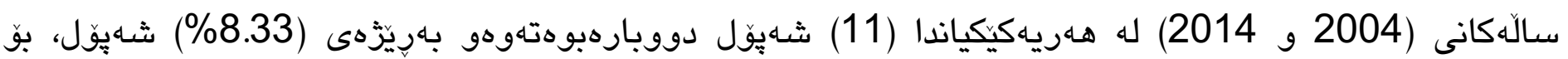

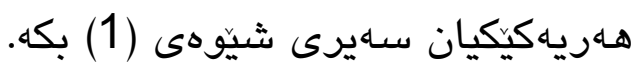

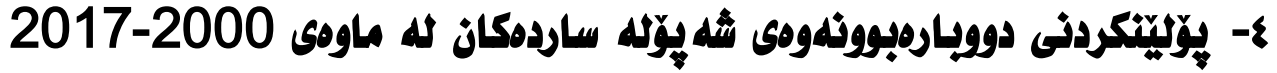

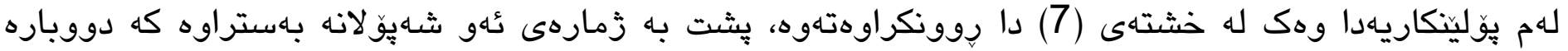

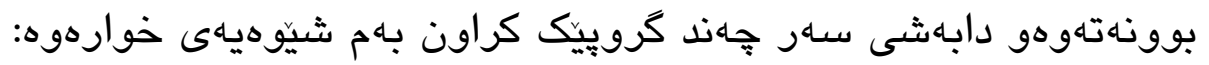

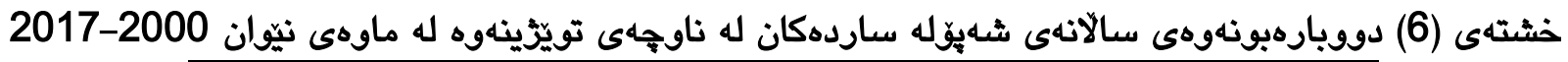

\begin{tabular}{|c|c|c|c|}
\hline رِيَّهى دوويارهبونهوه & 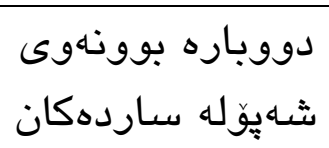 & سال & $\dot{j}$ \\
\hline 6.06 & 8 & 2000 & 1 \\
\hline 4.55 & 6 & 2001 & 2 \\
\hline 7.57 & 10 & 2002 & 3 \\
\hline 6.82 & 9 & 2003 & 4 \\
\hline 8.33 & 11 & 2004 & 5 \\
\hline 6.06 & 8 & 2005 & 6 \\
\hline 4.55 & 6 & 2006 & 7 \\
\hline 4.55 & 6 & 2007 & 8 \\
\hline 7.57 & 10 & 2008 & 9 \\
\hline 4.55 & 6 & 2009 & 10 \\
\hline 3.79 & 5 & 2010 & 11 \\
\hline 5.3 & 7 & 2011 & 12 \\
\hline 5.3 & 7 & 2012 & 13 \\
\hline 3.03 & 4 & 2013 & 14 \\
\hline 8.33 & 11 & 2014 & 15 \\
\hline 3.03 & 4 & 2015 & 16 \\
\hline 4.55 & 6 & 2016 & 17 \\
\hline 6.06 & 8 & 2017 & 18 \\
\hline 100 & 132 & \multicolumn{2}{|c|}{ كوّى كُشتى } \\
\hline
\end{tabular}

سهرجاوه: كارى تويّزهر بشت بهست به باشكوى زماره (1). 


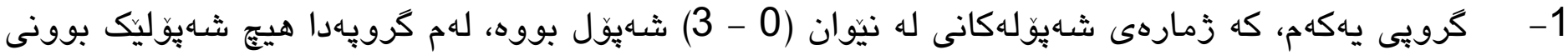

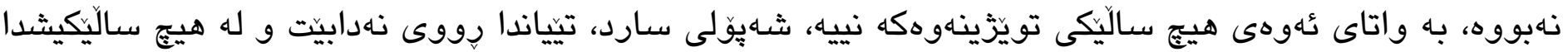

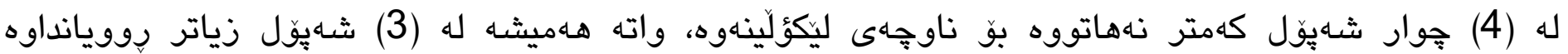

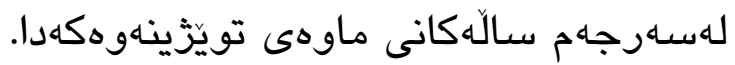

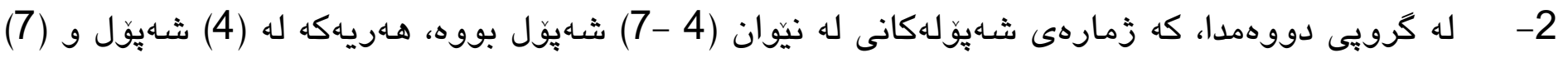

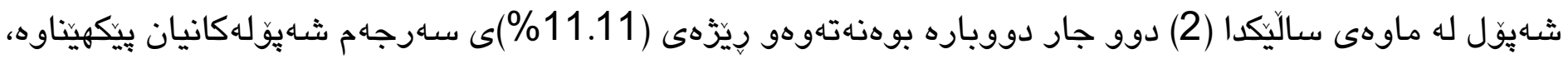

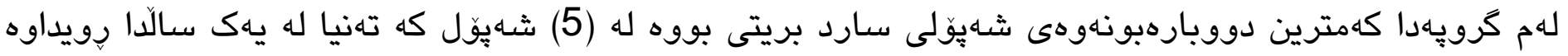

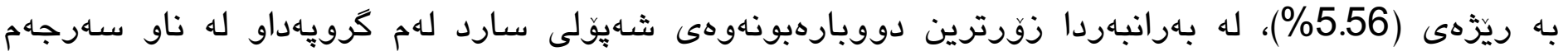

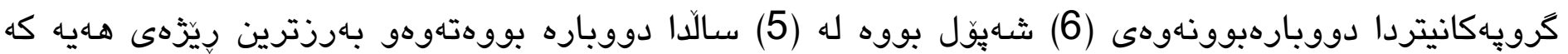

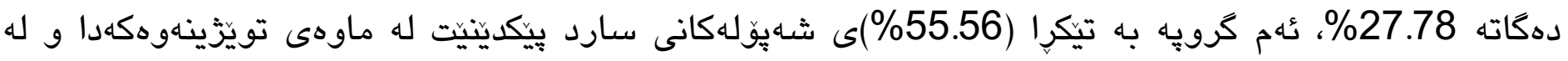

ناوجهاءى تويزّينهوهكهماندا.

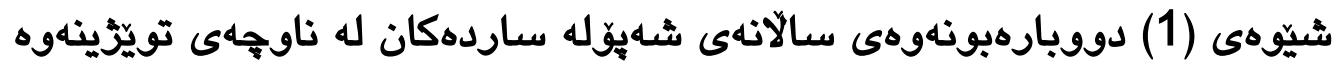
له ماوهى نيّان (2000-2017)

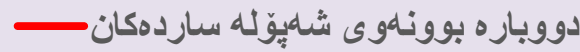

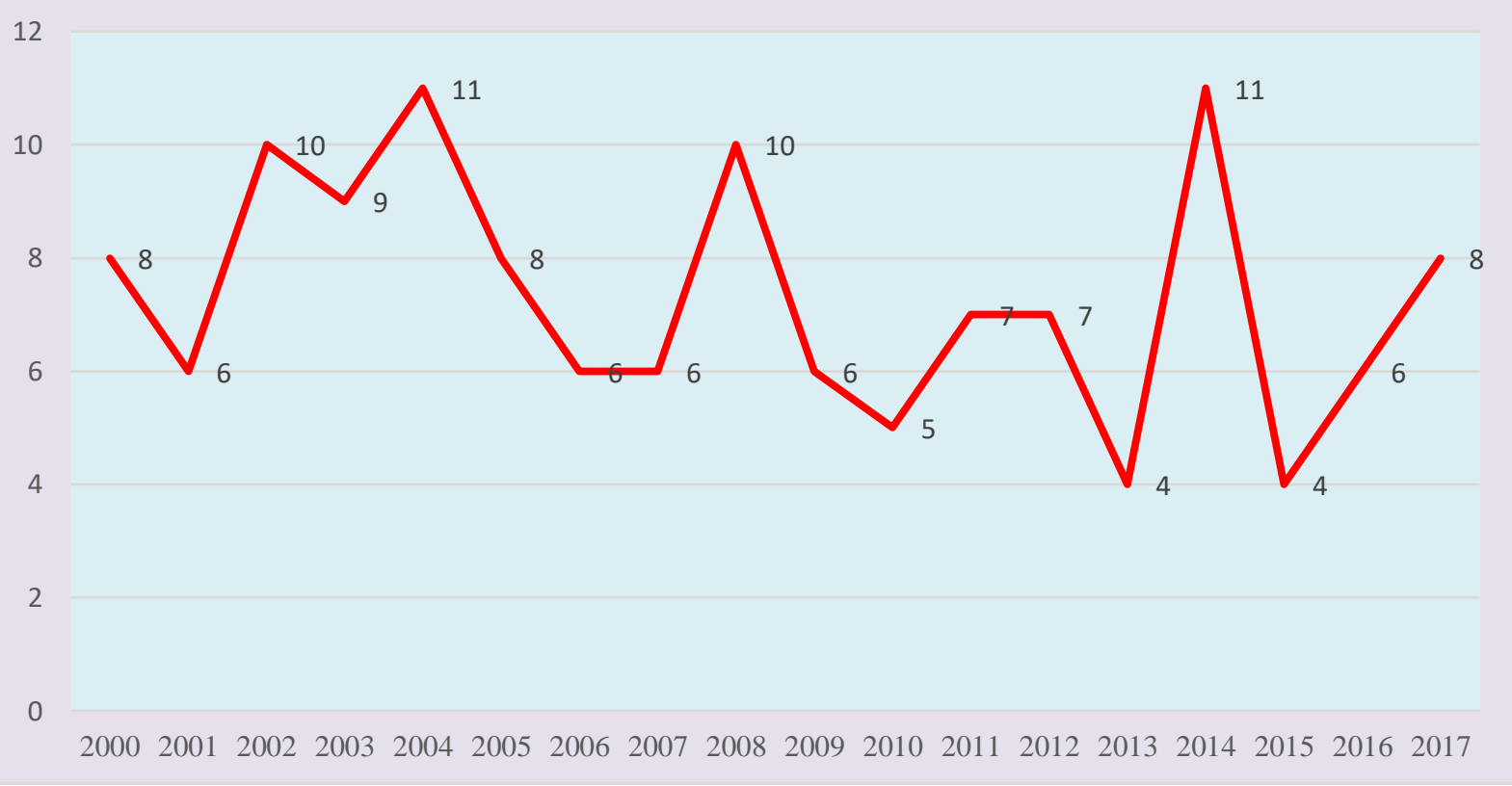

سهرجاوه: كارى تويَّهر، بشتبهست به خشتهى (6).

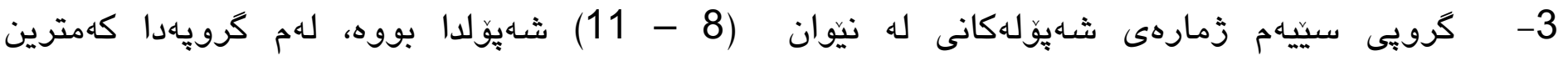

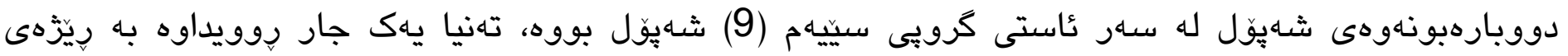

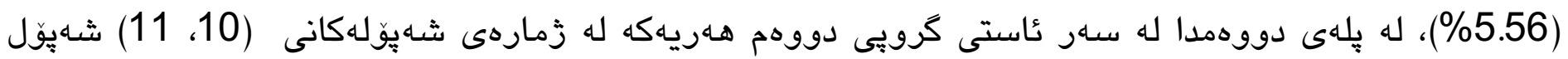

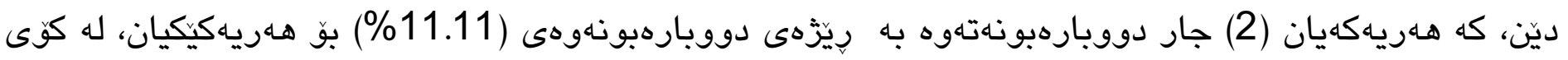

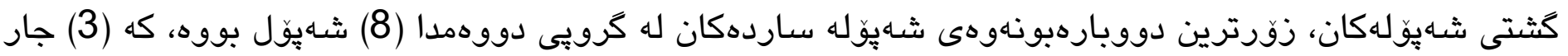




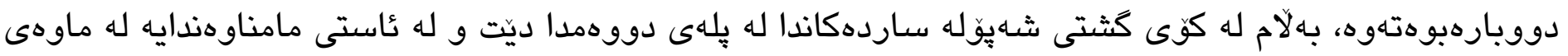

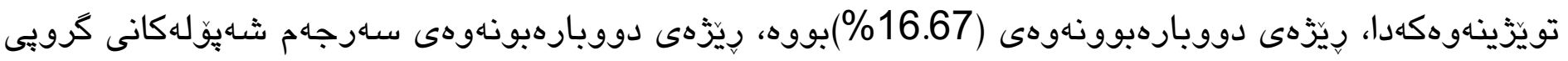

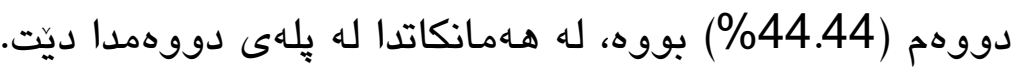

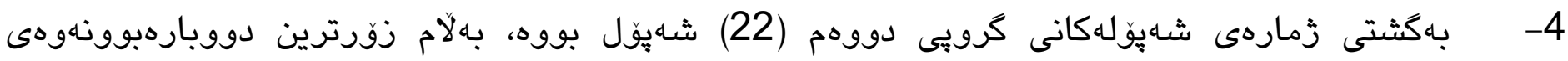

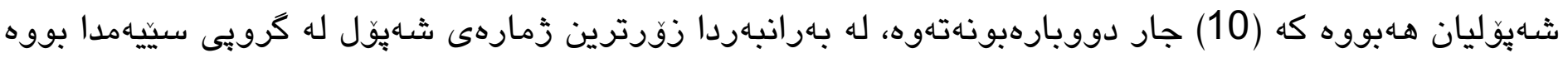

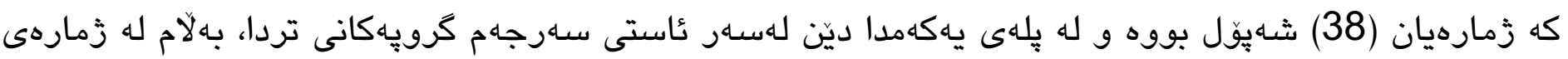

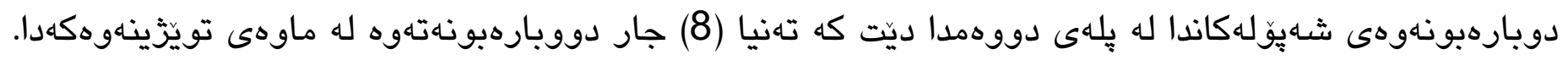

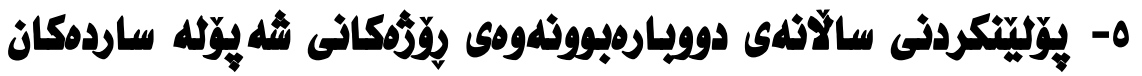

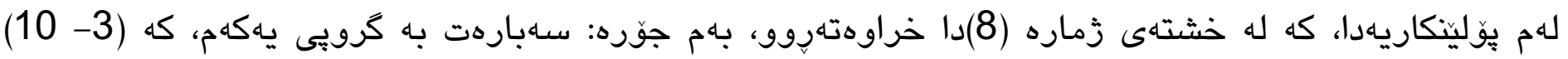

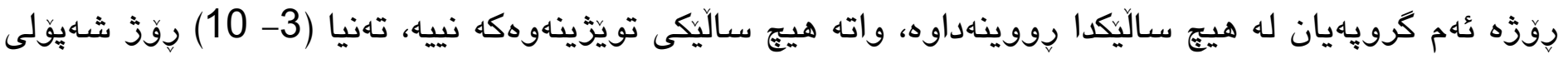

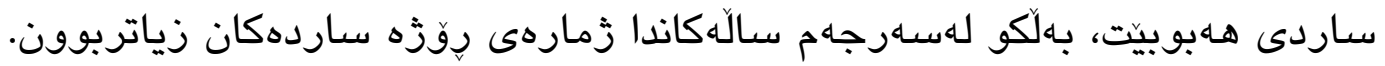

خشتهى (7) يوّلينكردنى دووبارهبونهوهى شهايوله ساردهكان له ناوجهى تويّزينهوه له ماوهى نيّوان (2000-

(2017

\begin{tabular}{|c|c|c|c|c|c|}
\hline$\%$ & دووبارهبونهوهيان ريّزهى \% & دوويارهبوونهوهيان & زَمارهى شـاهِّلهكان & j & كرويهكان \\
\hline \multirow{4}{*}{0} & 0 & 0 & 0 & 1 & \multirow{4}{*}{ يُ كرويى } \\
\hline & 0 & 0 & 1 & 2 & \\
\hline & 0 & 0 & 2 & 3 & \\
\hline & 0 & 0 & 3 & 4 & \\
\hline \multirow{4}{*}{$\% 55.56$} & $\% 11.11$ & 2 & 4 & 5 & \multirow{4}{*}{ دورويى } \\
\hline & $\% 5.56$ & 1 & 5 & 6 & \\
\hline & $\% 27.78$ & 5 & 6 & 7 & \\
\hline & $\% 11.11$ & 2 & 7 & 8 & \\
\hline \multirow{4}{*}{$\% 44.44$} & $\% 16.66$ & 3 & 8 & 9 & \multirow{4}{*}{ كرويى سيّيه م } \\
\hline & $\% 5.56$ & 1 & 9 & 10 & \\
\hline & $\% 11.11$ & 2 & 10 & 11 & \\
\hline & $\% 11.11$ & 2 & 11 & 12 & \\
\hline \multicolumn{2}{|r|}{100} & 18 & \multicolumn{3}{|c|}{ كوى كَثتى } \\
\hline
\end{tabular}

سهرجاوه: كارى تويّزّهر، يشت بهست به هاشكوى زماره (1) (1).

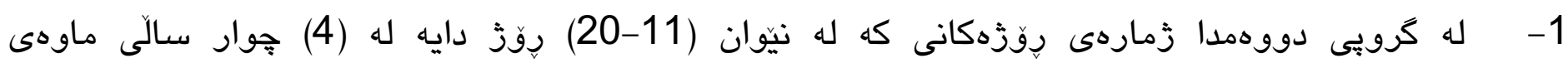
تويّزينهوه

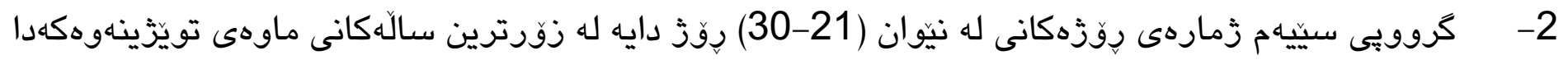

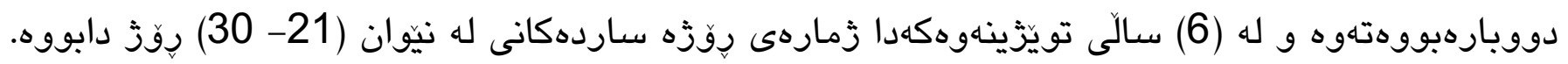


Journal of University of Raparin

كوّقارى زانكوّى رابِّرين

E-ISSN: 2522 - 7130 P-ISSN: 2410 - 1036

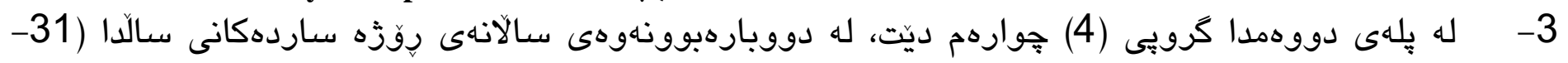

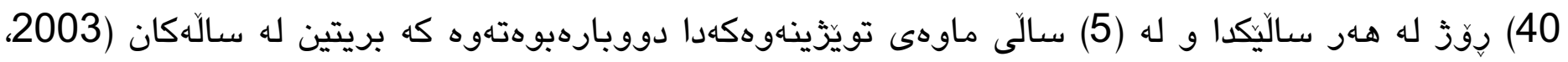

2004، 2017، 2011، 2014،

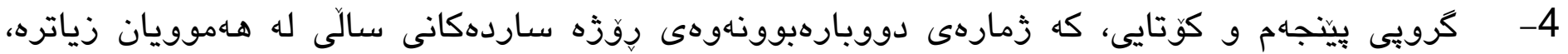

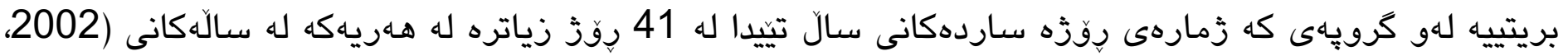

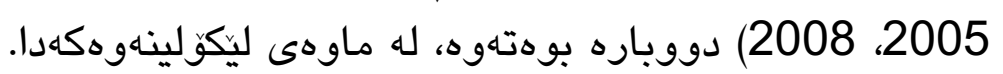

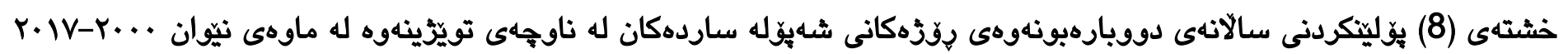

\begin{tabular}{|c|c|c|c|c|}
\hline زمارهى سالَكان & سالةكان & دووبارهبونهوه (سال) & 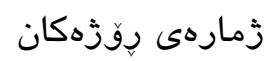 & كروبه كان \\
\hline 0 & 0 & 0 & 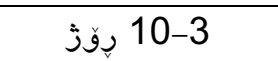 & 1 \\
\hline 4 & $2015,2010,2009,2006$ & 4 & 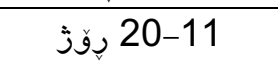 & 2 \\
\hline 6 & $\begin{array}{c}2016,2013,2012,2007,2001, \\
2000\end{array}$ & 6 & 30-21 بِقذ & 3 \\
\hline 5 & $2017,2014,2011,2004,2003$ & 5 & ل -31-40 رقذ & 4 \\
\hline 3 & $2008,2005,2002$ & 3 & l 41 بوقذ و زياتر & 5 \\
\hline 18 & $2017-2000$ & 18 & \multicolumn{2}{|l|}{ 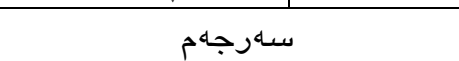 } \\
\hline
\end{tabular}

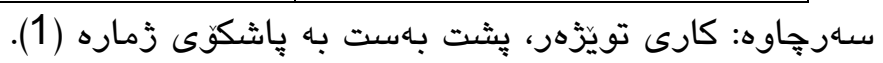

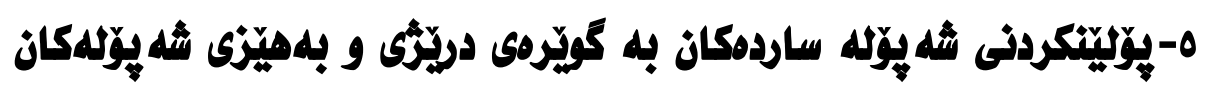

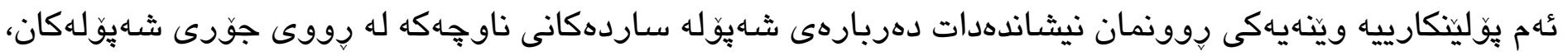

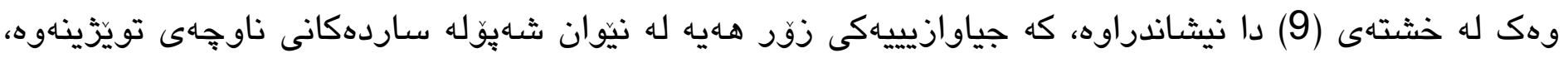

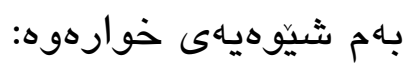

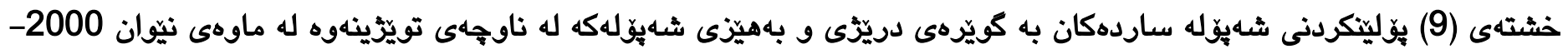
2017

\begin{tabular}{|c|c|c|c|c|}
\hline 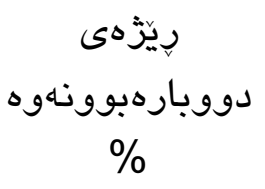 & دووبارهبوونهوهيان & جوّرى شـهيول & زે & بِّولِينَهكان \\
\hline 84.85 & 112 & شهيوله كورتهكان & 1 & \multirow{3}{*}{ يَّْ لَيْنكارى } \\
\hline 13.64 & 18 & شـهِوله مامناوهندهان & 2 & \\
\hline 1.51 & 2 & شـهيَله دريَزْكان & 3 & \\
\hline 100 & 132 & \multicolumn{3}{|l|}{ سهارجهم } \\
\hline 67.42 & 89 & شـهِّله مامناوهنده ساردهكان & 1 & \multirow{3}{*}{ يَّْ لِينكارى } \\
\hline 22.73 & 30 & شنهيّله بههيزّكان & 2 & \\
\hline 9.85 & 13 & شـهِّله زوَر بههيَزهكان & 3 & \\
\hline 100 & 132 & \multicolumn{3}{|l|}{ سهرجهم } \\
\hline 59.85 & 79 & شـهِّله كورت ومامناوهندهكان & 1 & \\
\hline
\end{tabular}

330

DOI:https://doi.org/10.26750/Vol(8).No(2).Paper_14 http://journal.uor.edu.krd/index.php/JUR Vol.8. No.2,June.2021 


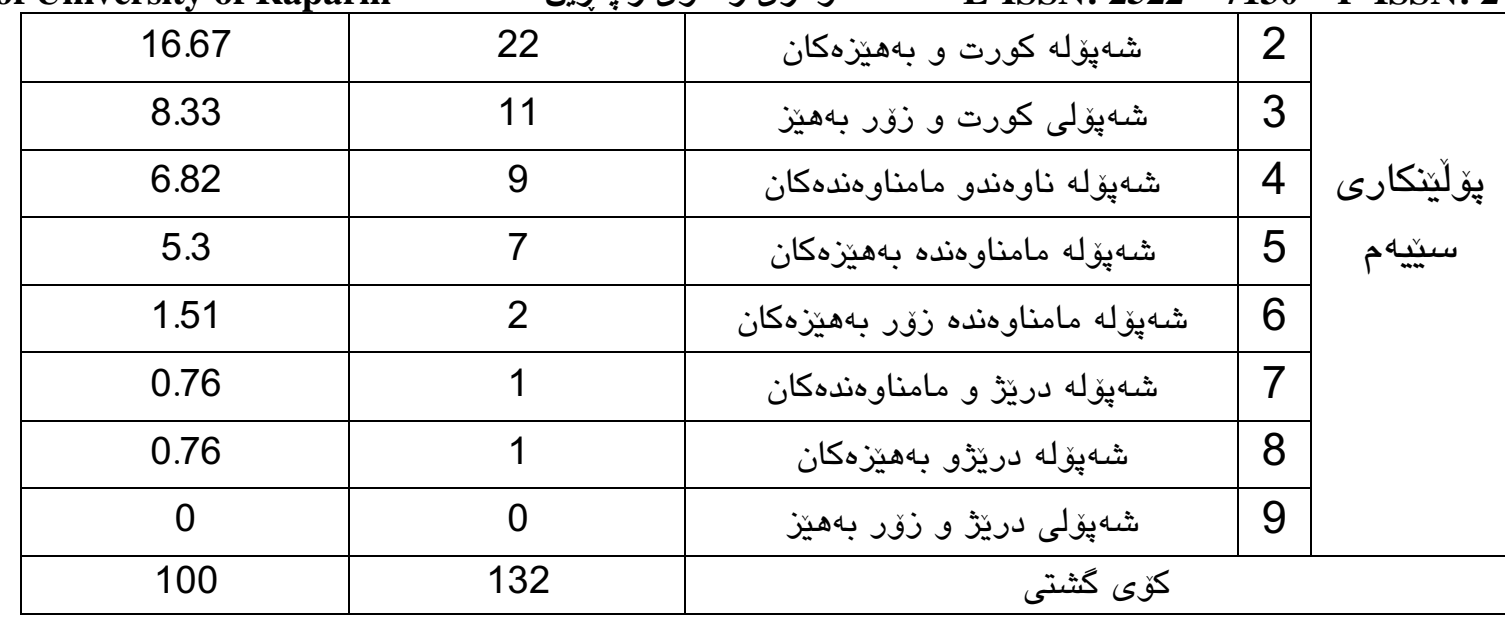

سهرجاوه: كارى تويّزّهر، بشت بهست به هاشكوى زماره (1).

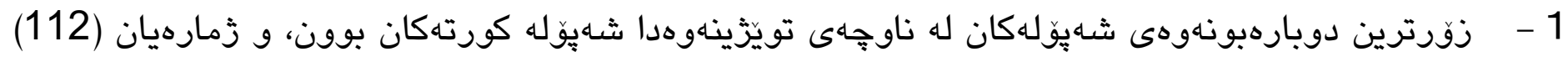

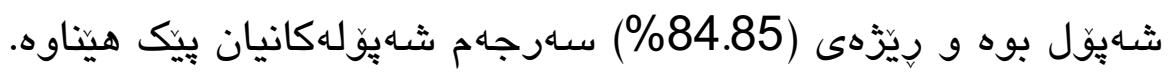

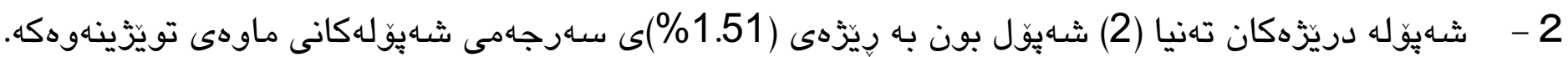

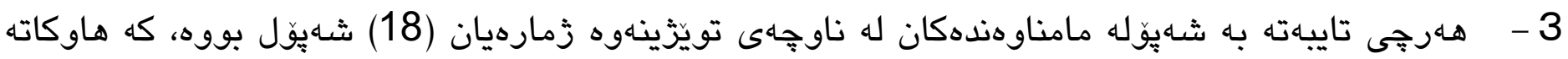

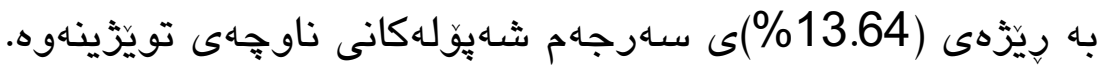

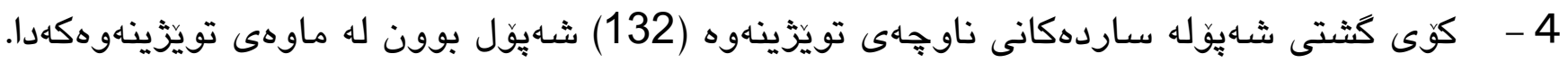

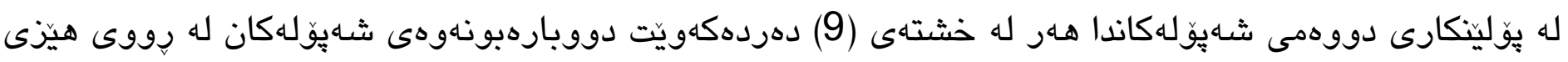

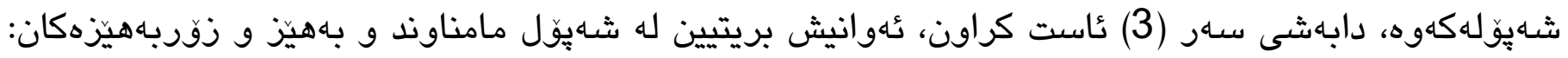

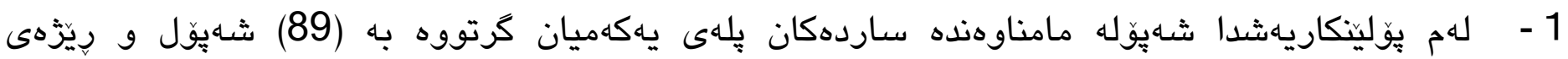

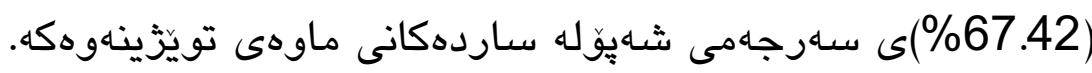
2 - 2

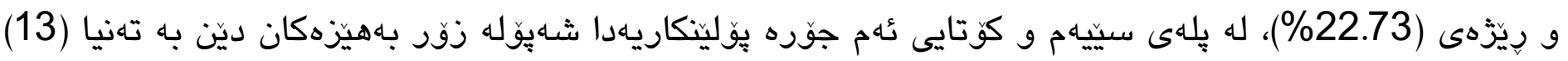

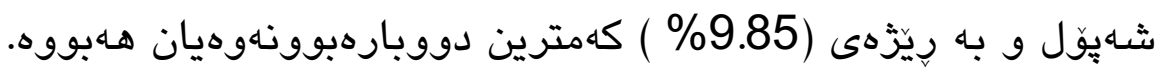

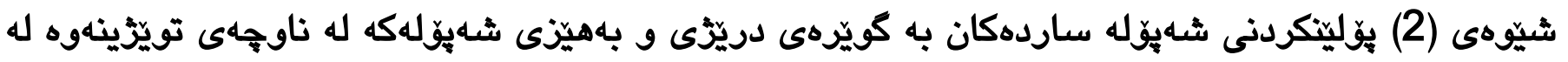

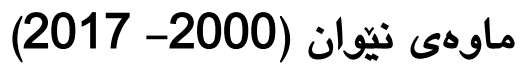




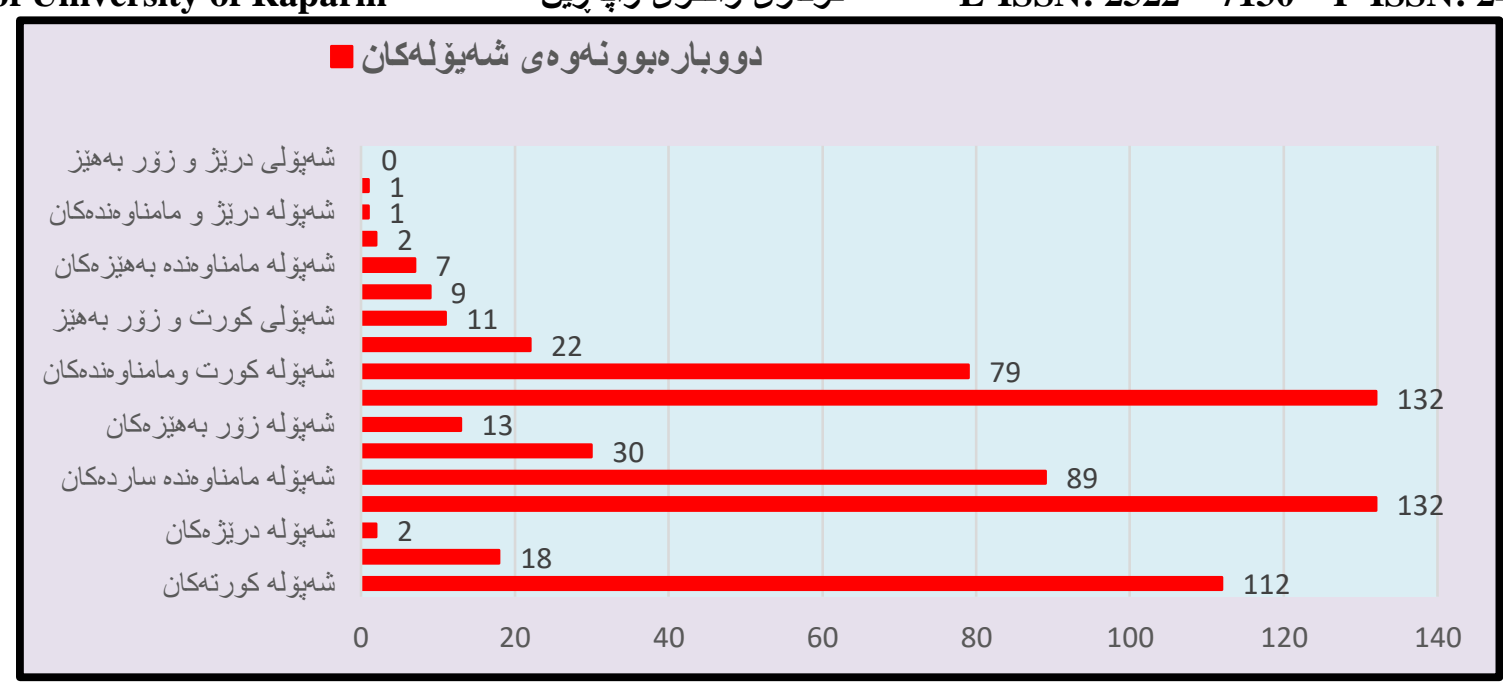

سهرجاوه: كارى تويزّهر، بشت بهست به خشتهى (9).

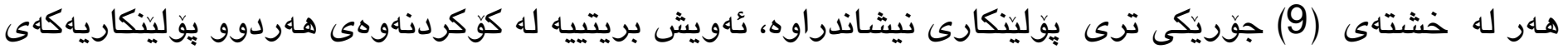

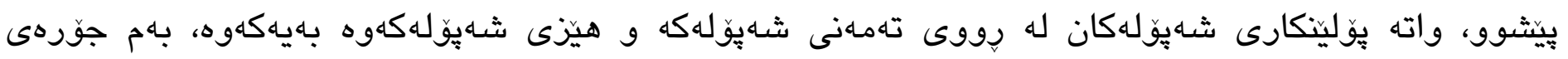
خواردوه:

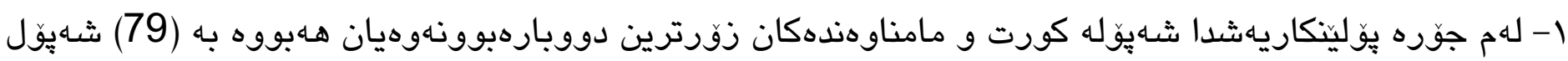

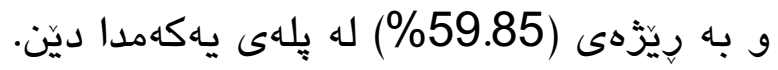

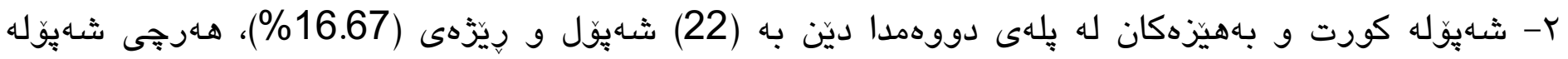

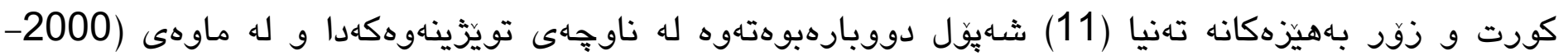

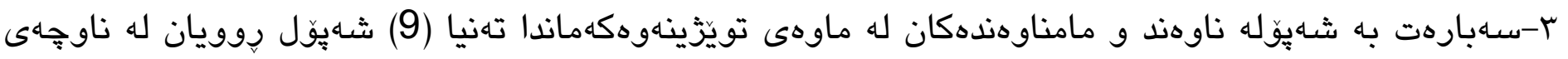

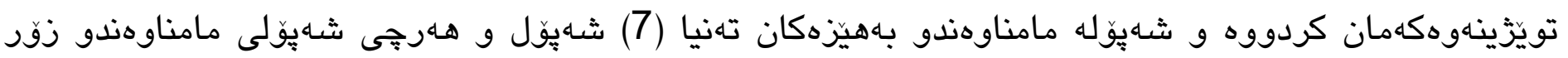

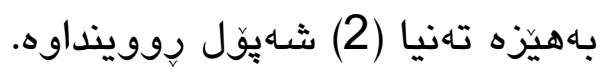

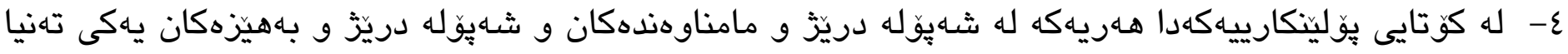

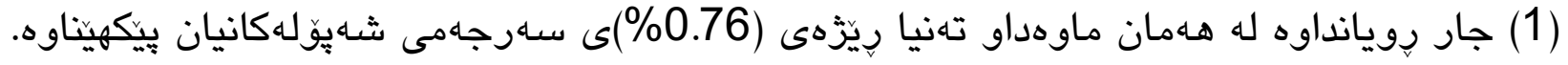

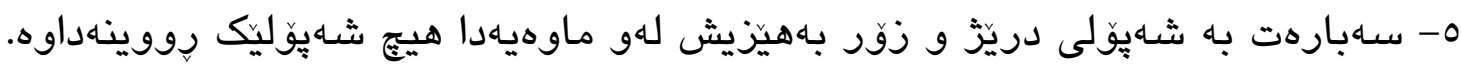

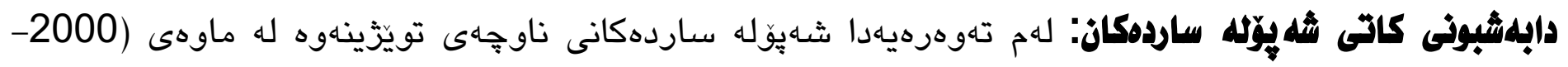

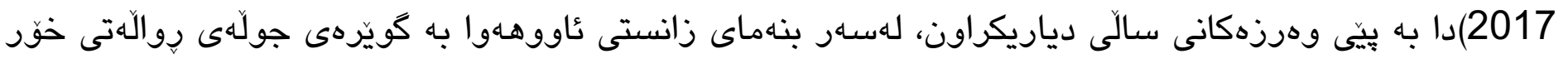

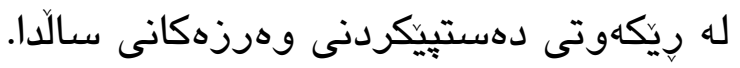

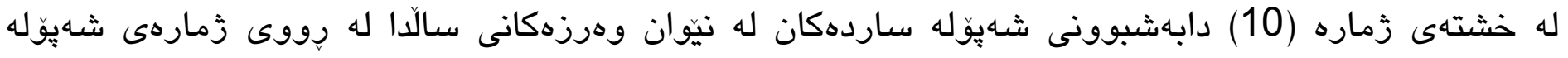

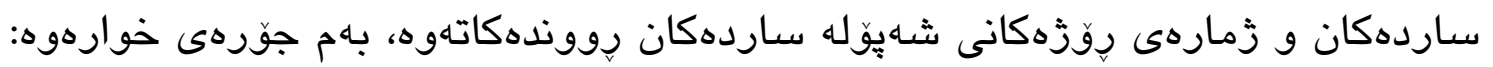




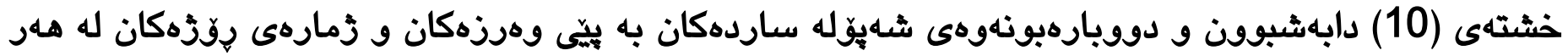

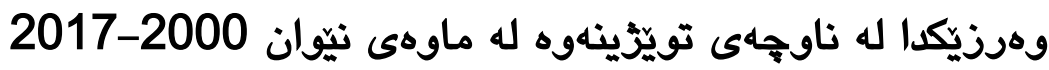

\begin{tabular}{|c|c|c|c|c|c|}
\hline \multicolumn{2}{|c|}{ دووبارهبوونهوهى رِّذهكانى شـاهيوله } & \multicolumn{2}{|c|}{ دووبارهبوونهوهى شـهيوله ساردهكان } & \multirow{2}{*}{ وهرز } & \multirow{2}{*}{$\dot{j}$} \\
\hline دووبارهبونهوه ريّزَى \% & دووبارهبونهوه & دوباردبونهوه رِيَّى & دووبارهبونهوه & & \\
\hline 23.4 & 124 & 26.51 & 35 & 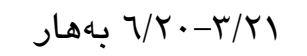 & 1 \\
\hline 6.03 & 32 & 6.82 & 9 & ا & r \\
\hline 28.5 & 151 & 25.76 & 34 & 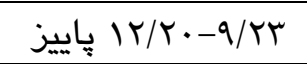 & $r$ \\
\hline 42.07 & 223 & 40.91 & 54 & | & $\varepsilon$ \\
\hline 100 & 530 & 100 & 132 & تيكرِا (سهرجهم) & \\
\hline
\end{tabular}

سهرجاوه: كارى تويّزّهر، بشت بهست به باشكوى زُماره (1).

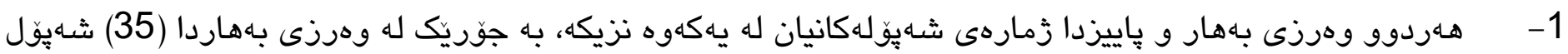

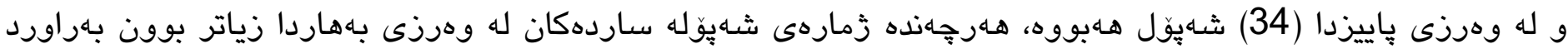

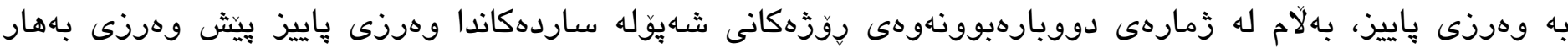

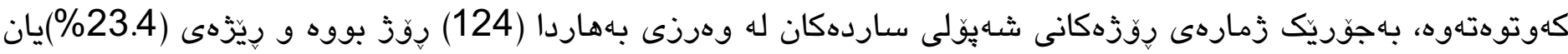

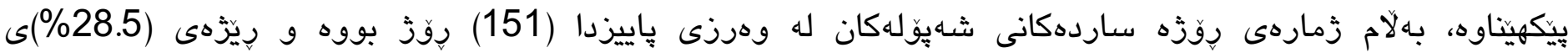

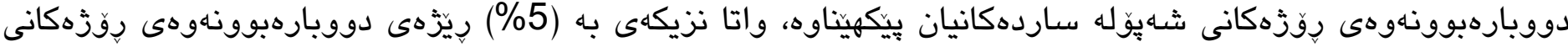

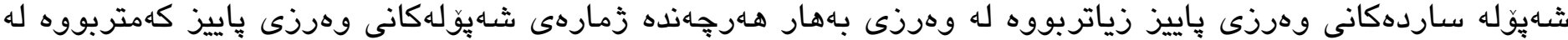

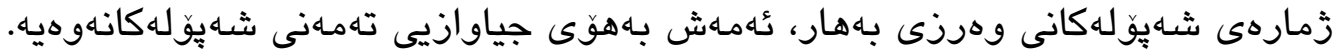

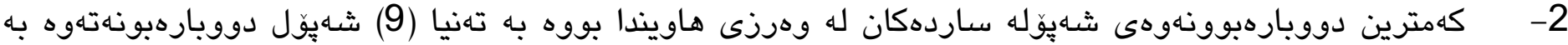

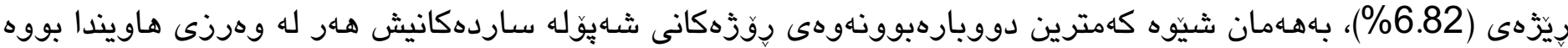

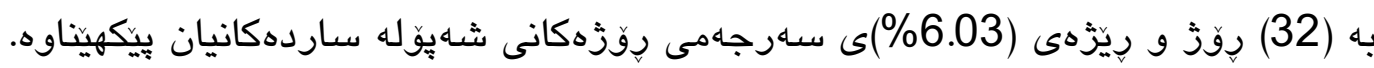

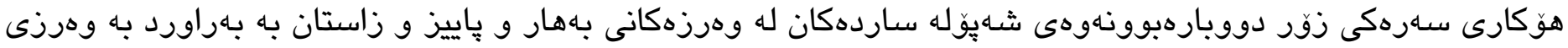

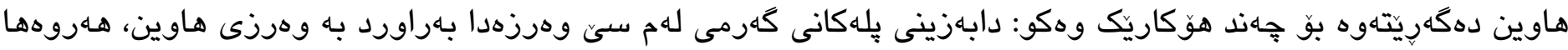

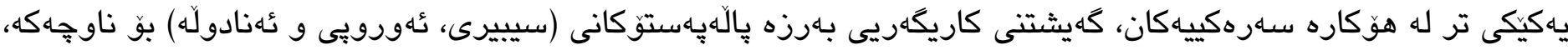

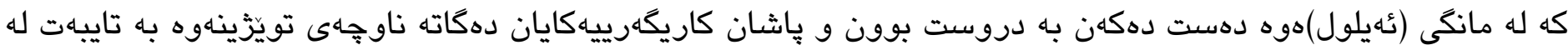

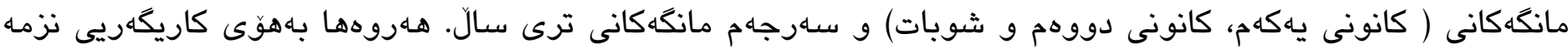

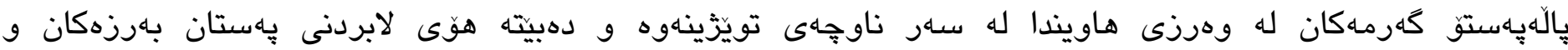

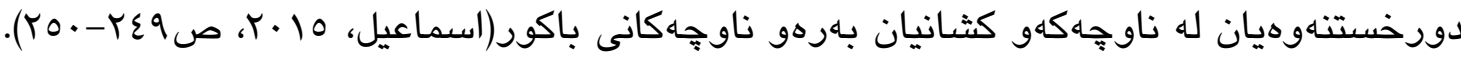

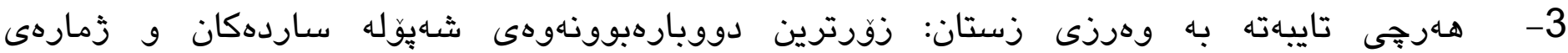

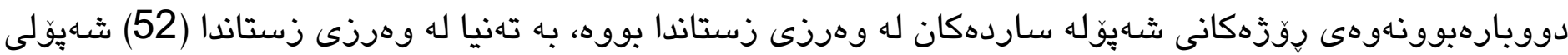

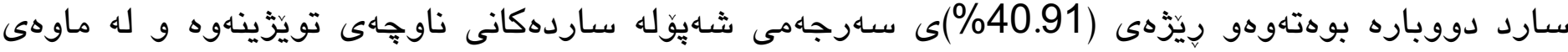

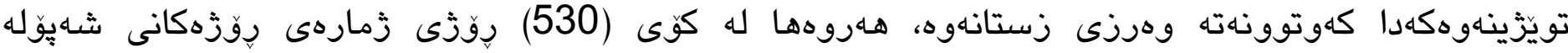




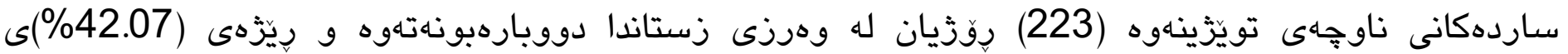

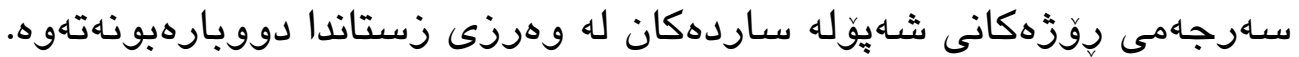

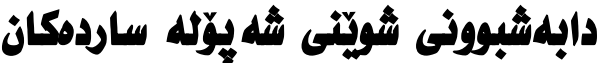

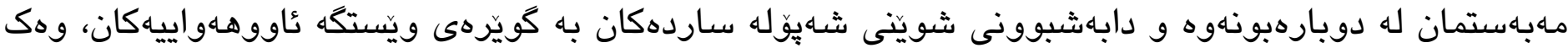

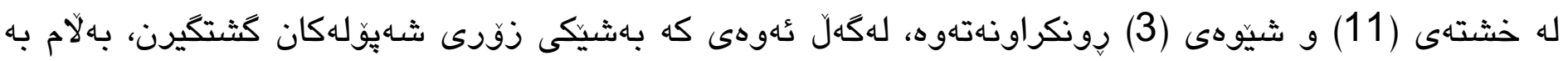

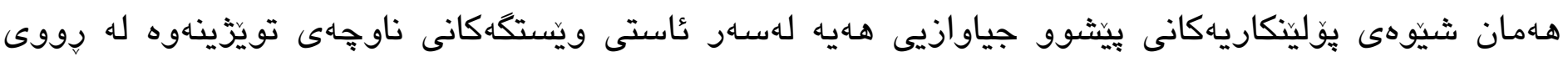

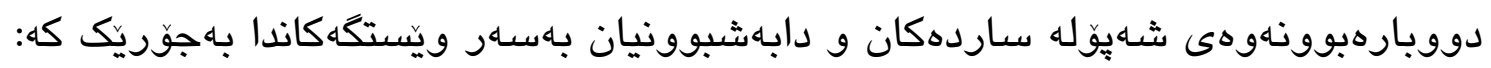

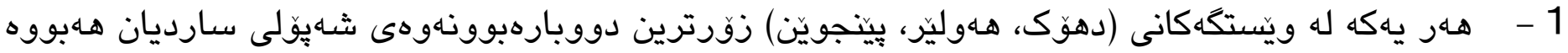

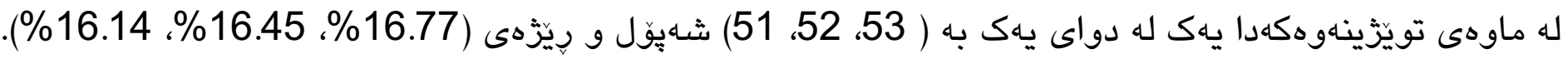

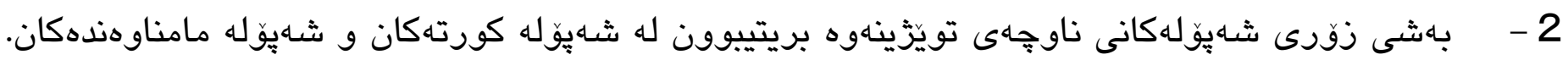

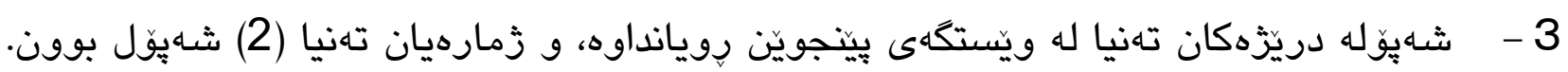

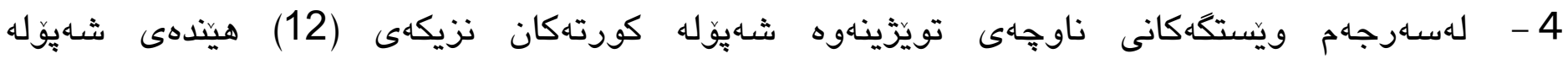

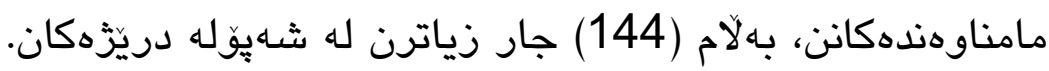

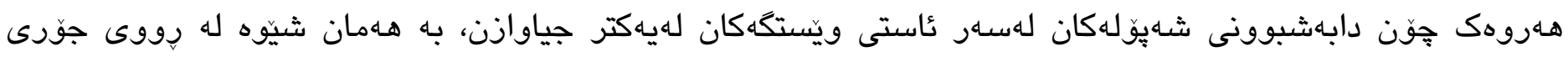

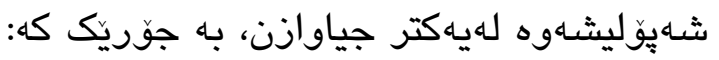

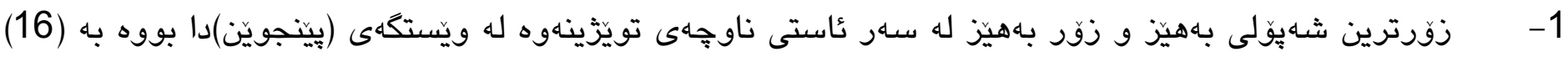

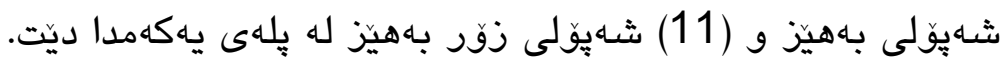

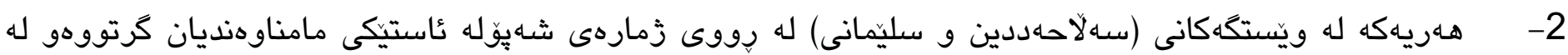

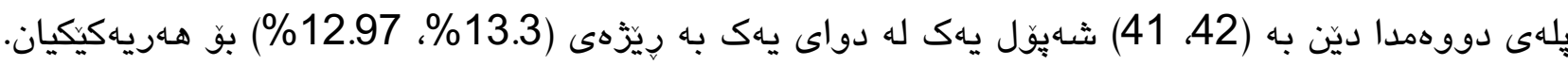

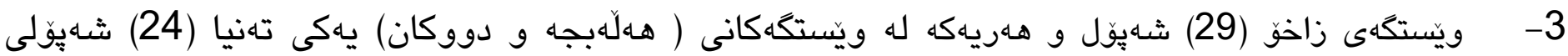

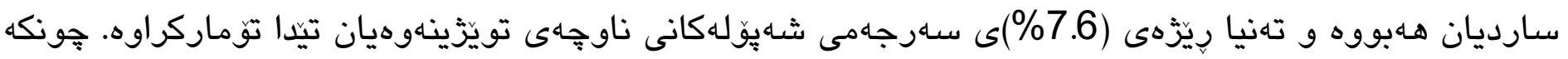

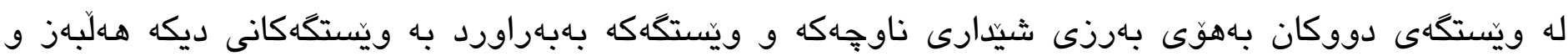

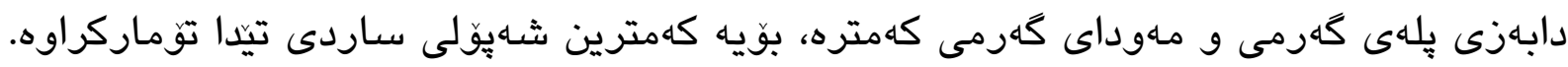

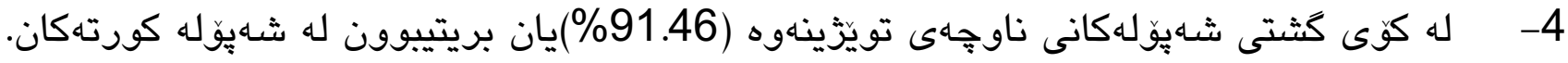

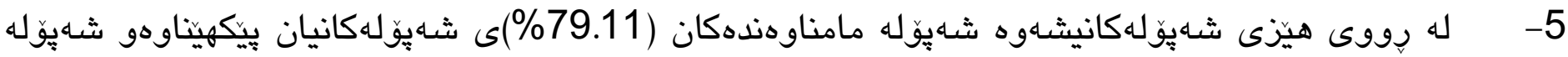

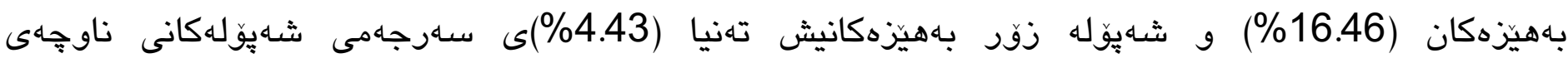

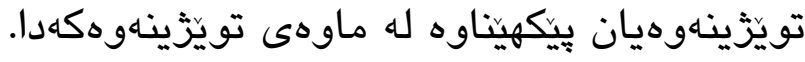

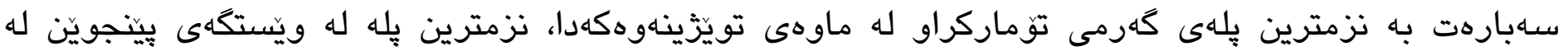

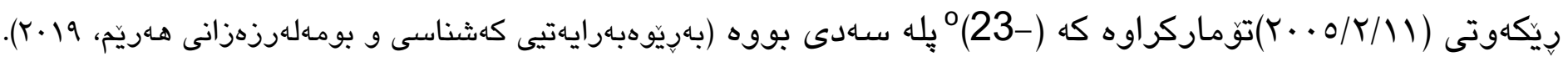

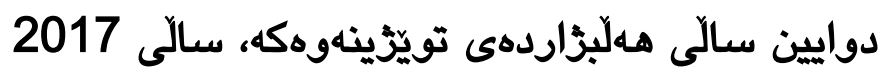

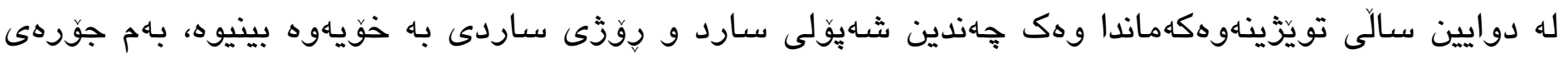
خوارهوه: (1) 


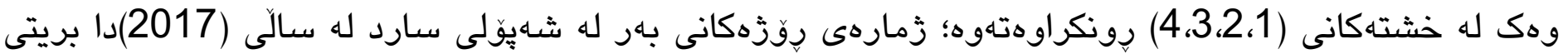

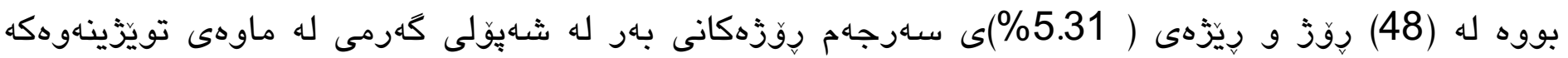

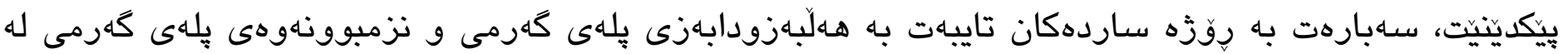

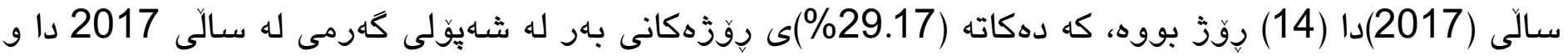

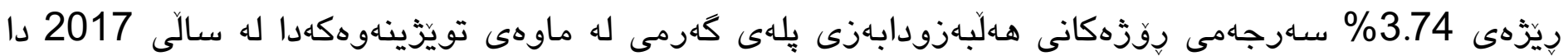

$$
\text { بووه. سـاهبارهت بـ بهد }
$$




\section{Journal of University of Raparin $\quad$ كوّقارى زانكوّى رابِهرين $\quad$ E-ISSN: 2522 - 7130 P-ISSN: 2410 - 1036}

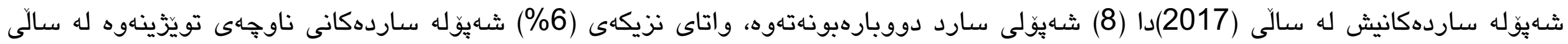

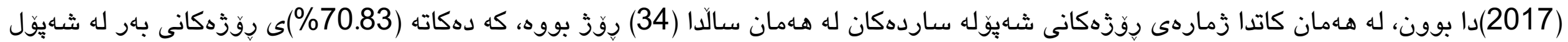

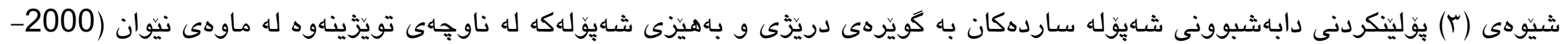
(2017

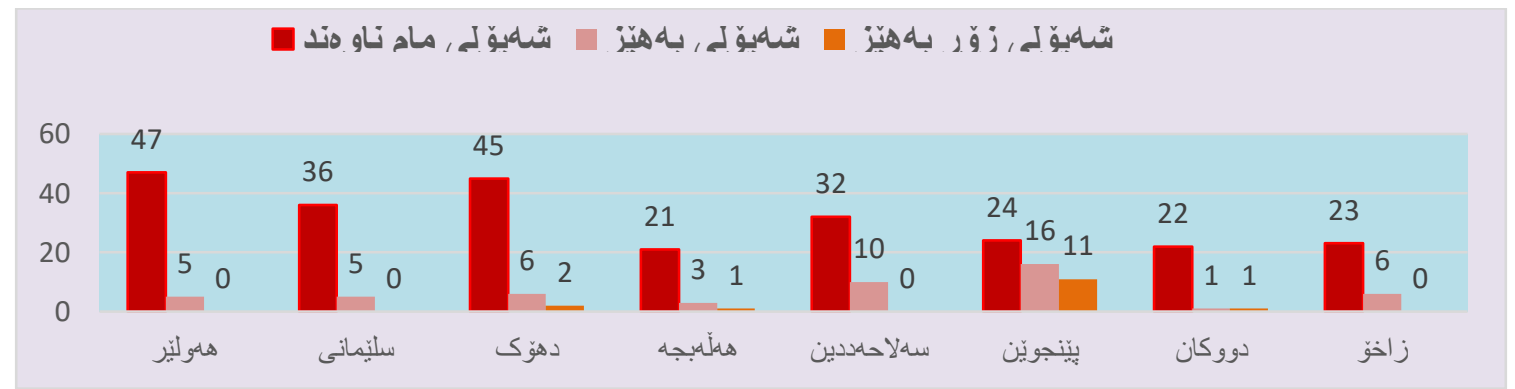

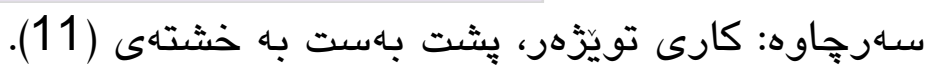

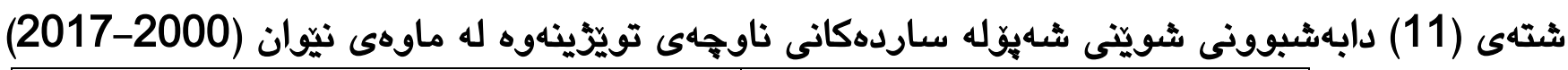

\begin{tabular}{|c|c|c|c|c|c|c|c|c|c|}
\hline \multirow[b]{2}{*}{ 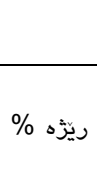 } & \multicolumn{4}{|c|}{ يَّولينكارى شهيقِلهكان له بِوى هيَزهوه } & \multicolumn{3}{|c|}{ يُولينكارى شهيقولهكان له بِووى ماوهى مانهوهيان } & \multirow[b]{2}{*}{ بهورى بهى له دهاستى } & \multirow[b]{2}{*}{ ناوى ويّستكه } \\
\hline & 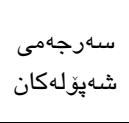 & شهوِلى زقور بههيّز & شهاهيقلى & مامناوهند & دريّزَهـانوله & مامناوهنديهكان & شهيوله كورتهكان & & \\
\hline 16.45 & 52 & & 5 & 47 & & 2 & 50 & 470 & هـوليّز \\
\hline 12.97 & 41 & & 5 & 36 & & 5 & 36 & 884.8 & 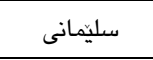 \\
\hline 16.77 & 53 & 2 & 6 & 45 & & 6 & 47 & 569 & دهؤك \\
\hline 7.6 & 24 & & 3 & 21 & & 3 & 21 & 695 & هـلةبجه \\
\hline 13.3 & 42 & & 10 & 32 & & 1 & 41 & 1088 & سه لاحهددين \\
\hline 16.14 & 51 & 11 & 16 & 24 & 2 & 4 & 45 & 1309 & بينجنوينَ \\
\hline 7.6 & 24 & 1 & 1 & 22 & & 2 & 22 & 690 & دووكان \\
\hline \multirow[t]{3}{*}{9.17} & 29 & & 6 & 23 & & 2 & 27 & 443.8 & زاخّ \\
\hline & 316 & 14 & 52 & 250 & 2 & 25 & 289 & \multicolumn{2}{|c|}{ كوى كثتى } \\
\hline & 100 & 4.43 & 16.46 & 79.11 & 0.63 & 7.91 & 91.46 & \multicolumn{2}{|c|}{ ب بِيَّه \% } \\
\hline
\end{tabular}

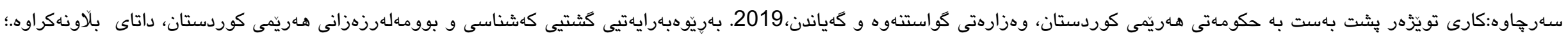

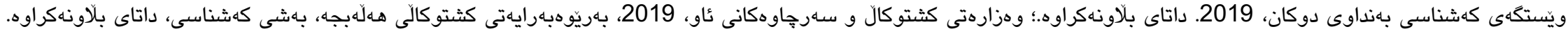

DOI:https://doi.org/10.26750/Vol(8).No(2).Paper_14 http://journal.uor.edu.krd/index.php/JUR Vol.8. No.2,June.2021 


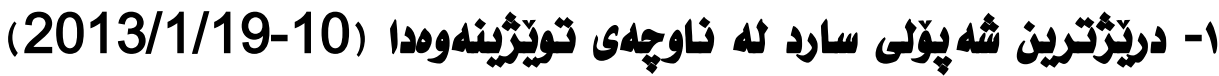

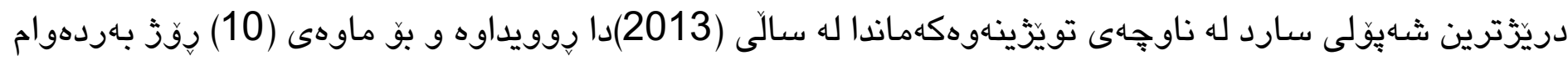

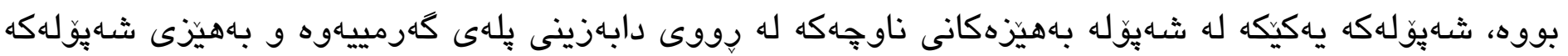

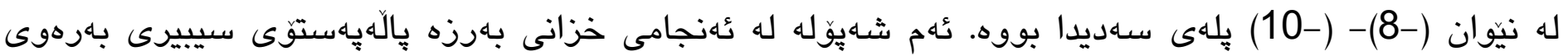

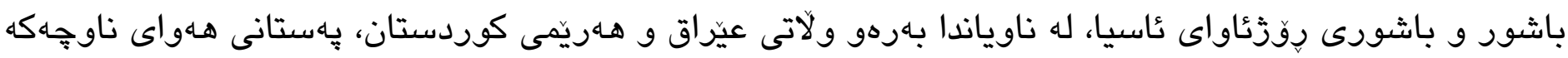

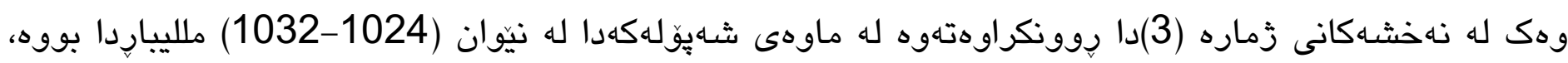

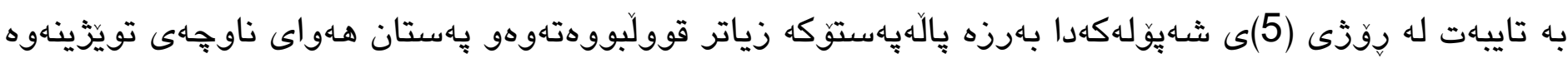

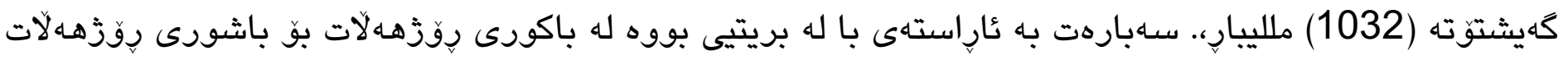

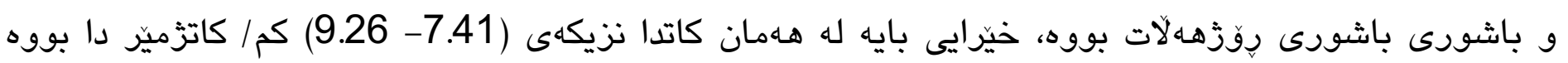

(PSWC, 2020)

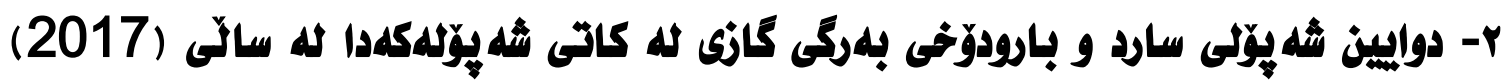

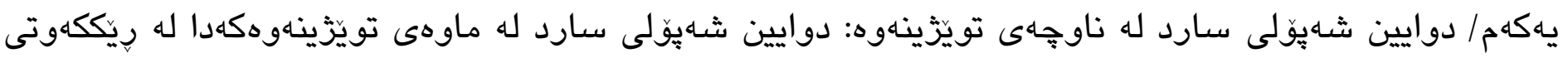

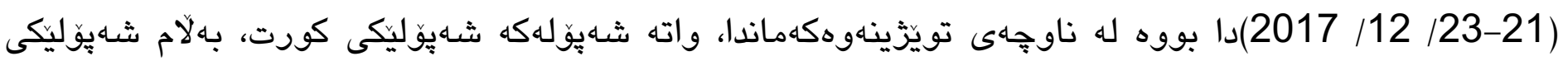

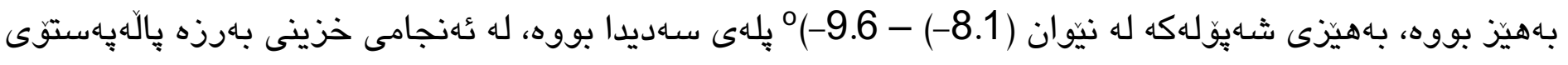

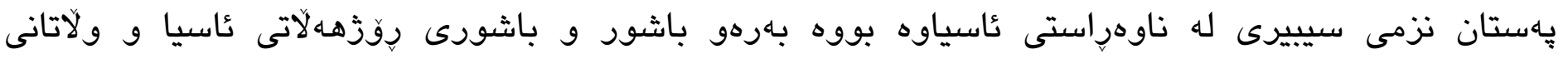

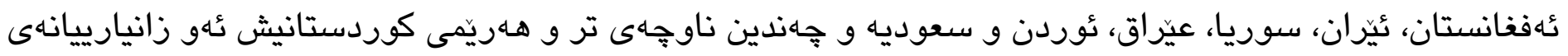

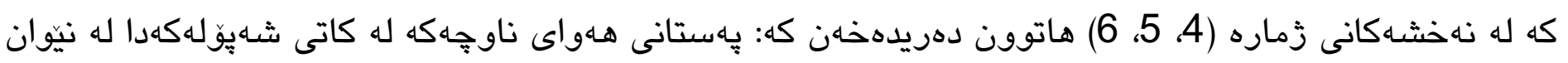

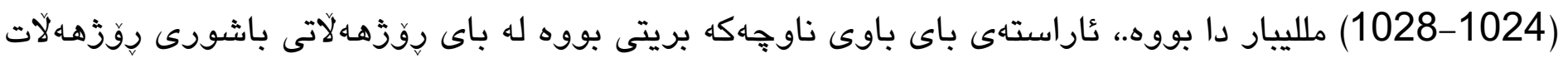

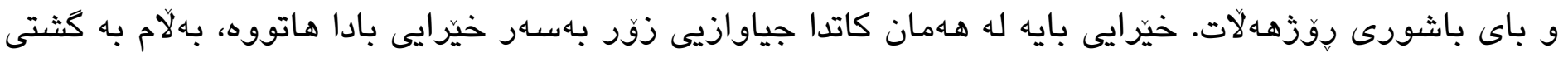

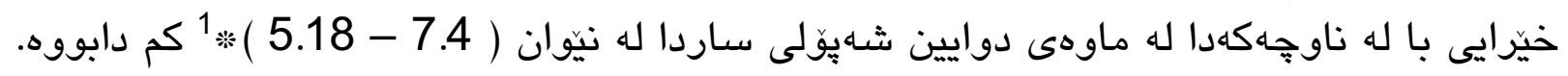

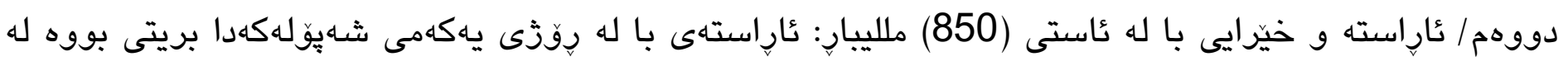

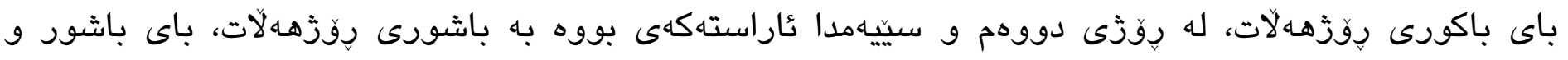

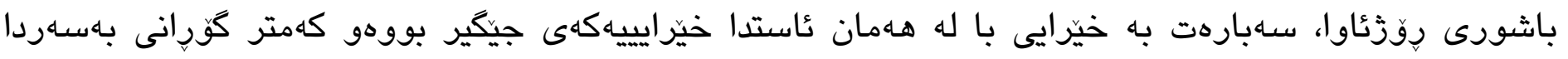

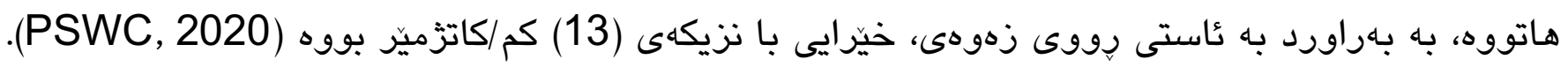

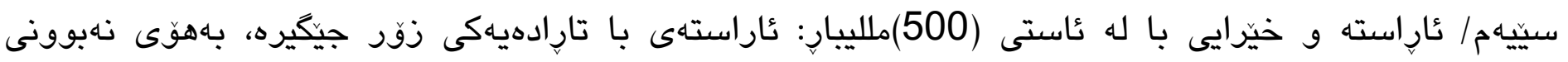

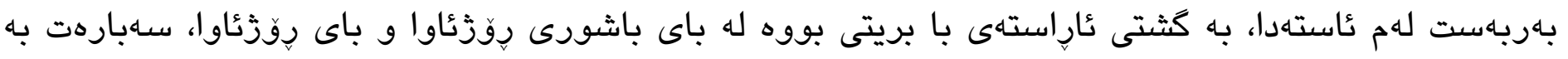

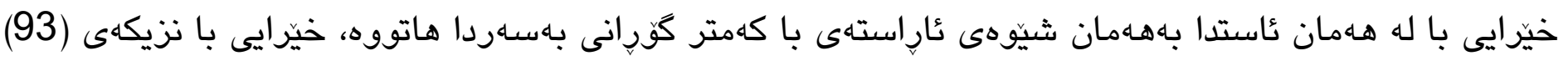

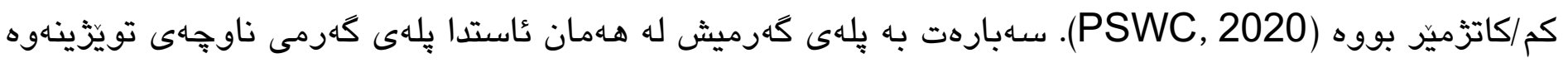

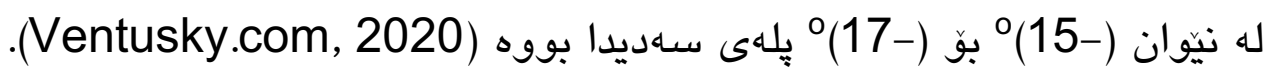

$1 * 1 \mathrm{Knot}(\mathrm{knt})=1.852 \mathrm{Km} / \mathrm{hou}$ 
نهخشهانى (3)نهخشهانى بهاستانى هـوا له كاتى شهيَّلى سارد له ناوجهى تويّزينهوه له ماوهى (10-2013/1/19)

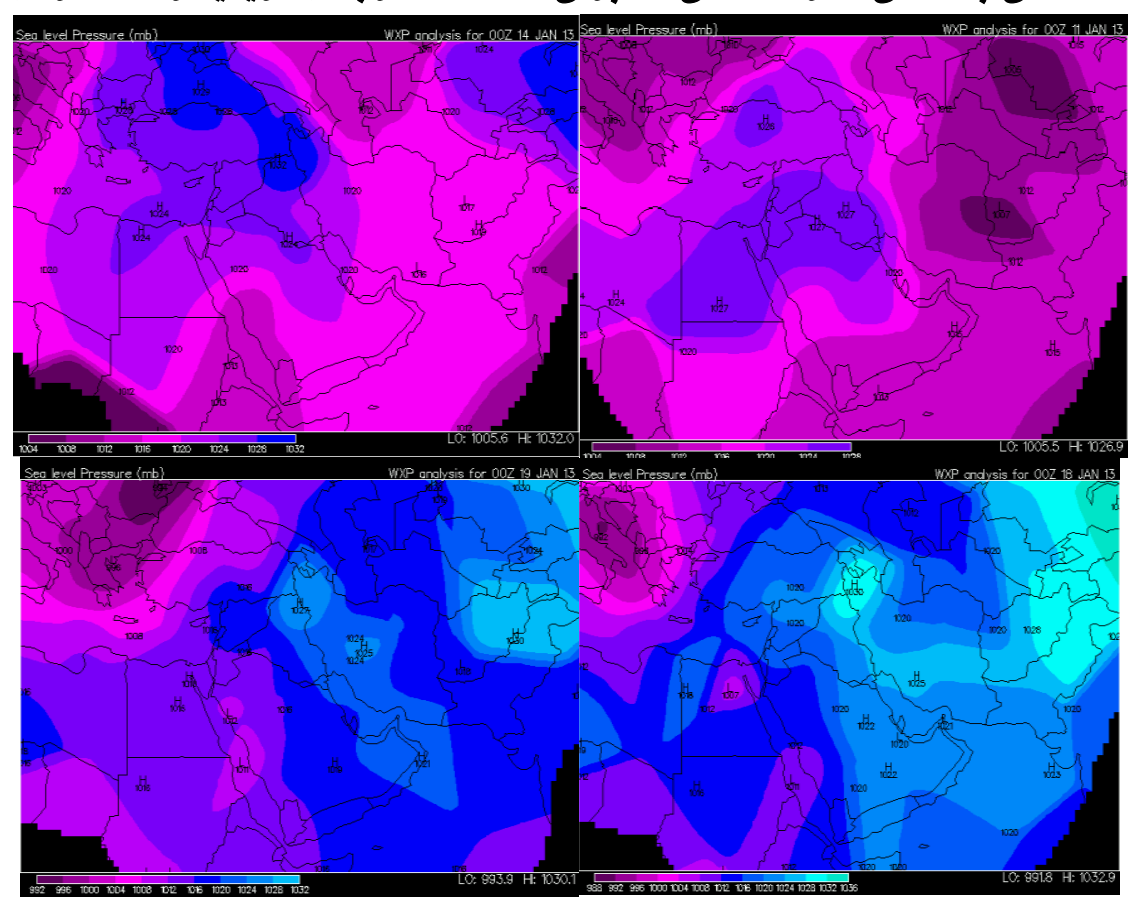

https://vortex.plymouth.edu [Accessed 18 August 2020 ] سهارجاوه:

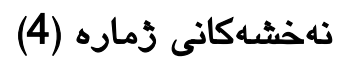

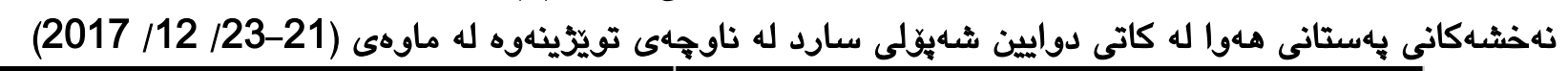

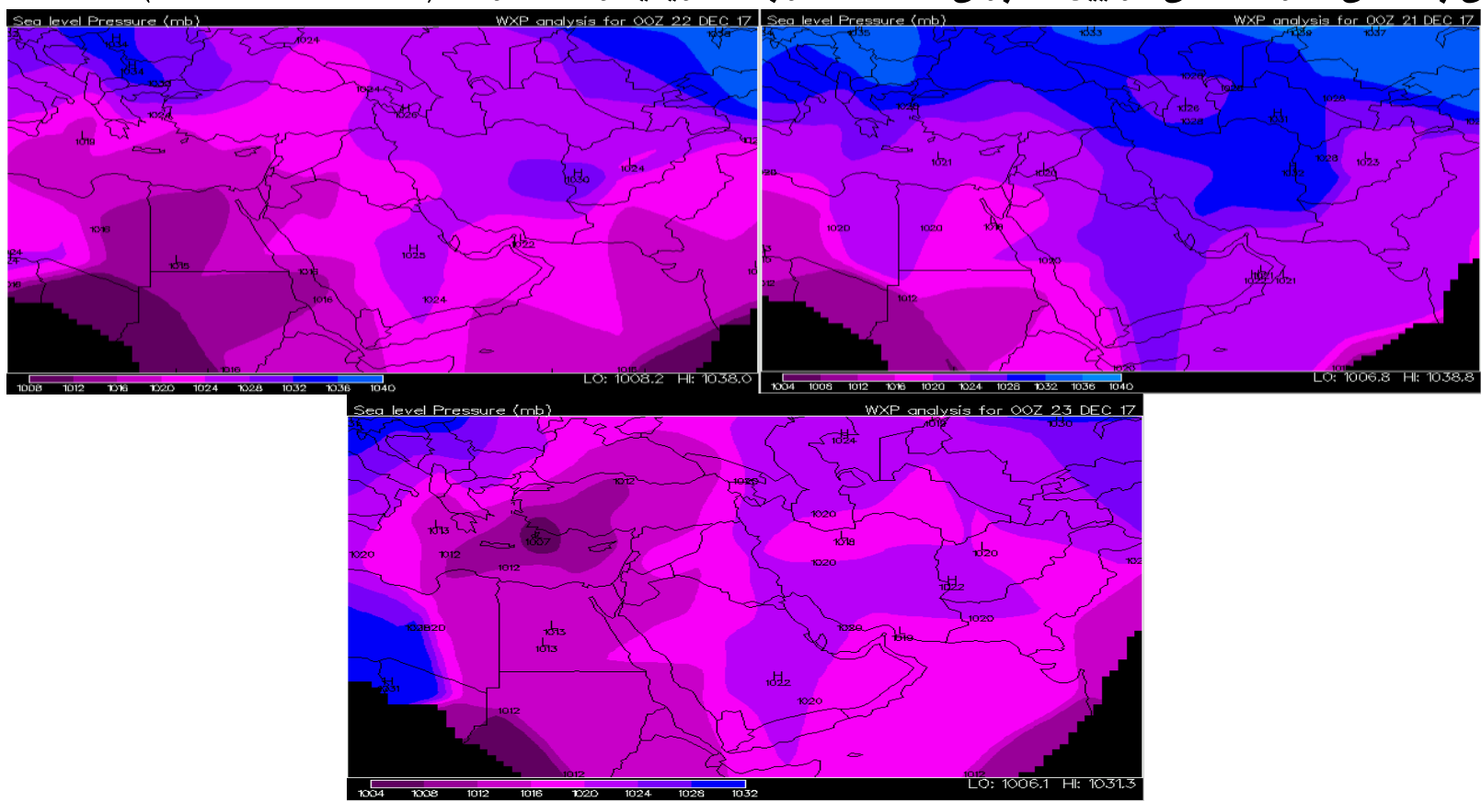

https://vortex.plymouth.edu [Accessed 18 August 2020 [ سهرجاوه: 


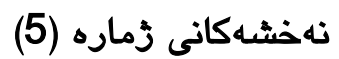

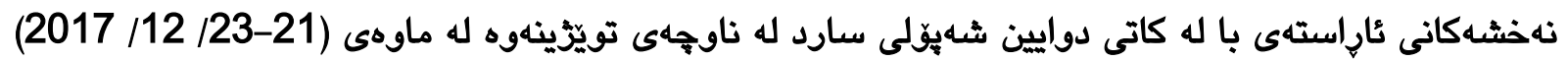
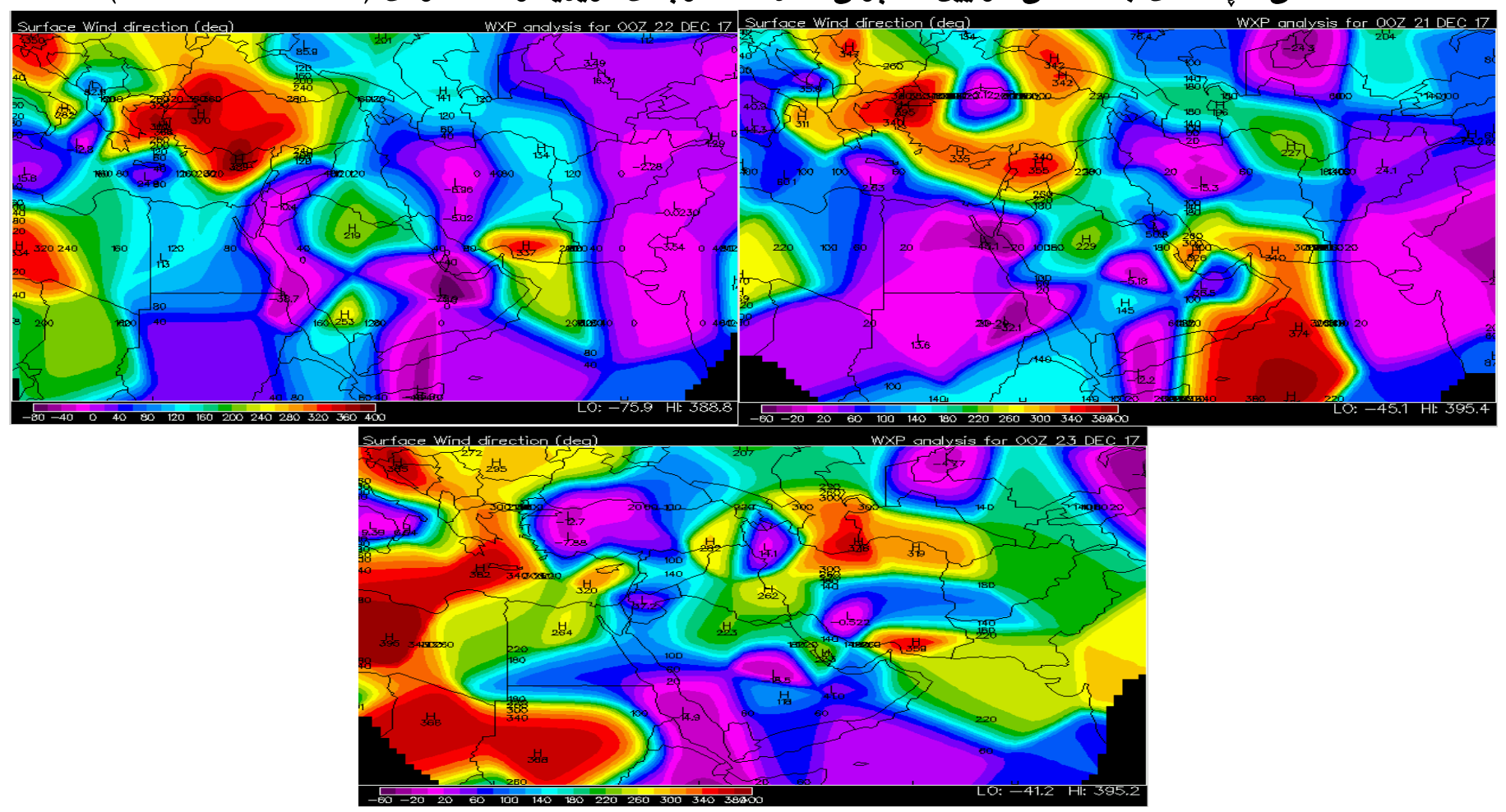

https://vortex.plymouth.edu [Accessed 18 August 2020 ] سهرجاوه

نهخشهانى زماره (6)نهخشهانى خيّرايى با له كاتى دوايين شهيولى سارد له ناوجهى تويزّزينهوه له ماوهى (21-23/ 12/ 2017) 


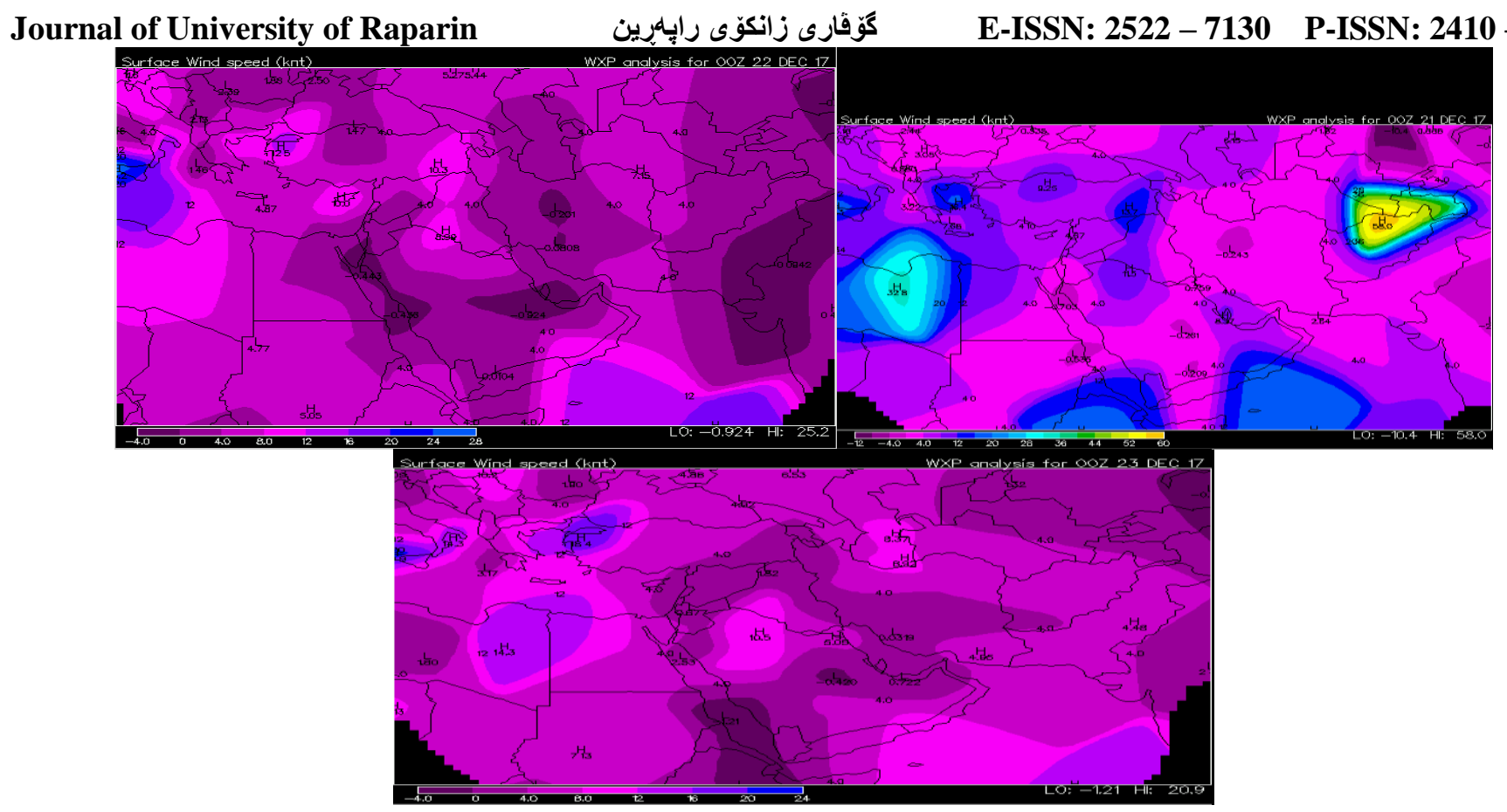

https://vortex.plymouth.edu [Accessed 18 August 2020 ]: سهرجاوه

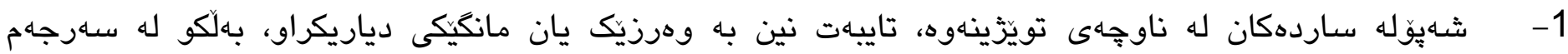

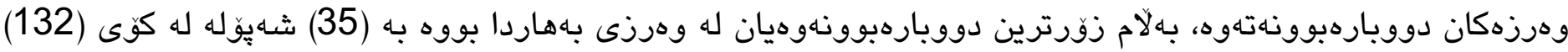

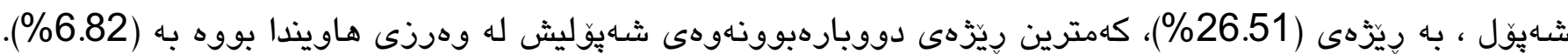

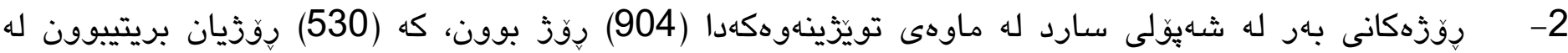

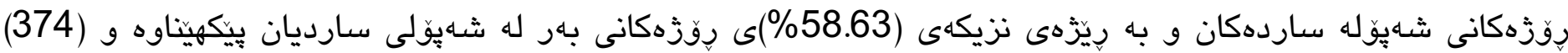

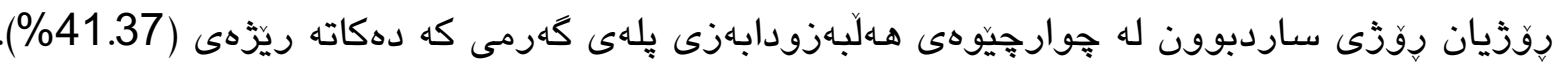

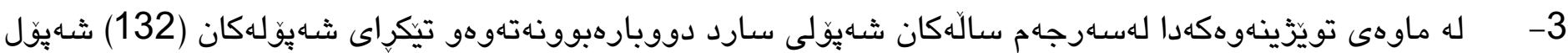

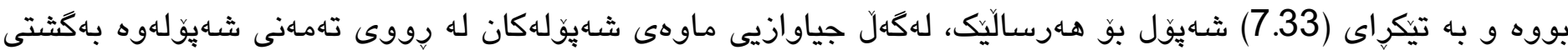

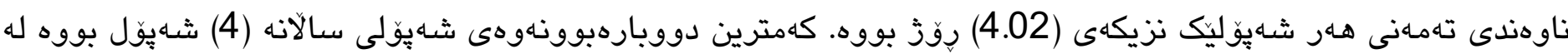

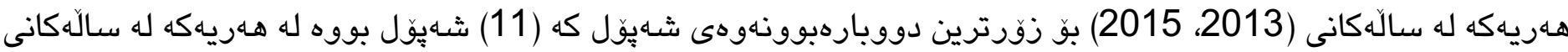
2014، 2004)

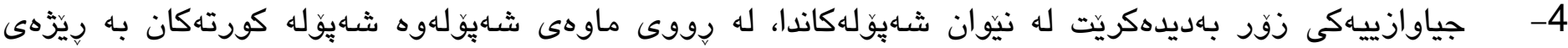

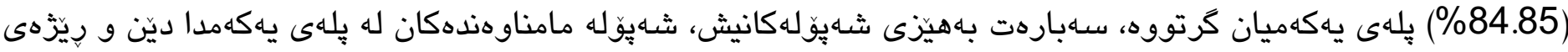
(567.42)

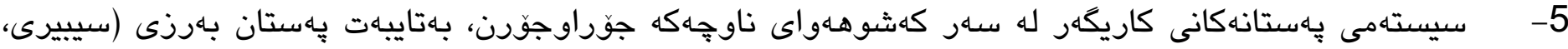

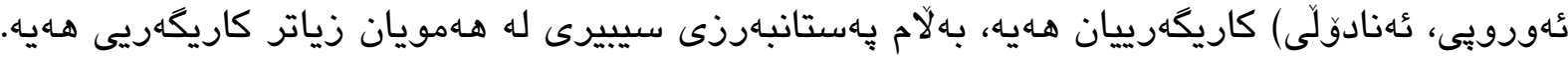




\title{
Geographical Analysis of Repeat Cold Waves in Kurdistan Region for the Period 2000-2017
}

\section{Luqman Wsw Omer}

Geography Department, Faculty of Education, University of Koya, Koya, Kurdistan Region, Iraq. E-mail: luqman.omer@koyauniversity.org

\section{Mohammed Qader Rasool}

Geography Department, College of Humanities, University of Raparin, Rania, Kurdistan Region, Iraq.

E-mail: muhammad-q81@uor.edu.krd

\begin{abstract}
:
In this paper, we investigated changes in cold waves in Kurdistan region over the period 20002017. Cold waves it means decrease $5^{\circ} \mathrm{c}$ minimum temperature degree at least from the average monthly minimum temperature for this month and continues for 3 days consecutive at least. The study found 132 cold waves repeat in Kurdistan region, that is 112 waves were the type of shortwave it means \%84.85 of them were shortwaves, 18 waves medium and only 2 waves were the type of long waves. About severity of the temperature of cold waves the study also, found different types, for example in all cold waves about $\% 67.42$ or 89 waves were from the type of moderate waves, 30 waves strong and 13 waves were extreme. About of the cold days over the period of time include 904 threshold cold waves, in this number 530 days were in the type of the cold day of cold waves, and 374 days were the Temperature fluctuation of cold days. As well as the paper found that the annual repetition cold waves vary from month to month, and the season to season, it was found that cold waves were highest in spring and lowest in summer. The most geographical distribution of system atmospheric pressure effect on the weather and cold waves in study area is The Siberian Heights.
\end{abstract}

Keywords: Threshold Waves ‘Cold Waves, Temperature Fluctuation, Climatic Fluctuation. 


\section{Journal of University of Raparin}

كوَّقارى زانكوّى رابِّرين

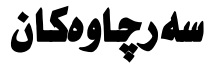

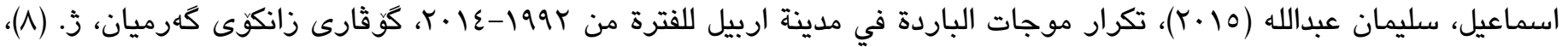
ISSN: 2310-0087

$$
\text { بهريّوهبهرايهتى بهست و بهنداوى دووكان، ويِستكهى كهشناسى بهنداوى دوكان، } 19 \text { •r. داتاى بلاّونهكراوه. }
$$

العوابد، كريم دراغ محمد، الموقع الفلكي والجغرافي للعراق وأثره فى تعرضه الى ظواهر جوية قاسية في مناخه، مجلة البحوث الجغرافية،

الضاحي، حارث عبدالجبار حميد، 9 ال ـ الأمطار في العراق: دراسة في المناخ التطبيقي، رسالة الماجستير، جامعة الإسكندرية، الإسكندرية.

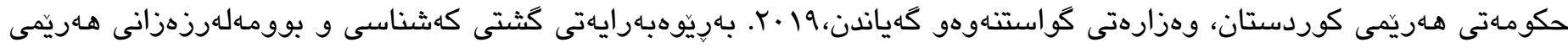

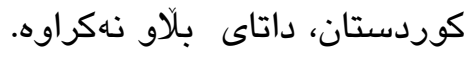

$$
\text { مغايري، مازن (بدون سنة الطبع)، اطلس العالم، المكتبة الجامعية. }
$$

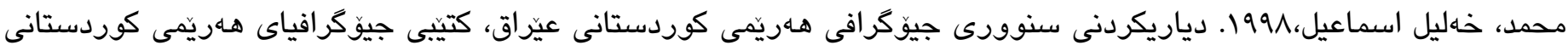

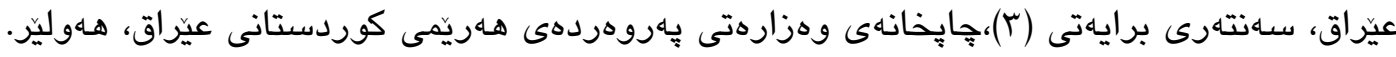

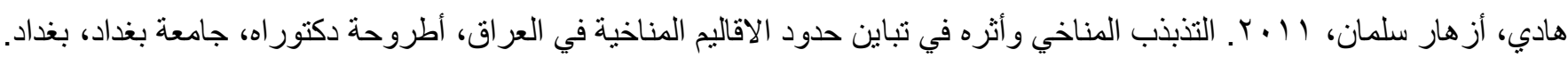
كاظم، احلام عبدالجبار، ا (9 1 ـ الكثل الهو ائية، تصنيفها، خصائصها: در اسة تطبيقيه على مناخ العراق، اطروحة دكتور اه، جامعة بغداد، بغداد.

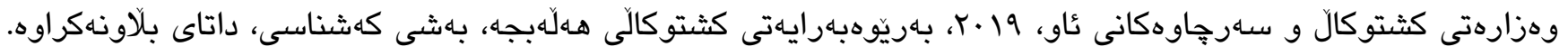

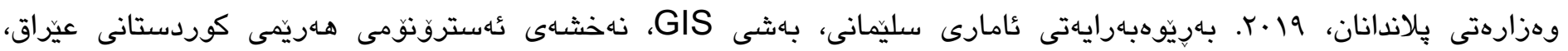
بلاّونهكراوه.

Dholakia, H.H., Garg, A. (2014), A Tale of five cities heat waves, cold spells and mortality risk in urban India, Indian institute of management Ahmadabad, India-380015, research and publication, W.P.No.2014-10-02.

IPCC, 2013: Climate Change 2013: The Physical Science Basis. Contribution of Working Group I to the Fifth Assessment Report of the Intergovernmental Panel on Climate Change On the Measurement of Heat Waves,JOURNAL OF CLIMATE VOLUME 26,p 4515, Cambridge university press.

Labajo, A. et al. (2014), Definition and temporal evolution of the heat and cold waves over the Spanish central plateau from 1961 to 2010 , atmosfera 27 (3).

Micu,D.(2012), Cold Wave in the Romanian Carpathians - An Indicator of Negative Temperature Extremes, available at: http://aerapa.conference.ubbcluj.ro/2012/pdf/13\%20D\%20Micu.pdf Accessed on 14-5-2019.

Shabbar, A. and Bonsal, B. (2003), An Assessment of changes in winter cold and warm spells over Canada, Kluwer academic publishers, Netherlands.

uz-Zaman ch., R. (2009), Climate change indicators of Pakistan, technical report No. PMD-22.

WMO (2013), The global climate 2001-2010 A decade of climate extremes, summary report, wmo-no.1119.

https://vortex.plymouth.edu [Accessed 18 June 2020 ].

https://www.ventusky.com [Accessed 24 June 2020]. 
يويككهوتى شهيوله ساردهان له ناوجهى تويزّينهوه له ماوهى نيوان (2000-2017)

\begin{tabular}{|c|c|c|c|c|c|c|c|c|c|c|c|}
\hline 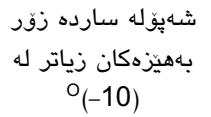 & 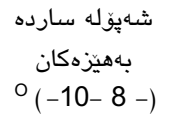 & 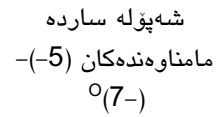 & زَّمارهى & بهروار & 3 & 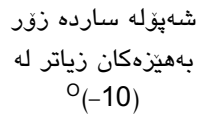 & 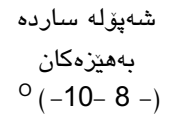 & 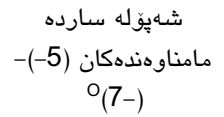 & زؤزمارهان & بهروار & 3 \\
\hline \multirow{7}{*}{$-10.7-10.2-$} & & & 5 & $2002 / 12 / 27-23$ & 24 & & & $-5.7-5.2-$ & 3 & $2000 / 1 / 18-16$ & 1 \\
\hline & $-10-9.8-$ & & 3 & $2003 / 1 / 3-1$ & 25 & & & $-6-5.4-$ & 3 & $2000 / 2 / 9-7$ & 2 \\
\hline & & $-5.3-5-$ & 3 & $2003 / 3 / 30-28$ & 26 & & & $-5.4-7.1-$ & 3 & $2000 / 3 / 10-8$ & 3 \\
\hline & & $-7.7-5.2-$ & 3 & $2003 / 5 / 3-1$ & 27 & & & $-7.6-5.2-$ & 3 & $2000 / 7 / 3-1$ & 4 \\
\hline & & $-7.9-5.6-$ & 3 & $2003 / 5 / 10-8$ & 28 & & $-8.1-8$ & & 3 & $2000 / 8 / 31-29$ & 5 \\
\hline & & $-7.9-5.2-$ & 6 & $2003 / 6 / 6-1$ & 29 & & $-8.3-8$ & & 7 & $2000 / 10 / 11-5$ & 6 \\
\hline & & $-6.5-5$ & 6 & $2003 / 9 / 6-1$ & 30 & & & $-7.3-6.2$ & 3 & $2000 / 10 / 26-24$ & 7 \\
\hline \multirow[t]{13}{*}{$-11.2-10.9-$} & & & 3 & $2003 / 10 / 31-29$ & 31 & & & $-6.3-5-$ & 4 & $2000 / 12 / 23-20$ & 8 \\
\hline & & $-6.2-5-$ & 6 & $2003 / 11 / 19-14$ & 32 & & & $-5-5$ & 3 & $2001 / 1 / 31-29$ & 9 \\
\hline & & $-7.2-5-$ & 4 & $2003 / 11 / 24-21$ & 33 & & $-8.3-8-$ & & 4 & $2001 / 2 / 24-21$ & 10 \\
\hline & & $-6.6-5.2-$ & 3 & $2004 / 1 / 18-16$ & 34 & & & $-7.1-6-$ & 6 & $2001 / 10 / 25-20$ & 11 \\
\hline & & $-7.2-5.1-$ & 3 & $2004 / 2 / 18-16$ & 35 & & & $-7.5-6.8$ & 3 & $2001 / 10 / 31-29$ & 12 \\
\hline & $-10-8$ & & 3 & $2004 / 2 / 25-23$ & 36 & & & $-6.8-5.7-$ & 7 & 2001/11/25-19 & 13 \\
\hline & & $-7.8-6.8-$ & 4 & $2004 / 3 / 19-16$ & 37 & & & $-7.9--5.2$ & 3 & $2001 / 12 / 23-21$ & 14 \\
\hline & $-10-8.1-$ & & 4 & $2004 / 4 / 8-5$ & 38 & & & $-7.7-6.7-$ & 3 & $2002 / 1 / 15-13$ & 15 \\
\hline & & $-7.4-5.9$ & 3 & $2004 / 5 / 4-2$ & 39 & $-17.4-11.4$ & & & 4 & $2002 / 1 / 28-25$ & 16 \\
\hline & & $-6.8-5.8-$ & 3 & $2004 / 6 / 3-1$ & 40 & & & $-7.9-5.2-$ & 10 & $2002 / 2 / 10-1$ & 17 \\
\hline & $-10-8.5$ & & 3 & $2004 / 9 / 22-20$ & 41 & & & $-7.9-5.3$ & 5 & $2002 / 2 / 21-17$ & 18 \\
\hline & & $-5.5-5$ & 3 & $2004 / 10 / 24-22$ & 42 & & & $-7.4-5.4-$ & 3 & $2002 / 3 / 3-1$ & 19 \\
\hline & $-8.9-8$ & & 4 & $2004 / 11 / 26-23$ & 43 & & & $-6.8-5-$ & 3 & $2002 / 4 / 5-3$ & 20 \\
\hline$-11.7-10.2$ & & & 3 & $2004 / 11 / 30-28$ & 44 & & & $-6.8-5.1-$ & 3 & 2002/6/4-2 & 21 \\
\hline$-13.9-10.1-$ & & & 5 & $2005 / 1 / 30-26$ & 45 & & & $-5.6-5$ & 3 & $2002 / 10 / 24-22$ & 22 \\
\hline \multirow[t]{3}{*}{$-15-10.2-$} & & & 8 & $2005 / 2 / 17-10$ & 46 & & & $-6.1-5.4$ & 3 & $2002 / 12 / 15-13$ & 23 \\
\hline & $-9.9-8.2-$ & & 3 & $2009 / 9 / 30-28$ & 79 & & & $-7.7-5.3$ & 3 & $2005 / 3 / 26-24$ & 47 \\
\hline & & $-7.9-5.4$ & 3 & $2009 / 11 / 24-22$ & 80 & & $-8.2-8$ & & 4 & $2005 / 4 / 7-4$ & 48 \\
\hline \multirow[t]{5}{*}{$-14.5-10.1-$} & & & 4 & $2010 / 1 / 29-26$ & 81 & & $-9.8 \mathrm{~s}-8.4$ & & 5 & 2005/5/7-3 & 49 \\
\hline & $-10-8.1-$ & & 4 & $2010 / 2 / 8-5$ & 82 & & $-9.8-8.3-$ & & 7 & $2005 / 10 / 26-20$ & 50 \\
\hline & $-9.3-8.3$ & & 6 & $2010 / 5 / 7-2$ & 83 & & $-9.9-8.9$ & & 4 & $2005 / 10 / 31-28$ & 51 \\
\hline & & $-5.5-5.2$ & 3 & 2010/7/3-1 & 84 & & $-9.5-9$ & & 6 & $2005 / 12 / 31-26$ & 52 \\
\hline & & $-6-5$ & 3 & $2010 / 10 / 14-12$ & 85 & $-13.6-12.1-$ & & & 3 & $2006 / 1 / 19-17$ & 53 \\
\hline \multirow[t]{3}{*}{$-16-11-$} & & & 7 & $2011 / 1 / 25-19$ & 86 & & & $-6-5.9$ & 3 & 2006/2/19-17 & 54 \\
\hline & & $-5.5-5$ & 6 & $2011 / 2 / 7-2$ & 87 & & $-8.7-8.2-$ & & 3 & $2006 / 3 / 13-11$ & 55 \\
\hline & & $-7.9-6.6-$ & 4 & $2011 / 4 / 16-13$ & 88 & & & $-5.5-5$ & 3 & $2006 / 5 / 6-4$ & 56 \\
\hline
\end{tabular}


Journal of University of Raparin

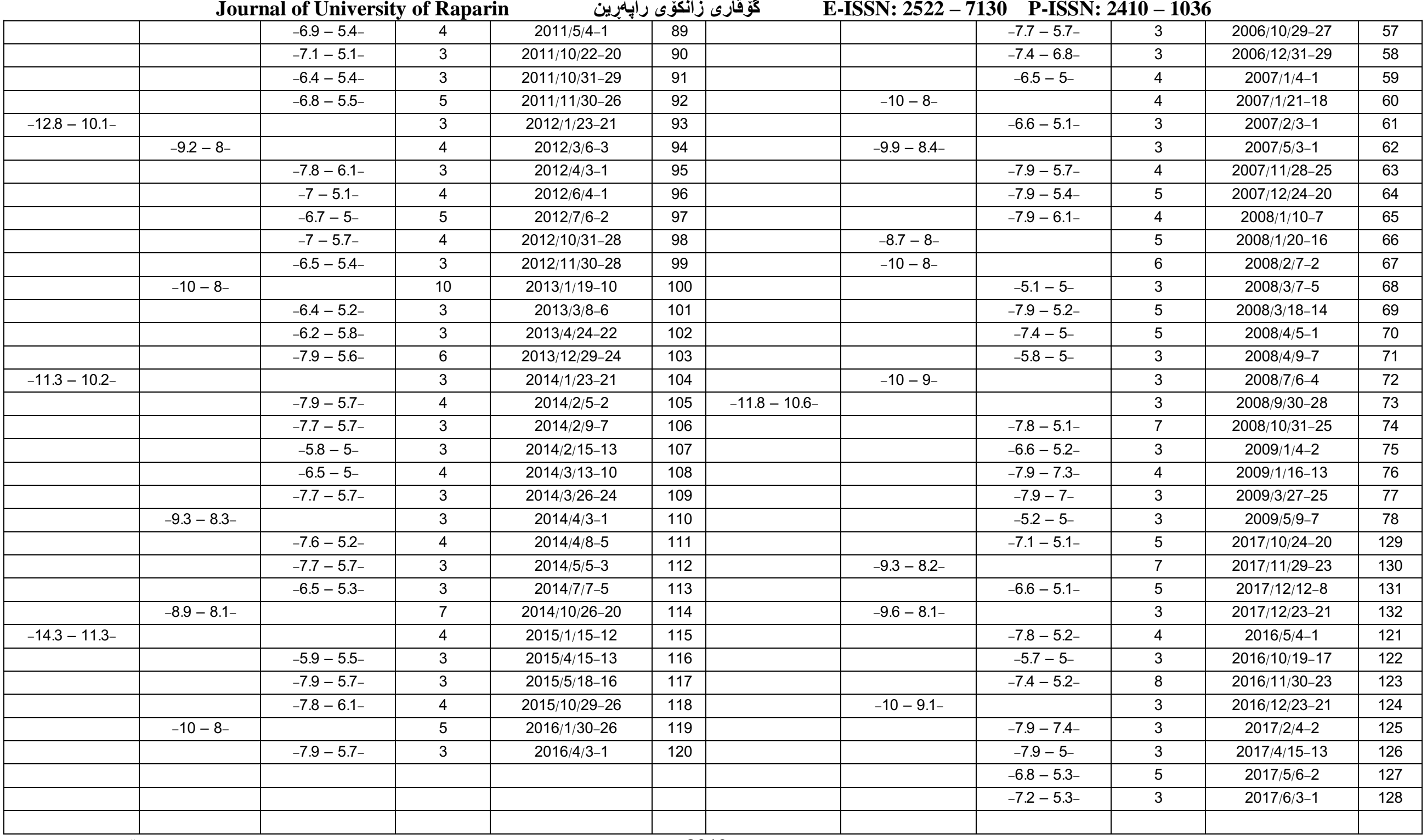

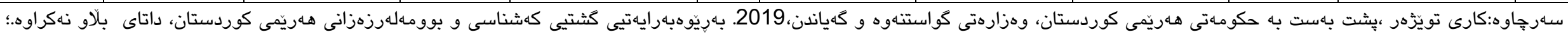

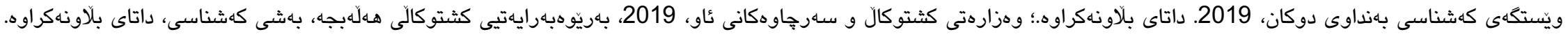

